ks. Andrzej Bruździński

\title{
Bielany - ulubione miejsce Krakowa. Związki bielańskich kamedułów z Krakowem w okresie staropolskim
}

Na początku XVII wieku pojawili się pejzażu krakowskim biali mnisi, kameduli (Congregatio Eremitarum Camaldulensium Montis Coronae). Sprowadził ich z eremu Montis Coronae koło Ankony i odpowiednio uposażył marszałek nadworny króla Zygmunta III Wazy Mikołaj Wolski h. Półkozic (1555-1630), pan na Podhajcach - „człowiek wielkiey pobożności”'. Był to wyraz jego ekspiacji za niezasłużone pobieranie (w latach 1589-1600) dochodów z poznańskiej komandorii maltańczyków². Starania Wolskiego o sprowadzenie tychże mnichów u Stolicy Apostolskiej wspierał sam król Zygmunt III, pisząc listy polecające do kardynałów ${ }^{3}$. Mnisi ci, nie bez racji, popierani byli przez papieży i Stolicę Apostolską, gdyż wpisywali się od początku swego istnienia w dzieło odnowy Kościoła, opracowując już w 1513 roku Libellus ad Leonem Decimum - program całkowitej reformy kościelnej. Dlatego ci nowi pustelnicy stali się osobistościami szanowanymi w Kościele 4 . Fundację kra-

${ }^{1}$ P. H. Pruszcz, Kleynoty Stołecznego Miasta Krakowa albo Kościoły, y co w nich iest widzenia godnego y zacnego. przez [...] krotko opisanie, Powtornie zaś z pilnościa przeyźrzane, y do druku $z$ additamentem nowych Kośćiołów y Relikwii S. Podane, Kraków 1745, W Drukarni Akademickiey, s. 181; A. Małkiewicz, Zespół architektoniczny na Bielanach pod Krakowem (1605-1630), [w:] Zeszyty Naukowe Uniwersytetu Jagiellońskiego, nr 45. Prace z historii sztuki. z. 1. Kraków 1962, s. 144.

${ }^{2}$ J. Baranowski, Zakon Maltański w Polsce w XVI i XVII wieku, [w:] Zakon Maltański w Polsce, red. S. K. Kuczyński, Warszawa 2000, s. 47; Z zamierzchłej przeszłości Parafji św. Jana i Komandorji, Poznań 1929, s. 29-30.

${ }^{3}$ P. T. Lugano, La Congregazione camaldolese degli Eremiti di Montecorona. Dalle origini ai nostri tempi. Con una introduzione sulla vita eremitica prima e dopo san Romualdo, [w:] Monografie di storia benedettina, T. 1, Frascati 1908, s. 328-337; A. Grabowski, Przedmieścia i okolice Krakowa. Wypisy z dzieł. Wyd. A. Wawryszczuk. Kraków 2007, s. 94.

${ }^{4}$ E. Sastre Santos CMF, La vita religiosa nella storia della Chiesa e della società, Milano 1997, s. 565; G. Alberigo, Sul Libellus ad Leonem X degli eremiti camaldolesi: Vicenzo Querini e Tommaso 
kowską u jej początków popierał kardynał a secretis Aldobrandini, pisząc w roku 1603 do biskupa diecezjalnego krakowskiego Bernarda Maciejowskiego, iż zakonnicy ci „promienieją niezmierną jasnością najświetniejszego przykładu, a tym blaskiem zachwycone dusze wiernych rwą się ku niebiosom"5. Dzieło to wspomógł także, ulegając namowom żony, inny ówczesny wielki magnat, kasztelan wojnicki Sebastian hrabia Lubomirski h. Drużyna (ok. 1546-1613), pan na Wiśniczu, ofiarując eremitom „villam suam Bielany et Montem Bieleńska Srebrna dictam”. Na czele kilkunastoosobowej grupy młodych zakonników sprowadzonych w 1605 roku z ufundowanego przez błogosławionego Pawła (czyli Tomasza Giustinianiego, 1478-1528) eremu Montis Coronae stał superior o. Hieronim z Perugii, zwany u nas Hieronimem z Perużu7. Po 5 latach od przybycia na tę fundację biali mnisi $\mathrm{z}$ długimi brodami z Eremi Montis Argentini wpisali się na trwałe w historię i życie mieszkańców Krakowa, gdyż wówczas już na stałe osiedlili się na Srebrnej Górze w południowo-zachodniej części pięknego Lasku Wolskiego ${ }^{8}$. Marszałek Wolski nie tylko wybudował klasztor kamedulski, ale otaczał go cały czas swoją opieką, a wyrazem tego było zabieganie o papieską aprobatę dla niego, jak i inne potrzebne przywileje podczas swego poselstwa do Rzymu w 1610 roku9 $^{9}$

W 1616 roku przedstawiając intencje fundatora pełnego przepychu klasztoru kamedułów rajca krakowski Ludwik Kromer (†1621 lub 1622) zanotował, iż „pragnieniem ustawicznego bogomodlstwa za Koronę wzbudzony ku Panu

Giustiniani, [w:] Collection de l'École française de Rome, N. 330: Humanisme et Eglise en Italie et en France méridionale (XVe siècle - milieu du XVI e siècle), red. P. Gilli, Rome 2004, s. 349-359.

${ }^{5}$ Monografje zakonów, „Przegląd Katolicki”, R. [4]: 1866, nr 16, s. 247.

${ }^{6}$ Biblioteka XX. Czartoryskich w Krakowie (dalej: BCzart.), rkps 2894 V: Kameduli na Bielanach, 1597-1806. Zbiór aktów dotyczących głównie spraw majątkowych klasztoru, przeważnie z XVII w., s. 255-262; S. Starowolski, Monvmenta Sarmatarvm. Viam vniuersae carnis ingressorum Simone Starovolscio [...] collectore, Cracoviae 1655, in Officina Viduae [et] Haeredum Francisci Caesarij, s. 212-213; J. Długosz, Lubomirski Sebastian h. Szreniawa (ok. 1546-1613), [w:] Polski Słownik Biograficzny, t. 18, red. E. Rostworowski, Wrocław 1973, s. 40-42. Nie jest więc prawdą, iż góra ta od białych kamedulskich habitów nosi nazwę „Bielany”, a od uczty u Wolskiego, na której miał podarować srebrną zastawę Lubomirskiemu, nazywa się „Srebrna”.

${ }^{7}$ L. Zarewicz, Zakon kamedułów, jego fundacye i dziejowe wspomnienia w Polsce i na Litwie. Przeważnie według źródeł rękopiśmiennych archiwu OO. Kamedułów w Bielanach przy Krakowie skreślił Ludwik Zarewicz, Kraków 1871, s. 22-23, 103; J. Kracik, Marszałek funduje kamedułów, „Folia Historica Cracoviensia”, vol. 11, 2005, s. 39.

${ }^{8}$ R. Witkowski, Uwag kilka o eremach kamedulskich w Rzeczypospolitej szlacheckiej, [w:] Historia bliższa i dalsza. Polityka, społeczeństwo, wojskowość. Studia z historii powszechnej i Polski, red. S. Kowal, G. Kucharski, M. Walczak, Poznań - Kalisz 2001, s. 190.

${ }_{9}$ W. Tygielski, Marszałka Mikołaja Wolskiego poselstwo do Rzymu (1609-1610), „Odrodzenie i Reformacja w Polsce", t. 43, 1999, s. 78. 
Bogu Iaśnie Wielmożny Iego M. P. Mikołay Wolski z Podhaiec, Wielki Marszałek Koronny zupełney doskonałości Senator, Kościół y Klasztor pozorny, wielkim kosztem na Górze Srebrney, Złotym Oycom Pustelnikom, Zakonnikom ś. Romualda, którzy się zowią Camaldulenses, na ustawiczną bogomyślność oddanym, tuż nad Krakowem założyć raczył"10. Kilka lat później Szymon Starowolski podobnie interpretował czyn marszałka fundującego pustelnię, widząc w nim wyraz pobożności i miłości ojczyzny ${ }^{11}$, tak to też widzieli sami kameduli, według których płynęło to „religione in Deum, pietate in Diuos, obseruantia in Ecclesiam, fide in regum et regnum"12.

\section{Położenie eremu bielańskiego}

Usytuowanie tego eremu bielańskiego przedstawił słynny XVII-wieczny kanonik krakowski Szymon Starowolski (1588-1656), opisując go jako położony „na zachód od miasta, o jedną milę, [...] na górze bardzo wyniosłej, zwanej Srebrną [...] przez wspomnianego [...] Mikołaja Wolskiego, wielkim sumptem zbudowany, gdzie [...] wszystko jest uczynione dokładnie według proporcji geometrycznych w sztuce budowlanej obserwowanych"13. Nic więc dziwnego, że fundator, który był „znany ze swej wyniosłej postawy” ${ }^{14}$, chciał wznieść wielkie dzieło, zostawił ponadto spory testamentalny zapis dla kościoła bielańskiego „postawionego lubo jeszcze nie skończonego”, został po śmierci w 1630 roku pogrzebany w rozległych podziemiach tego kościoła w habicie kamedulskim ${ }^{15}$. Z kolei Albrycht Stanisław

${ }^{10}$ L. Kremer, Przedmowa, [w:] L. Lessius SI, Narada którey wiary trzymać się mamy [...]. Przełożona z łacińskiego na język polski przez Ludwika Kremera rayce krakowskiego, Cracoviae 1616, sumptius Burchardi Kuikij, k. (?) ${ }_{3} \mathrm{v}$.

${ }^{11}$ S. Starowolski, Simonis Starovolsci Camaldvla Argentini sive De Laudibus inclyti Camaldulensis Ordinis, FF. Eremitarum, propè Cracouiam, in monte Argentini. Orationes III, Cracoviae 1623, In Officina Typogr. Matthiae Andreouiensis, k. $\mathrm{C}_{2}$.

${ }^{12}$ S. Starowolski, Monvmenta Sarmatarvm..., dz. cyt., s. 212.

${ }^{13}$ S. Starowolski, Polska albo opisanie położenia Królestwa Polskiego, przeł. A. Piskadło, Kraków 1976, s. 77.

${ }^{14}$ [L. Bevilacqua], Relacja z podróży pana margrabiego Bevilacqua, odbytej w związku z poselstwem do Krakowa [1609], [w:] W. Tygielski, Dyplomacja - informacja - propaganda. Podróż Luigiego Bevilacqua, posła toskańskiego, na dwory europejskie w 1609 r., Warszawa 2000, s. 91.

${ }^{15}$ J. Wielewicki SI, Dziennik spraw domu zakonnego OO. Jezuitów u św. Barbary w Krakowie, t. 5: 1630-1639, Kraków 1999, s. 50-51; BCzart., rkps 1821 IV: Testament Mikołaja Wolskiego, s. 9, 17-18, $34,49$. 
Radziwiłł (1593-1656) napisał o tej fundacji kilka lat później: „gmach godny króla, nie szlachcica. Niech mu Bóg będzie wieczną nagrodą. [...] Rzecz jest godna zobaczenia i może równać się z zagranicznymi budowlami” ${ }^{16}$. „Budowa trwała lat dwadzieścia, ukończona w roku 1642. Piękne jest do niej z białego marmuru wejście, wewnątrz zaś jest ośm kaplic wyłożonych marmurem czarnym dębnickim, pięknie odbijającym się od białego tła świątyni” ${ }^{17}$. Z czasem kościół ten stał się przełomowy w architekturze baroku w Polsce, a nawet Europie, natomiast erem ten stał się czwartym klasztorem w zakonie co do znaczenia i starszeństwa ${ }^{18}$.

Znakomita budowla, będąca jedną z najpiękniejszych pereł baroku, wzorowana na świątyniach północnych Włoch, znajdowała się we wspaniałej przyrodniczo okolicy. Sama przyroda i jej tajemnicza natura skłaniała człowieka do medytacji, gwarantując samotność i ciszę sprzyjającą kontemplacji. Opisując położenie bielańskiego klasztoru dziewiętnastowieczny księgarz i historyk krakowski Ambroży Grabowski (1782-1868) napisał: „około samej góry płynie Wisła, dodając przyjemności okolicy tej już siebie pięknej. Na wierzchu góry powietrze lekkie i czyste, woniejące balsamem przez drzewa i rośliny uronionym, gwar ptactwa i rozległy widok nad przestrzenią, przejmują zachwycającą rozkoszą i do zmysłów miłośnika natury upojonego pięknościami jej orzeźwienie zanoszą. Niegdyś góra srebrna pokryta była staremi dębami majestatycznej wielkości”' ${ }^{19}$. Wszystko to umożliwiało realizację kamedulskiego charyzmatu - triplex bonum - a więc samotności, wspólnoty i evangelium paganorum ${ }^{20}$.

16 A. S. Radziwiłł, Pamiętnik o dziejach w Polsce, t. 1: 1632-1636, przeł., oprac. A. Przyboś, R. Żelewski, Warszawa 1980, s. 294.

${ }^{17}$ F. M. Sobieszczański, Wiadomości historyczne o sztukach pięknych $w$ dawnej Polsce zawierające opis dziejów i zabytków budownictwa, rzeźby, snycerstwa, malarstwa i rytownictwa, z krótka wzmiankq o życiu i dziełach znakomitszych artystów krajowych, lub $w$ Polsce zamieszkałych, t. 2, Warszawa 1849 , s. 39.

${ }^{18}$ Reguła św. Benedykta i Konstytucje Zgromadzenia Kamedułów-Pustelników Góry Koronnej. Przejrzane i potwierdzone przez Ojca Św. Klemensa IX, Kraków 1912, s. 274; K. Guttmejer, Siedemnastowieczne fundacje dla kamedułów w Polsce, [w:] Studia nad sztuka renesansu i baroku, t. 8: Fundator i dzieło w sztuce nowożytnej, cz. 3, red. J. Lileyko, I. Rolska-Boruch, Lublin 2007, s. 78; P. Czartoryski-Sziler, Kameduli ze Srebrnej Góry, „Nasz Dziennik”, R. [9]: 2006, nr 146 z dn. 24-25 VI, s. 30 .

${ }^{19}$ A. Grabowski, Przedmieścia i okolice Krakowa..., dz. cyt., s. 95.

${ }^{20}$ M. Karpowicz, Andrea Spezza - architekt nadworny Lubomirskich, „Barok”, R. 9, 2002, nr 1/2, s. 10-16; J. Wang OSBCam, „Triplex bonum” w życiu Pięciu Braci Męczenników. Charyzmat św. Romualda i tradycja monastyczna, [w:] Męczennicy z Międzyrzecza 1003-2003. Materiały z sympozjów: 9-10.11.2001, 8-9.11.2002, red. R. Tomczak, Paradyż - Zielona Góra 2003, s. 139. 


\section{Wpływ duchowości kamedulskiej}

Specyficzna duchowość kamedulska, w której zbiegają się humanizm i duchowość reformistyczna, charakteryzuje się kontemplacją świętego człowieczeństwa Jezusa Chrystusa. Przeżywana była w duchu typowo benedyktyńskim, ale także pod wpływem współczesnej devotio moderna ${ }^{21}$. Przekazywana była postronnym m.in. przez propagowanie charakterystycznej pobożności kamedulskiej, której wyrazem była koronka kamedulska ku czci męki i śmierci Chrystusa, liczbą paciorków nawiązująca do lat ziemskiego życia Jezusa i Jego pięciu ran. Koronka ułożona została przed 1516 rokiem przez rekluza z Camaldoli, Michele Pini z Florencji, zwanego błogosławionym (ok. 1450-1522) 22 $^{2}$ Była ona obdarzona wieloma papieskimi odpustami, począwszy od papieża Leona X (1475-1521), który dokonał tego brewem Nuper nobis fide $\mathrm{z}$ dnia 18 lutego $1516 \mathrm{roku}^{23}$. Pomimo iż wydano ją po raz pierwszy w Polsce w 1658 roku w krakowskiej oficynie typograficznej Franciszka Cezarego ${ }^{24}$, to znana była w Krakowie znacznie wcześniej. W roku 1627, w krakowskiej oficynie Bartłomieja Kwaśniowskiego, kanonik od pokuty - od św. Marka - ks. Just Pomorski h. Gwiazdy († po 1640$)^{25}$ wydał podstawowe teksty Bractwa św. Zofii, a wśród przepisanych członkom modlitw znajdowała się wspomniana kamedulska koron$\mathrm{ka}^{26}$. Powtórzone to zostało, gdy w roku 1683 za zezwoleniem papieża Innocente-

${ }^{21}$ R. Vanderbroucke, La spiritualità del Medioevo (XII-XVI secolo). Nuovi ambienti e problemi. [w:] Storia della spiritualità, t. 4/B. Bologna 1991, s. 413; E. Sastre Santos CMF, La vita religiosa nella..., dz. cyt., s. 565-566.

${ }^{22}$ C. Somigli, Pini Michele, eremita, beato, [w:] Bibliotheca sanctorum, t. 10. Roma 1969, s. 874-875; P. Robert OSBCam, Camaldules (Orde des), [w:] Dictionnaire de spiritualité ascétique et mystique. Doctrine et histoire, red. C. Baumgartner SI, M. Viller, A. Rayez, t. 2. Paris 1953, kol. 57.

${ }^{23}$ Sommario cronologico dei documenti pontifici riguardanti la Congregazione Eremitica Camaldolese di Monte Corona (1515-1908), [Frascati] 1908, nr 2, s. 2.

${ }^{24}$ Koronka żywota przenayświętszego Jezusa Chrystusa Zbawiciela naszego od Pasterzów naywyższych $z$ dawna uprzywileiowana y odpustami wielkiemi nadana a teraz sposobami odprawowania według zwyczaiu OO. Kamedułów nowo wydana, Kraków 1658, u Franciszka Cezarego; Koronka Kamedulska ku czci Pana Jezusa, jej początek, znaczenie i odpusty nadane od Stolicy Apostolskiej, przeł. X. Wacław [Nowakowski] Kapucyn, Kraków 1901.

${ }^{25}$ T. Święcki, Historyczne pamiątki znamienitych rodzin i osób dawnej Polski, t. 1, Warszawa 1858, s. 246; W. A. Maciejowski, Piśmiennictwo polskie od czasów najdawniejszych aż do roku 1830. Z rękopisów i druków zebrawszy, w obrazie literatury polskiej historycznie skreślonym, t. 3. Warszawa 1852, s. 127.

${ }^{26}$ Bractwo Zophiey S. w Krakowie $z$ dawna fondowane, y wielkimi Indulgentiami od Stolice Apostolskiey ubogacone, y przywileiami robowane. A poważnościa ś. pamięci Jeo Mci X. Piotra Tylickiego Biskupa Krak. także Jego Mci X. Franciszka Synomety, na on czas Legata Apostolskiego confirmowane. Teraz znowu do druku podane za powodem zakonników Fratrum de Poenitentia, 
go XI wprowadzono to bractwo do parafii w miasteczku Sączów w Księstwie Siewierskim. Wówczas to staraniem miejscowego plebana ks. Szymona Stankiewicza wydano książeczkę bracką wraz z modlitwami, wśród których znajdowała się także koronka kamedulska ${ }^{27}$. Bibliografia polska Karola Estreichera odnotowuje jeszcze dwa kolejne wydania tej koronki w XVIII wieku ${ }^{28}$. Z tej to przyczyny Pruszcz napisał, iż kameduli „ubogaceni odpustami [...] osobliwie na Koronkę Pana Jezusa maią od różnych Oyców Swiętych nadane Indulgencye"29.

Kameduli krakowscy propagowali także kult swego ojca duchowego, św. Romualda (952-1027). Kameduła bielański o. Benedykt (Stefan) Dzierżek († 1709) wydał w roku swojej śmierci - 1709 - w drukarni Franciszka Cezarego nowennę do św. Romualda opata wraz z Małym Oficjum poświęconym temu świętemu. Autor dedykował to dzieło kanonikowi krakowskiemu Krzysztofowi Andrzejowi Janowi Szembekowi h. Dwie Kozy (1680-1740), późniejszemu biskupowi przemyskiemu i warmińskiemu ${ }^{30}$.

\section{Powołania zakonne}

Życie eremickie dla mnichów kongregacji Monte Corona przeżywającej regułę benedyktyńską według wskazań bł. Pawła Giustinianiego nie było sprawą

SS. Martyrum, S. Mariae de Metri, de Urbe, sub regula S. Augustini militantium y za staraniem $X$. Justa Pomorskiego rectora tegoż Bractwa, y P. Walentego Gedzickiego Wiceger. Brackiego, Kraków 1627, u Bartło[mieja] Kwaśniowskiego, k. $\mathrm{C}_{2}-\mathrm{C}_{5} \mathrm{v}$.

${ }^{27}$ S. Stankiewicz, Bractwo Zofii świętey, $z$ dawna w Koronie Polskiey, na rożnych mieyscach, osobliwym nabożeństwem, $y$ Wielkimi Odpustami slynace; a teraz za dozwoleniem S. Stolice Apostolskiey, y za powaga Urzędu Duchownego, przy kościele Sączowskim przez W. X. Szymona Stankiewicza, plebana Sączowskiego Fundowane, y iuż z łaski Bożey, szczęśliwie wprowadzone; a dla lepszey Informacyi, Braci y Sióstr Bractwa tego, z powinnościami, Nabożeństwy, y z Odpustami swemi, za dozwoleniem Starszych, do Druku podane, Kraków 1685, w Drukarni Akademickiey, s. 22-39.

${ }^{28}$ K. Estreicher, Bibliografia polska, t. 20. Kraków 1905, s. 99-100.

29 P. H. Pruszcz, Kleynoty Stołecznego Miasta Krakowa..., dz. cyt., s. 180-181.

${ }^{30}$ [S. Dzierżek], Novendium seu novem dierum exercitia, ad honorem gloriosi patriarchae S. Romualdi Abbatis. Pro novem Martis diebus, prodigiosam eius, ad inclytam Fabrianensem civitatem, translationem praecedentibus, quae die 7 Februari occurit. Ex quibus exercitijs quinque hoc + signo adnotata, devotiis assumet pro totidem ferijs tertijs ad diem felicis S. Patris transitus in coelum, se extendentibus, cujus dies Anniversaria 19. Iunij recolitur. Inserta etiam est compendiose vita ejusdem Patris, pro majori devotorum excitatione; tum Parvum ejus Officium, et Responsorium [...], Cracoviae 1709, Typis Francisci Cezary. 
prywatną, ale także apostolskim głoszeniem królestwa Bożego poprzez ciche przypominanie człowiekowi o przemijalności czasu i braku tutaj, na ziemi, trwałego miasta ${ }^{31}$. Najlepszym świadectwem oceny postawy zakonnej kamedułów i ich wierności regule były i są miejscowe, krakowskie powołania. Pierwszym z nich był brat Mateusz z Krakowa, czyli Zygmunt Brynner (1595-1687), który złożył profesję 29 września 1617 roku, on też był pierwszym polskim przeorem na Srebrnej Górze ${ }^{32}$ oraz pierwszym polskim wizytatorem generalnym przy przełożonym generalnym na Monte Corona w latach 1633-1634 oraz 1641-1643 ${ }^{33}$. Następnego roku profesję złożył brat Ambroży, czyli Mikołaj Delpace (†1681), w roku 1622 natomiast brat Bonifacy, czyli Aleksander Sławiec († 1676), syn Adama $^{34}$. W tym samym roku profesję kamedulską na ręce przeora o. Alberta z Padwy złożył Michał Fricowski ( $†$ 1657) syn krakowskiego obywatela i kupca Stefana, który otrzymał imię zakonne Anastazy. Z jego zachowanego testamentu napisanego przed złożeniem zakonnej profesji wiemy, że posiadał on doktorat z filozofii i obojga praw. Jest on autorem pozostałego w rękopisie dzieła zatytułowanego Aurea silva sive Apophtegmata exemplorum ${ }^{35}$. W roku 1625 profesję złożył brat Wojciech, czyli Stanisław Szober vel Schober $(\dagger 1657)$, syn pochodzącego ze Lwówka rajcy krakowskiego Krzysztofa († 1630), doktor obojga praw, pisarz i tłumacz dzieł teologicznych, określany jako vir doctissimus et iurista maximus $^{36}$. W 1661 roku profesję złożył brat Paweł, w świecie ks. Władysław

${ }^{31}$ L. Mezzadri, Duchowość I połowy XVI wieku (1517-1545), [w:] Historia duchowości, t. 5: Duchowość chrześcijańska czasów nowożytnych, przeł. E. Dobrzecka OSsR, Kraków 2005, s. 23.

${ }^{32}$ BCzart. rkps 1822 I: Liber professorum Montis Argentini Eremitarum Camalduliensium, s. 23; P. Sczaniecki OSB, Kameduli, [w:] Zakony benedyktyńskie w Polsce. Krótka historia, [Kraków] 1981, s. 109.

${ }^{33}$ P. T. Lugano, La Congregazione camaldolese degli Eremiti di Montecorona..., dz. cyt., s. $511-512$.

${ }^{34}$ BCzart., rkps 1822 I, s. 25, 33; tamże, rkps 2894 V, s. 231-232.

${ }^{35}$ Tamże, rkps 1822 I, s. 34; tamże, rkps 1820 IV: Akta do spraw majątkowych Mikołaja Wolskiego i kamedułów na Bielanach pod Krakowem, s. 131-132; Album studiosorum Universitatis Cracoviensis, T. 4: Continens nomina studiosorum ab anno 1607 ad annum 1642, wyd. G. Zathey, H. Barycz, Cracoviae 1950, s. 51.

${ }^{36}$ Stanisław Szober był synem rajcy krakowskiego Krzysztofa i jego żony Anny. Studiował w Uniwersytecie Krakowskim, gdzie w 1614 r. zdobył bakalaureat sztuk wyzwolonych, a w następnym roku otrzymał doktorat z filozofii. W 1618 r. został bakałarzem prawa. W 1619 r. przebywał w Padwie, gdzie wpisał się do metryki nacji polskiej. Doktorat obojga praw uzyskał w dniu 5 VII 1621 r. w Rzymie. Statuta nec non liber promotionum philosophorum Ordinis in Universitate studiorum Jagellonica, ab anno 1402 ad annum 1849, wyd. J. Muczkowski, [w:] Zabytki z Dziejów Oświaty 
Zygmunt Mitkowski (1619-1661), doktor medycyny i prebendarz w kościele Mariackim, zamieszkały dawniej przy ulicy Szewskiej w Krakowie, który w kilka miesięcy po tym fakcie zmarł w klasztorze bielańskim († 9 września) ${ }^{37}$.

Kandydaci do krakowskiego eremu pochodzili z różnych rejonów Polski, od Bytomia i Łososiny, przez Szadek i Łęczycę, po Gdańsk, ale byli też i obcokrajowcy. Pierwszą profesję kamedulską jeszcze w Bodzowie k. Tyńca złożył w dniu 29 czerwca 1606 roku brat Stanisław, czyli Niccolò Cappellaro ( $†$ 1645), syn Angela z diecezji padewskiej, w roku 1624 brat Stefan, czyli Wawrzyniec Grison $(\dagger 1682)$ ze Szwajcarii, czy w 1635 roku Niemiec, brat Józef z Wrocławia ${ }^{38}$. Na Srebrnej Górze jako pierwszy Polak składał profesję w 1611 roku brat Florian z Warzyc koło Jasła ( $†$ 1651), który w latach 40. XVII wieku będzie kilkakrotnym przeorem klasztoru ${ }^{39}$. W pierwszym półwieczu istnienia klasztoru, w okresie do roku 1660, w eremie tym profesje zakonne złożyło 52 mnichów, a więc statystycznie niemalże jeden co rok. Łącznie w eremie bielańskim w interesującym nas okresie dwóch stuleci, tzn. do roku 1800, profesję złożyło 394 mnichów, w tym 273 przyszłych kapłanów i 121 braci konwersów, czyli statystycznie prawie dwie profesje na rok. Powołań kamedulskich z Krakowa wraz z okolicznymi jurydykami było w tym czasie łącznie 56; i odpowiednio 43 kapłanów i 13 bra$\mathrm{ci}^{40}$. W Krakowie spora część bielańskich mnichów-kapłanów otrzymała niższe czy wyższe święcenia kapłańskie z rąk biskupów krakowskich ${ }^{41}$. Erem bielański,

i Sztuk Pięknych, t. 1, Cracoviae 1849, s. 276; Archiwum nacji polskiej w Uniwersytecie Padewskim, t. 1: Metryka nacji polskiej w Uniwersytecie Padewskim (1592-1745), Wrocław 1971, s. 397; J. Bieniarzówna, Mieszczaństwo krakowskie XVII w. Z badań nad struktura społeczna miasta, Kraków 1969, s. 39; E. Ozorowski bp, Szober Wojciech ( +1664$)$, kameduła, autor dysertacji z prawa kanonicznego, [w:] Słownik polskich teologów katolickich, t. 4, red. H. E. Wyczawski OFM, Warszawa 1983, s. 279; Archiwum Kamedułów w Krakowie, rkps Professio Fratrum 1577-1670, według daty.

37 J. Lachs, Kronika lekarzy krakowskich XVII wieku, Poznań 1929, s. 29-30; M. Czapińska, Mitkowski Władysław, imię zakonne Paweł (1619-1661), [w:] Polski Słownik Biograficzny, t. 21, red. E. Rostworowski, Wrocław 1976, s. 384; Archiwum Kamedułów w Krakowie, rkps Professio Fratrum 1577-1670, według daty.

${ }^{38}$ BCzart., rkps 1822 I, s. 3-4, 5, 50.

${ }^{39}$ Tamże, s. 9; wieś Warzyce - położona obecnie w gminie Jasło, w powiecie jasielskim, w województwie podkarpackim.

${ }^{40}$ [S. Andrychowicz], Series reverendorum patrum et fratrum eremitarum Camedulensium congregationis Montis Coronae tam eremi Montis Argentini supra Cracoviam in Polonia quam eremi Montis Pacis supra Coronam in Lithuania Professorum vivorum et vita defunctorum conscripta, Viennae Austriae [ok. 1760], ex typ. Gheleniana, s. 3-28.

${ }^{41}$ Fakt otrzymania święceń kapłańskich jakiegokolwiek stopnia w Krakowie odnotowany został w Aneksie. 
mimo iż nie był to najbogatszy klasztor kamedulski w Polsce, był najliczniejszą polską wspólnotą uczniów św. Romualda ${ }^{42}$.

Pierwszy zmarły na Bielanach kameduła odszedł do Pana w roku 1617. Był nim pierwszy przeor bielańskiego eremu, o. Barnaba Włoch. Kolejnym był zmarły w 1622. ojciec Manswet (w świecie Paweł Lutomirski) pochodzący z Szadku, który przed wstąpieniem do klasztoru był mansjonarzem w Łęczycy, a profesję zakonną złożył na Bielanach w dniu 1 listopada 1615 roku $^{43}$. Kolejny pogrzeb na Srebrnej Górze odbył się w sierpniu 1635 roku. Pochowano wówczas, pochodzącego z Biecza, księdza Michała Bieczkiego syna Pawła, który profesję złożył w klasztorze Monte Rua w dniu 29 lipca 1603.

\section{Znani kameduli krakowscy}

Kamedulska ucieczka w samotność była także i jest profetycznym, choć cichym apostolskim przepowiadaniem. Pustelnik kameduła realizuje w swoim życiu słowa świętego Pawła: „Vita vestra est abscondita cum Christo in Deo” (Kol 3, 3), ale idąc za Chrystusem wykorzystuje w tym swoje talenty i uzdolnienia. W klasztorze bielańskim zasłynął w ten sposób o. Firmian, w świecie Jan Gierlicki syn Walentego z Krosna. Wstąpił do kamedułów we włoskim eremie S. Mariae Angelorum w Nola pod Neapolem, gdzie złożył profesję zakonną 29 września 1617 roku. W 1621 roku wraz grupą kamedułów został przysłany do Krakowa, gdzie po pewnym czasie został przeorem. Przed wstąpieniem do klasztoru otrzymał także dobre wykształcenie muzyczne - arte musice valde clarus in statu clericali. Był znanym ówczesnym kompozytorem, który nawet miał wydawać w Gdańsku drukiem swoje muzyczne utwory. Nie są one jednak znane. Jak wskazują rachunki klasztorne, na różne kościelne uroczystości sprowadzał z Krakowa na Bielany muzyków, mimo iż było to wbrew konstytucjom zakonnym. Określany był przez współczesnych musicus celeberrimus. Był

${ }^{42}$ J. Kłoczowski, Zakony męskie w Polsce XVI-XVIII wieku, [w:] Kościół w Polsce, t. 2: Wieki XVI-XVIII, red. J. Kłoczowski, Kraków 1969, s. 526.

${ }^{43}$ L. Zarewicz, Zakon kamedułów..., dz. cyt., s. 104-105; Monastica Polonorum. Fontes et studia, red. A. M. Wyrwa, R. Witkowski, t. 1: Wizytacje klasztoru cysterek w Owińskach. Nekrolog klasztoru cystersów w Paradyżu. Katalogi monastyczne, Warszawa 2009, s. 212. 
jednym z pierwszych Polaków, którzy sprawowali funkcje przeora w klasztorze bielańskim. Zmarł w tymże eremie w 1660 roku $^{44}$.

Jak wspomniano, piszącym kamedułą był o. Wojciech Szober, który był autorem dysertacji z prawa kanonicznego napisanej przed wstąpieniem do klaszto$\mathrm{ru}^{45}$. W klasztorze z kolei przetłumaczył na język polski w roku 1626 Septem tubae ad poenitentiam reformaty Bartolommea Cambi da Saluzzo (1557-1617) ${ }^{46}$, a dla własnej pobożności przełożył zbiór modlitw Preces et contemplationes hymni varii collectae. Dzieła te pozostały w rękopisach i są przechowywane w bibliotece klasztoru bielańskiego.

Tłumaczeniem zajmował się również świątobliwy o. Franciszek, czyli Krzysztof Wilga (1623-1698), który profesję złożył w 1643 roku, był też pierwszym rektorem najbogatszego polskiego eremu kamedulskiego na Wigrach, kilkukrotnym krakowskim przeorem i polskim wikariuszem generalnym. Przetłumaczył w roku 1659 na język łaciński skrót dzieła kameduły z Monte Corona Agostina da Napoli Il prelato religioso, wydanego pod pseudonimem (anagramem) Giovanni Santo ${ }^{47}$. Ojciec Franciszek Wilga nazywany w źródłach „perłą kamedulską" przełożył także w 1655 roku na język polski modlitewnik zakonny Oratorium religiosum. Obydwie te prace pozostały w rękopisach i są przechowywane w bielańskiej bibliotece.

Kolejnym piszącym mnichem w klasztorze bielańskim był jego przeor, pochodzący z Warszawy „pater observantissimus” Serafin Andrychowicz (1724-1772). W pracy wydanej w Wiedniu w 1760 roku, a dedykowanej ówczesnemu majorowi, czyli generałowi kongregacji Montis Coronae (w latach 1757-1761) don Parisio da Brescia (Pietro Tosini) ${ }^{48}$, który przybywał do Polski z wizytacją,

${ }^{44}$ J. W. Reiss, Najpiękniejsza ze wszystkich jest muzyka polska. Szkic historycznego rozwoju na tle przeobrażeń społecznych, Kraków 1946, s. 72; A. Chybiński, Słownik muzyków dawnej Polski do roku 1800. Z arkuszy dodawanych do „Kwartalnika Muzycznego” 1948/49, Kraków 1949, s. 36; L. Zarewicz, Zakon kamedułów..., dz. cyt., s. 124-135.

${ }^{45} \mathrm{~W}$. Szober, Quaestio de immunitate et libertate ecclesiastica [...] quam [...] pro ingressu ad primam lauream in U. J. ad disputandum proponet [...], Cracoviae 1618, Typis Francisci Caesarii, k. nlb. 8.

${ }^{46}$ Bartholomaei Saluthii [...], Septem tubae excitantes peccatorem ad poenitentiam. Opusculum ad omnium hominum peccatis obstrictorum salutis longe utiliss. Nunc recens ex italico in latinum conversum per M. Henricum Stampsium, Friburgi Brisgoviae 1620, apud Ioannem Strasserum sumptib. Henrici Dulcken bibliop.

${ }^{47}$ G. Santo, Il prelato religioso opera del padre d. Gio. Santo da Napoli, dell'Ordine di s. Benedetto. Napoli 1645, per Honofrio Sauio, a spese di Francesco Balsamo; G. Melzi, Dizionario di opere anonime e pseudonime di scrittori italiani. O come che sia aventi relazione all'Italia, t. 3, Milano 1859, s. 25.

${ }^{48}$ P. T. Lugano, La Congregazione camaldolese degli Eremiti di Montecorona..., dz. cyt., s. 518. 
podjął się o. Serafin jednej z pierwszych prób napisania krótkiej historii wszystkich polskich klasztorów kamedulskich. W tym opracowaniu pisanym zapewne w pośpiechu, dlatego nie wolnym od błędów, zaprezentował skrótowo wszystkie siedem polskich eremów i ich fundatorów. W drugiej części natomiast wyliczył wszystkich mnichów kamedulskich, którzy w ciągu historii mieszkali w eremach bielańskim i Montis Pacis w Pożajściu na Litwie ${ }^{49}$.

\section{Kontakty eremitów ze „światem” - dobrodzieje}

Innym znakiem pochlebnej opinii o kamedułach w ich wiernym pójściu za Chrystusem były zapisy testamentowe czynione na klasztor bielański. Przed 19 października 1633 roku rajca miejski Krzysztof Szober († 1633) zapisał bielańskim zakonnikom, wśród których był jego brat, niebagatelną sumę 500 złotych „które mają być na widerkaff dane, aby od nich czyns wiecznemi czasy brali, a za grzechy moje P. Boga błagali” ${ }^{50}$. W dniu 12 grudnia 1643 roku kanonik krakowski i sandomierski a także kustosz koronny ks. Piotr Konstanty Złotnicki h. Nowina, który pragnął być pochowany w kościele klasztornym kamedułów na Bielanach, zapisał eremitom sporą część pozostałego po nim spadku, w tym także i bibliotekę. Prosił za to o modlitwę za swoją duszę ${ }^{51}$. Innym razem rajca krakowski i kupiec Rafał Delpace $(† 1654)$ zapisał dnia 12 kwietnia 1652 roku swemu bratu eremicie z klasztoru kamedulskiego Ambrożemu 2188 złotych ${ }^{52}$. Biskup diecezjalny krakowski Jakub Zadzik (1582-1642) w 1640 roku ustąpił za-

${ }^{49}$ [S. Andrychowicz], Series reverendorum patrum et fratrum eremitarum Camedulensium congregationis Montis Coronae tam eremi Montis Argentini supra Cracoviam in Polonia quam eremi Montis Pacis supra Coronam in Lithuania Professorum vivorum et vita defunctorum conscripta, Viennae Austriae [ok. 1760], ex typ. Gheleniana; R. Witkowski, Uwag kilka o eremach kamedulskich..., dz. cyt., s. 165; W. Murawiec OFM, Andrychiewicz (Andrychowicz) Serafin Sebastian († 1773), kameduła, historyk swego zakonu, [w:] Słownik polskich teologów katolickich, T. 1, red. H. E. Wyczawski OFM, Warszawa 1981, s. 50-51.

${ }^{50}$ Dług śmiertelności wypłacić potrzeba. Wybór testamentów mieszczan krakowskich z XVIIXVIII wieku, oprac. E. Danowska, [w:] Rozprawy Wydziału Historyczno-Filozoficznego [PAU], T. 112, Kraków 2011, s. 13.

${ }^{51}$ BCzart. rkps 2894 V, s. 269-284; L. Łętowski, Katalog biskupów, prałatów i kanoników krakowskich, t. 4: Prałaci i kanonicy krakowscy, Kraków 1853, s. 316; J. Wiśniewski, Katalog prałatów i kanoników sandomierskich od 1186-1926 tudzież sesje kapituły sandomierskiej od 1581 do 1866 r., Radom 1926, s. 329.

52 BCzart., rkps 2894 V, s. 248-249. 
konnikom dziesięcinę snopową ze wsi Ryczów, podobnie postąpił później biskup Jan Michałowski (1623-1699) ${ }^{53}$. Znamienne było uzasadnienie zapisu testamentowego aptekarza i rajcy krakowskiego Jana Pernusa (1615-1678), który, przekazując w roku 1677 do klasztoru bielańskiego „obrazy wszytkie”, kazał zanotować: „bom ja od tych ojców z młodości mojej i zawsze wielkiego dobrodziejstwa doznawał" ${ }^{4}$. Krąg krakowskich dobroczyńców klasztoru kamedułów na Bielanach jest znacznie szerszy, aniżeli wskazuje na to świadectwo zachowanych dokumentów, wiele bowiem dokumentów zaginęło albo też celowo nie zostało zapisanych ${ }^{55}$.

Założyciele reformatorskich pustelników z Monte Corona byli także znakomitymi humanistami. Twórcy kamedulskiej kongregacji Paweł Giustiniani, jak i Wincenty ( $w$ świecie Piotr) Quirini (ok. 1479-1514) byli przepojeni słowem Bożym zawartym w Piśmie Świętym, ale jednocześnie czerpali obficie z Seneki i Cycerona, z Orygenesa i ze św. Piotra Damianiego, a także i z Petrarki. Dlatego w każdym kamedulskim klasztorze musiała być biblioteka. Lektura była więc u kamedułów jedną z bardziej istotnych form zakonnej formacji. Swoją historię, i to ciekawą, posiada także biblioteka klasztoru na Bielanach. Swój początek wzięła zapewne ze zbiorów marszałka Wolskiego. Istotnym jej fundamentem były zbiory cennej biblioteki liczącej około tysiąca pięćset tomów, a zawierającej wartościowe i rzadkie manuskrypty, którą przekazał klasztorowi dworzanin biskupa Marcina Kromera a także przyjaciel i zaufany marszałka Wolskiego, kawaler jerozolimski, podróżnik, humanista i poliglota krakowski Paweł Maurycy Henik (ok. 1548-1623) ${ }^{56}$. W czasie swoich podróży do Włoch, Francji, Hiszpanii i na Bliski Wschód, do Palestyny i Cypru, nabywał jakieś książki, kupował także greckie rękopisy dzieł Ojców Kościoła Wschodniego ${ }^{57}$. Dwie trzecie tego księgozbioru jest w języku łacińskim, pozostałe w języku greckim, hebrajskim, hiszpańskim, francuskim, niemieckim, włoskim i nawet chalcedońskim. Pochowany został w kościele klasztornym, prawdopodobnie pod kaplicą św. Jana

${ }^{53}$ Archiwum Kurii Metropolitalnej w Krakowie, rkps AOff. T. 152, s. 30-33; BCzart., rkps 2894 V, s. 303-304.

${ }^{54}$ Dług śmiertelności wypłacić potrzeba..., dz. cyt., s. 50.

${ }_{55}$ J. Wojtowicz, Trzech Janów Baptystów - Włosi w renesansowym Krakowie, „Rocznik Biblioteki Polskiej Akademii Nauk w Krakowie”, T. 49, 2004, s. 28.

${ }^{56}$ L. Hajdukiewicz, Henik Maurycy Paweł (zm. 1623), [w:] Polski słownik biograficzny, t. 9, red. K. Lepszy, Wrocław 1960/1961, s. 390-391.

${ }^{57}$ J. Bieniarzówna, Schyłek świetności, [w:] Dzieje Krakowa, red. J. Bieniarzówna, J. M. Małecki, t. 2: Kraków w wiekach XVI-XVIII, Kraków 1984, s. 327. 
Chrzciciela ${ }^{58}$. Swój księgozbiór ofiarował w 1654 roku bielańskim kamedułom również dziekan i pleban opatowski ks. doktor Łukasz Sieradzki († 1654). Kolejnym współfundatorem klasztornej biblioteki był kanonik krakowski Jan Chryzostom Bodzenta h. Szeliga (ok. 1615-1678), który także został pochowany pod posadzką tego kościoła ${ }^{59}$. Jego biblioteka liczyła prawdopodobnie około 3 tysięcy tomów. Księgozbiór ten był przede wszystkim teologiczny, choć zawierał też dzieła świeckie i humanistyczne. Swoje księgozbiory ofiarowali eremitom kamedulskim także doktor praw Michał Frycowski († 1657), doktor medycyny z Padwy, a później kameduła, br. Paweł, czyli Władysław Mitkowski. Ostatnim znanym, który ofiarował swój cały księgozbiór temu klasztorowi, był również późniejszy kameduła (od 30 maja 1699), pochodzący z Prus Jan Henryk Panring (1662-1724), wcześniej profesor medycyny na Uniwersytecie w Królewcu, jak też autor wielu prac z zakresu lecznictwa ${ }^{60}$. Utworzona w ten sposób biblioteka bielańska należała do cenniejszych polskich księgozbiorów. W interesującym nas okresie liczyła przynajmniej 250 rękopisów bibliotecznych, 78 inkunabułów i 6405 druków z XVI-XVIII wieku ${ }^{61}$. W takim rodzaju życia, cechującym się surowym milczeniem, który przyjmowali kameduli, biblioteka w klasztorze była niezmiernie ważna. Według Jean’a Leclercq’a (1911-1993) była to przede wszystkim „literatura milczenia”62.

${ }^{58}$ S. Tomkowicz, Bielany, [w:] Biblioteka Krakowska, t. 26, Kraków 1904, s. 32.

${ }^{59}$ Tamże.

${ }^{60}$ C. F. Walther, C. Pieters, Catalogue méthodique des dissertations ou thèses académiques imprimées par les Elzevir de 1616 à 1712. Recueillies pour la première fois dans la Bibliothèque Impériale à St. Pétersbourg et décrites par [...], Bruxelles 1864, s. 54; J. Serczyk, Albertyna. Uniwersytet w Królewcu (1544-1945), [w:] Biblioteka Olsztyńska, t. 27, Olsztyn 1994, s. 50; był on autorem lub współautorem następujących pozycji: J. H. Panring, Dissertatio medico-chirurgica inauguralis De gangraena \& sphacelo, Lugduni Batavorum 1690, apud Abrahamum Elzevier; J. H. Panring, Dissertatio medica De conservanda sanitate illustrium virorum, quam [...] publicae eruditorum disquisitioni submittit Johannes Henricus Parning [...] respondente Daniele Szentkereszti [....], Regiomonti 1693, typis Reusnerianis; P. J. Hartmann, J. S. Lange, J. H. Panring, M. Kunter, Exercitationum anatomicarum in publicas lectiones de iis quae contra peritiam veterum anatomicam afferuntur in genere prima, Regiomonti 1693, typis Friderici Reusneri.

${ }^{61}$ R. Nir, Inkunabuły w Bibliotece OO. Kamedułów na Bielanach pod Krakowem, „Częstochowskie Studia Teologiczne”, [T.] 11: 1983, s. 314-316; D. Kamolowa, K. Muszyńska, Zbiory rękopisów w bibliotekach i muzeach $w$ Polsce, Warszawa 1988, s. 147.

${ }^{62}$ A. Gerhards, Dictionnaire historique des ordres religieux, [Paris 1998], s. 366-370; J. Leclercq OSB, Miłość nauki a pragnienie Boga, przeł. M. Borkowska OSB, [w:] Źródła monastyczne, t. 14, Tyniec 1997, s. 179; Tenże, Chrystus w oczach średniowiecznych mnichów, tłum. M. Borkowska OSB, [w:] Źródła monastyczne, t. 25. Kraków 2001, s. 31; A. Krawczyk, Rola książki w klasztorze, [w:] Z książka przez życie, red. A. Krawczyk, Lublin 2008, s. 169-178. 
Klasztorowi na Bielanach okazywali swoją przychylność i życzliwość królowie polscy: Władysław IV, Jan Kazimierz, Michał Korybut Wiśniowiecki i Jan III Sobieski, a nawet obaj Sasi ${ }^{63}$. Dwaj wymienieni Wazowie przyczynili się w znacznym stopniu do przyozdobienia kaplicy św. Benedykta ${ }^{64}$. Wskazuje to, iż pewne wpływy na dworskie koła, nie osobiste zapewne, posiadali krakowscy kameduli ${ }^{65}$. Król Jan Kazimierz w roku 1655 ze wzgórza bielańskiego kamedułów oglądał „przykry widok”. Widział bowiem wówczas „blask płonącego miasta”, czyli będące w płomieniach przedmieścia Krakowa: „Kleparz, Stradom, Piasek, Biskupie, Garbary i całe tak zwane Ogrody, położone na północy; płonęły w nich kościoły, klasztory, ogrody i zabudowania”, które to hetman Stefan Czarniecki nakazał spalić, aby ułatwić obronę miasta przed nadciągającym wrogiem, uniemożliwiając mu skryte podejście do obwarowań miasta. Tam właśnie dopadły króla Jana Kazimierza myśli, że „oto w jednej chwili spopiela się jego królewski los i nabyta bohaterskimi czynami chwała"66. Wówczas to kameduli pośpieszyli z pomocą materialną dla ojczyzny. „OO. Camaldulentes krakowscy zł. 848 gr. 22 i pieniędzy 9 na potrzebę Rzplitej wydali”, a w roku 1702 na wojnę z Karolem XII wysłali dwóch pocztowych $^{67}$. W czasie potopu Szwedzi w wyniku denuncjacji jednego z zakonników wypędzili z klasztoru kilku pozostałych mnichów, a całe wyposażenie, jak też zgromadzone plony zrabowali ${ }^{68}$.

Przebywali w tymże eremie krócej czy dłużej różni dostojnicy kościelni czy świeccy. Bardzo często bowiem zamieszkiwali w klasztorze pod koniec życia przygotowując się na śmierć, poświęcając ostatnie swe lata na modlitwę i „dewocję” w klasztornej ciszy. W tym kontekście pojawiają się nazwiska takich duchownych, jak: ks. Jan Kurdwanowski h. Półkozic (†1730), kanonik krakowski, ks. Mikołaj Ludwik Grabiański (†1714), sekretarz królewski, ks. Franciszek Sutorski (†1718) kanonik wawelskiej kolegiaty św. Michała. Spośród świeckich dostojników przebywających w tym klasztorze wymienić należy: Andrzeja Żydowskiego h. Doliwa (ok. 1640-1721), długoletniego sędziego grodzkiego i chorążego krakowskiego ${ }^{69}$,

${ }^{63}$ L. Zarewicz, Zakon kamedułów..., dz. cyt., s. 57-67.

${ }^{64}$ S. Tomkowicz, Bielany..., dz. cyt., s. 15.

${ }^{65}$ K. Górski, Zarys dziejów duchowości w Polsce, Kraków 1986, s. 187-188.

${ }^{66}$ W. Kochowski, Lata potopu 1655-1657, tłum. L. Kukulski, Warszawa 1966, s. 40; L. Podhorodecki, Hetman Stefan Czarniecki, Warszawa 2009, s. 110.

${ }^{67}$ A. Grabowski, Przedmieścia i okolice Krakowa..., dz. cyt., s. 98.

${ }^{68}$ L. Zarewicz, O. Bernard Szymoński (Typ polskiego ascety), „Kalendarz Katolicki Krakowski”, R. 9, 1889, s. 86 .

${ }^{69}$ G. A. Wiśniowski, Bracia Mniejsi w Kętach. Geneza i znaczenie klasztoru, „Almanach Kęcki” [T.] 3, 1999, s. 7. 
Jana Pawła Fryznekiera († 1722), zasłużonego sekretarza królewskiego i znawcę prawa polskiego, Józefa Władysława Witkowskiego h. Odrowąż († 1737), Remigiana Skarbka Kiełczewskiego h. Habdank, stolnika urzędowskiego (przebywał tu w latach 1737-1748), Macieja Załuskowskiego h. Rola z Kaliszkowic (†1757), skarbnika sieradzkiego, Bogusława Bielskiego h. Jelita ( $\uparrow 1759)$, chorążego lwowskiego $^{70}$. Inni duchowni zaś często odprawiali w klasztorze tym swoje doroczne rekolekcje, dni skupienia czy też korzystali z sakramentu spowiedzi. Biskup diecezjalny krakowski Piotr Gembicki (1642-1657) schronił się tymże klasztorze w październiku 1653 roku przed grasującą w mieście zarazą ${ }^{71}$. Swoje skupienia w tym klasztorze miały także grupy świeckich. Jedną z nich było Confraternitas Litteratorum - Bractwo Literackie przy kościele Św. Wojciecha na Rynku. „Przez drogę Officium B. V. Mariae śpiewając, i tam Mszy św. słuchać, także ojca swego athortacyi, którą zwykł miewać przed eremitorium u krzyża. A ztamtąd nazad wracają się z przystojnem nabożeństwem i uczciwością"72.

W podziemiach kościoła kamedulskiego pw. Wniebowzięcia Najświętszej Maryi Panny oprócz już wspomnianych fundatora Wolskiego, gorliwego opiekuna klasztoru Henika oraz dobrodziejów ks. Bodzenty i ks. Sieradzkiego zostali pochowani: wywodzący się z Krakowa biskup kamieniecki Stanisław Wojeński († 1685), kanonik kolegiaty św. Michała na Wawelu ks. Jan Sucharski (†1715), rajca krakowski i burmistrz, lekarz Jan Kanty Łukaszkiewicz ( $† 1708)$, nieznany z imienia Węgrzynowic, syn rajcy krakowskiego, Jan Zabielski (†1718) ze swoją żoną Anną z Oraczewskich $(† 1700)$ i córką Teresą Śmietanką, Józef Witkowski († 1737), konfrater kamedulski, który spędził w klasztorze swoje ostatnie 20 lat, Krystian Teofil Szmidt $(\dagger 1737)$, lekarz i dworzanin kardynała Jana Lipskiego, Mikołaj Ludwik Grabiański ( $† 1714)$, prefekt lipowiecki i dobroczyńca klasztoru, oraz jego żona Maria Ludwika († 1711), Maciej Załuskowski (†1757) i Bogusław Bielski, chorąży lwowski, konfrater kamedulski, który zmarł w klasztorze $(† 1759)^{73}$.

Pomimo iż zakonnicy ci nie zajmują się duszpasterstwem czy inną działalnością zewnętrzną, to ich oddziaływanie dokonuje się poprzez świadczenie o „wartościach, bez których świat nie może się obejść, [gdyż] nadają one życiu sens”. Papież Jan Paweł II (1920-2005) składając w niedzielę 5 września 1982 roku wizytę w klasztorze kamedulskim w Fonte Avellana wspominał, „jak głęboko zbudowani byli [w Krakowie] wierni odwiedzający ich pustelnie, z których promieniowało

\footnotetext{
${ }^{70}$ L. Zarewicz, Zakon kamedułów..., dz. cyt., s. 68.

${ }^{71}$ Tamże, s. 30-31.

${ }^{72}$ A. Grabowski, Przedmieścia i okolice Krakowa..., dz. cyt., s. 98.

${ }^{73}$ L. Zarewicz, Zakon kamedułów..., dz. cyt., s. 27.
} 
tajemnicze odczucie pokoju, radości i świętości"74. Zatem pomimo swego odejścia od świata mnisi kamedulscy nie odwracali się od człowieka i jego problemów, zwłaszcza duchowych ${ }^{75}$. Podobne przekonanie posiadał siedemnastowieczny uniwersytecki pedel Piotr Jacek Pruszcz (1605- po 1667?), który w Klejnotach Stołecznego Miasta Krakowa zanotował, że kameduli „pielgrzymy przyimuią i inszych potrzebnych $z$ wielkim poszanowaniem podeymuią”, a klasztor „kwitnie w wielkiey obserwancyi zakonney"76. Kameduli bowiem pamiętali zawsze to, co zapisane jest w ich zakonnych konstytucjach, że „milczenie jest rzeczą bardzo świętą, byleby nie przechodziło granic roztropności, która poucza o czasie milczenia i mówienia"77, gdyż tertium bonum św. Romualda - evangelium paganorum jest szczytem powołania monastycznego kamedulskiego mnicha ${ }^{78}$.

Konstytucje zakonne kamedułów stanowiły, iż niewiastom nie wolno było (i nie jest) wchodzić do ich kościoła oprócz trzech dni w roku' ${ }^{79}$. Odnotował to „poeta sarmackiej prowincji” Stanisław Samuel Szemiot h. Łabędź (ok. 1657-1684), że białogłowom wchodzić do kościoła można tylko „25 martii, 19 junii, 15 augustii” ${ }^{80}$, a także Pruszcz, który zaznaczył: „płci białogłowskiey do kościoła nie puszczaią, tylko trzy razy w rok"81, pomimo iż brewe papieża Pawła V Splendor paterne gloriae z 19 lutego 1610 roku umożliwiało otwarcie klasztoru w 12 dni $\mathrm{w}$ ciągu roku ${ }^{82}$. Nic więc dziwnego, że w te dni u kamedułów bywał tłok zwiedzających wiedzionych opinią wyjątkowej, wręcz egzotycznej surowości życia mnichów, mających spać w trumnach i pozdrawiać się słowami „memento mori”. Krakowianie obojga płci i wszelkiego stanu szczególnie gromadnie pojawiali się

${ }^{74}$ Jan Paweł II, Wartości, bez których świat nie może się obejść [Homilia w klasztorze kamedułów w Fonte Avellana, 5 IX 1982], „L'Osservatore Romano”, wyd. polskie, R. 3, 1982, nr 9, s. 18.

75 K. Klimas, Prolog do zrozumienia klasztoru oo. Kamedułów na Bielanach w Krakowie, „Przestrzeń i Forma” R. [3], 2007, nr 7/8, s. 229.

76 P. H. Pruszcz, Kleynoty Stołecznego Miasta Krakowa..., dz. cyt., s. 180.

77 Reguła św. Benedykta i Konstytucje..., dz. cyt., s. 46; legendą jest twierdzenie, że przy spotkaniu pozdrawiają się słowami „memento mori”, podobnie jak to, że śpią w trumnach - legenda ta jednak w uporczywy sposób trwa - B. Krakowiak, Dziedzictwo kulturowe zakonu kamedułów na ziemiach polskich, „Turyzm”, t. 16, 2006, z. 2, s. 87.

${ }^{78}$ L. Saraceno OSBCam, „Evangelium paganorum” jako świadectwo dane przez Pięciu Braci Męczenników w centrum modelu hagiograficznego św. Romualda, [w:] Męczennicy z Międzyrzecza 1003-2003..., dz. cyt., 136-137.

79 Reguła św. Benedykta i Konstytucje..., dz. cyt., s. 16, nr 10.

${ }^{80}$ S. S. Szemiot, Dariusz peregrynacyi na różne miejsca święte szczęśliwie odprawionej anno 1680, [w:] Silva Medii et Recentioris Aevi, t. 6, Ze starych rękopisów, Warszawa 1979, s. 109.

81 P. H. Pruszcz, Kleynoty Stołecznego Miasta Krakowa..., dz. cyt., s. 181.

82 Sommario cronologico dei documenti pontifici..., nr 105, s. 52-53. 
w omawianym okresie na Srebrnej Górze w rocznicę śmierci św. Romualda, założyciela nie tyle zakonu, co raczej eremickiej tradycji kamedulskiej, obchodzoną przez zakonników w dniu 19 czerwca. Z tej to czerwcowej uroczystości w wieku XIX wyłonił się zwyczaj pielgrzymek na Bielany na Zielone Święta, które z czasem stały się również popularnym majowym piknikiem krakowian ${ }^{83}$.

Oddziaływanie eremitów kamedulskich na mieszkańców Krakowa, i nie tylko, pomimo iż było w tym mieście największe w Polsce skupisko „wielebnych i przewielebnych”, przynosiło dobre owoce i wpisywało się złotymi zgłoskami w dzieje miasta, gdy trwając w duchowej łączności z Kościołem, zachowując optymizm wiary, dążyli do autentycznej realizacji swojej reguły, zakonnych konstytucji i ewangelicznej prostoty w duchu św. Romualda. Kameduli przyszli do Krakowa po trudnej epoce wielkich niepokojów serc w okresie reformacji, niepokojów, które dotknęły wszystkich dziedzin ludzkiego życia, przede wszystkim religijnej, ale także społecznej, umysłowej, obyczajowej; przyszli po zaprowadzeniu ładu i porządku w Kościele poprzez postanowienia Tridentinum. Przyszli, aby poprzez przykład własnego umartwienia i milczenia wlać w rozgorączkowane sarmackie głowy spokój myślenia i postępowania - tak jak spokój bieli i harmonii ich monumentalnego klasztoru górującego nad miastem. Ich zakonna prostota i ubóstwo połączyła się tutaj z barokową „tendencją wzmagającego się nadmiaru”, a wszystko po to, aby umocnić wiarę i pobożność katolików, a zawstydzić protestanckie obrazoburcze ubóstwo ${ }^{84}$. Kamedulski klasztor na Bielanach ze swoją specyficzną atmosferą był i jest miejscem wyjątkowym w kulturze i historii Krakowa, które przez swą aurę nierzeczywistości budzi w przybywających przechodniach zatrzymanie zwykłego pędu życia ${ }^{85}$. Nic więc dziwnego,

${ }^{83}$ L. Zarewicz, Zielone Świątki i majówki na krakowskich Bielanach, [Kraków 1876], s. 5, nadb.: Józefa Czecha Kalendarz Krakowski na rok 1877; O. Kolberg, Lud. Jego zwyczaje, sposób życia, mowa, podania, przysłowia, obrzędy, gusła, zabawy, pieśni, muzyka i tańce, S. 5: Krakowskie, cz. 1, Kraków 1871, s. 293; M. Dobrucka, Ze wspomnień śląskiego górnika Franciszka Musialika, „Kwartalnik Opolski”, t. 23, 1977, nr 3, s. 85-86; S. Pagaczewski, Z tobołkiem za Kraków, Kraków 1979, s. 43-58; A. Gerhards, Dictionnaire historique des ordres religieux..., dz. cyt., s. 121.

${ }^{84}$ M. Fabiański, Złoty Kraków, Kraków 2010, s. 136; K. Klimas, Prolog do zrozumienia klasztoru oo. Kamedułów na Bielanach w Krakowie..., dz. cyt., s. 231.

${ }^{85}$ T. Chrzanowski, Sarmacka eschatologia, „Twórczość”, R. 35, 1979, nr 8, s. 68. 
że papież Jan Paweł II w przywoływanej na wstępie homilii w Fonte Avellana mówił, że od czasu swego przyjścia do Polski kameduli „są [...] naprawdę mądrymi przewodnikami i przykładem dla wielu wiernych mojej Ojczyzny" ${ }^{\prime 6}$.

\section{Riassunto}

Bielany - la località preferita degli abitanti di Cracovia.

I rapporti dei monaci camaldolesi di Bielany con Cracovia nellepoca della Polonia antica

I monaci camaldolesi, fatti venire a Cracovia all'inizo del Settecento dal monastero italiano di Monte Corona dall'iniziativa del maresciallo Mikołaj Wolski, si sono inseriti perfettamente nella vita e nel paesaggio della città. Pur essendo eremiti, i loro rapporti con questa città erano vivi e molteplici. Gli abitanti della città s'interessavano molto del loro sviluppo e, questa fu la causa, che molti cittadini li aiutavano con le loro donazioni. Si possono notare anche fra i monaci molti figli delle famiglie borghesi di Cracovia. Non meraviglia perciò che al monastero localizzato in un posto molto pittoresco venivano gli abitanti della città, innanzitutto in giorni quando ci si poteva entrare. I monaci e la loro attività si sono iscritti notevolmente nella riforma posttridentina della Chiesa in Polonia. Il monastero di Bielany con la sua particolare atmosfera è un luogo eccezionale nella cultura e storia di Cracovia che finora sveglia nei pellegrini e visitanti il fascino della tranquillità della vita soprannaturale.

Traduzione: Krzysztof Tyburowski

${ }^{86}$ Jan Paweł II, Wartości, bez których świat nie może się obejść..., dz. cyt., s. 18. 
Bielany - ulubione miejsce Krakowa...

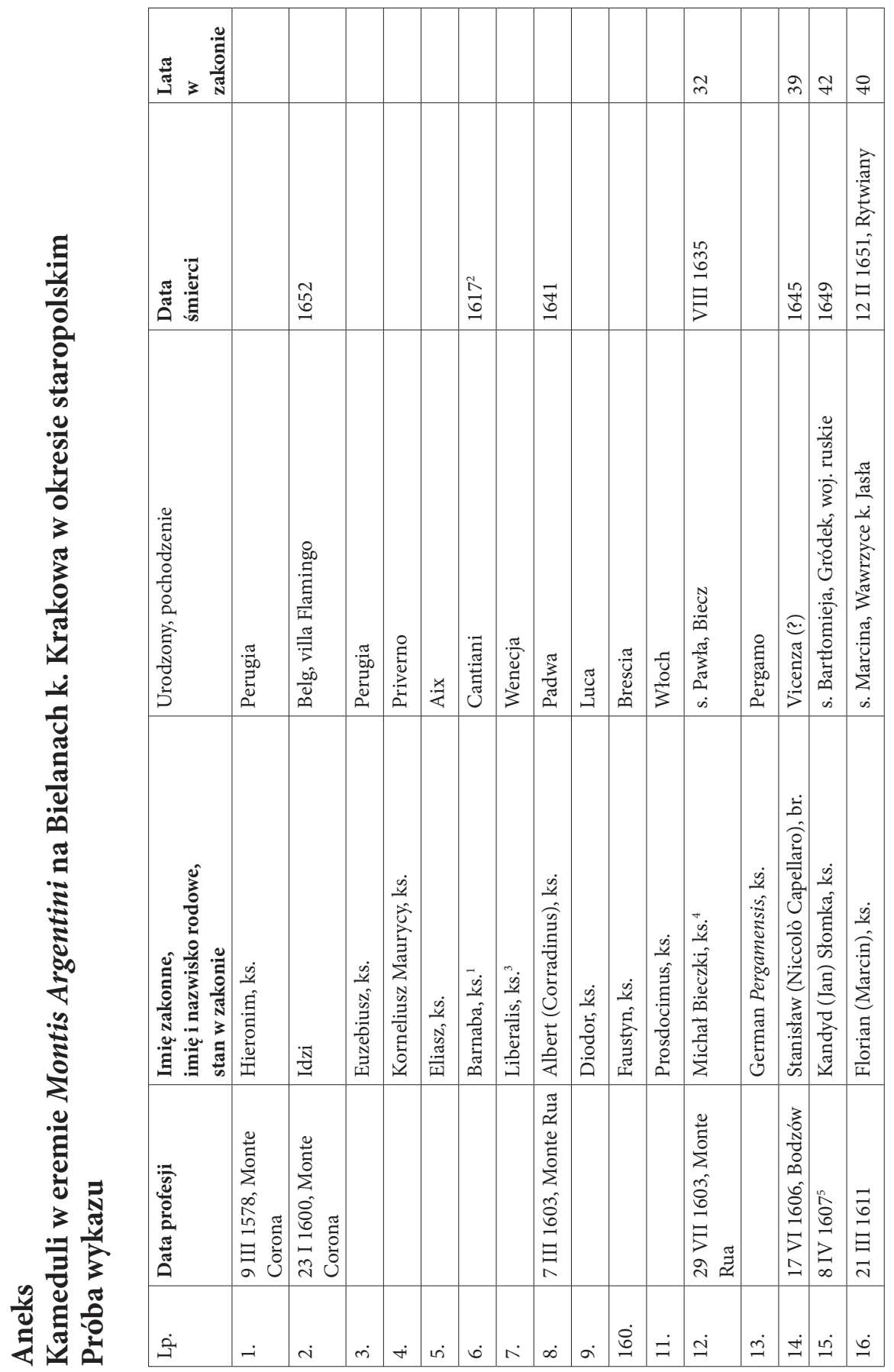




\begin{tabular}{|c|c|c|c|c|c|c|c|c|c|c|c|c|c|c|c|c|c|c|c|c|}
\hline 6 & 으 & ठే & $\infty$ & 6 & $\wedge$ & $\hat{n}$ & $R$ & $\hat{6}$ & 3 & $\widetilde{\sigma}$ & F & in & & & in & $\stackrel{m}{m}$ & $\tilde{6}$ & 6 & పే & L \\
\hline 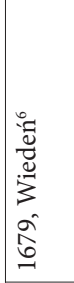 & స్ర్ర & 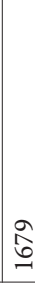 & $\stackrel{2}{2}$ & $\begin{array}{l}\infty \\
\stackrel{0}{0}\end{array}$ & 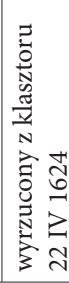 & 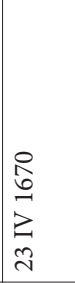 & 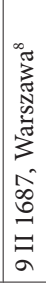 & $\underset{-}{\stackrel{+}{0}}$ & 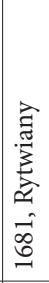 & $\mid$\begin{tabular}{l} 
\\
\\
\\
8 \\
$\infty$ \\
0 \\
\hdashline
\end{tabular} & 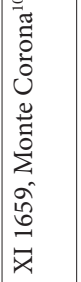 & $\underset{-}{\stackrel{+}{6}}$ & & & $\begin{array}{l}0 \\
6 \\
0\end{array}$ & 惷 & $\begin{array}{l}0 \\
\infty \\
0 \\
0\end{array}$ & 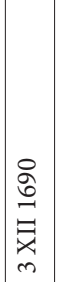 & $\begin{array}{l}\infty \\
\substack{\infty \\
0}\end{array}$ & 同 \\
\hline 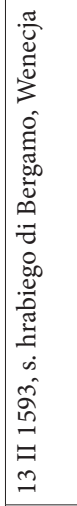 & 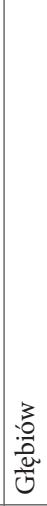 & 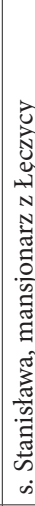 & 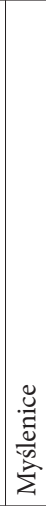 & 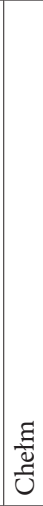 & 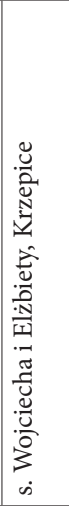 & 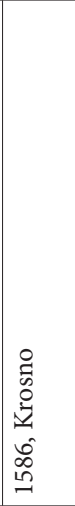 & 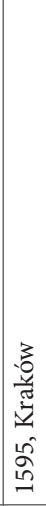 & 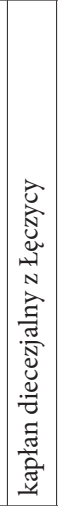 & 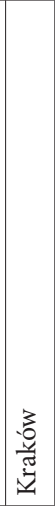 & 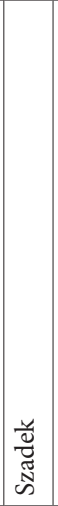 & 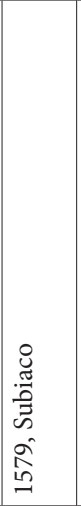 & 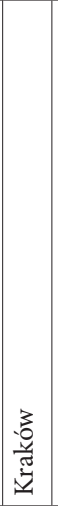 & $\frac{\pi}{3}$ & \begin{tabular}{|c|} 
\\
.$\frac{\pi}{\tilde{2}}$ \\
$\frac{\tilde{0}}{3}$ \\
3
\end{tabular} & 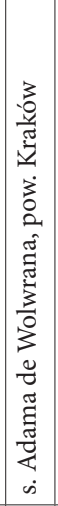 & 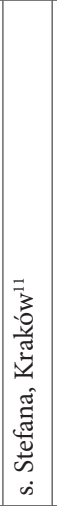 & 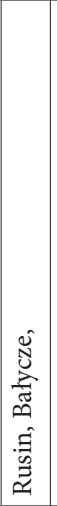 & 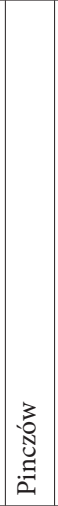 & 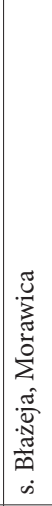 & 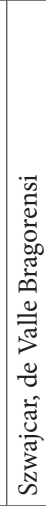 \\
\hline 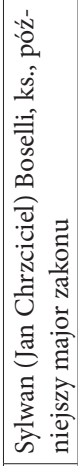 & 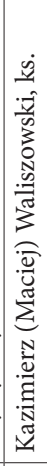 & 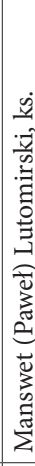 & 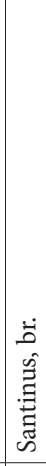 & 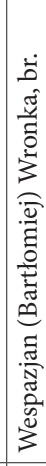 & 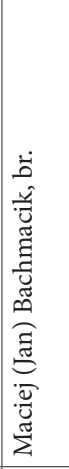 & 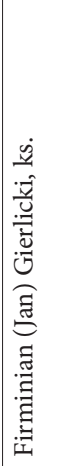 & 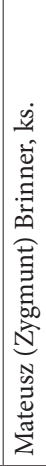 & 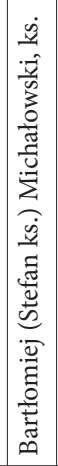 & 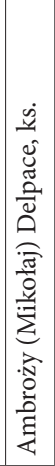 & 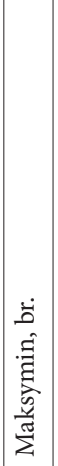 & 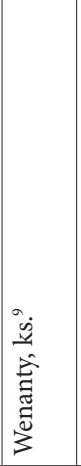 & 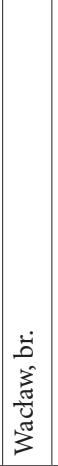 & 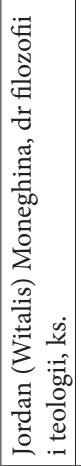 & 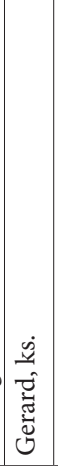 & 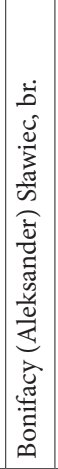 & 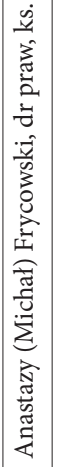 & 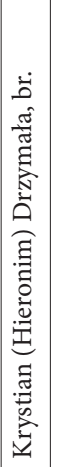 & 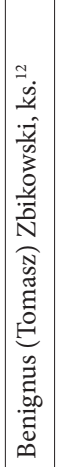 & 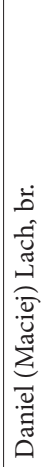 & 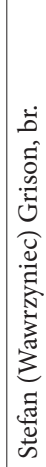 \\
\hline 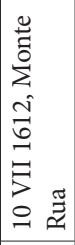 & 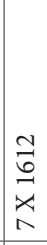 & $\begin{array}{l}\frac{10}{6} \\
\\
\overline{2} \\
=\end{array}$ & $\begin{array}{l}\frac{10}{6} \\
0 \\
\bar{x} \\
-1\end{array}$ & $\begin{array}{l}0 \\
0 \\
\vdots \\
\exists \\
\vdots \\
\infty \\
\infty\end{array}$ & 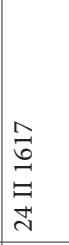 & 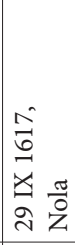 & 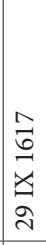 & 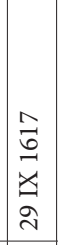 & $\begin{array}{l}\infty \\
\vec{\sigma} \\
\Xi \\
\exists \\
\underset{\sim}{J} \\
\end{array}$ & 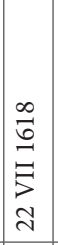 & 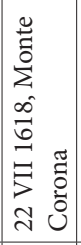 & 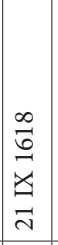 & $\begin{array}{l}a \\
\sigma \\
\vdots \\
0\end{array}$ & 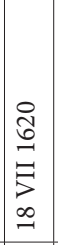 & 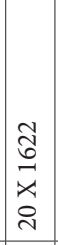 & 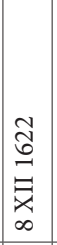 & 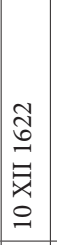 & 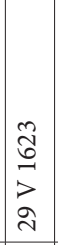 & 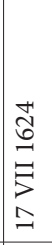 & 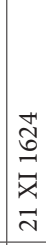 \\
\hline$\therefore$ & $\stackrel{\infty}{\rightarrow}$ & 2 & $\dot{\sim}$ & $\vec{v}$ & ก่ & $\ddot{\sim}$ & di & 로 & 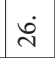 & $\widehat{\imath}$ & 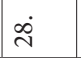 & নे & $\dot{m}$ & $\dot{m}$ & กี & $\dot{m}$ & मे & in & $\dot{m}$ & 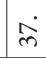 \\
\hline
\end{tabular}




\begin{tabular}{|c|c|c|c|c|c|c|c|c|c|c|c|c|c|c|c|c|c|c|c|c|c|c|}
\hline$\tilde{m}$ & m. & F & $\stackrel{F}{F}$ & $\exists$ & $\exists$ & in & f & I & fr & in & in & 8 & & 䓃 & 品 & $\cong$ & in & \& & in & $m$ & $\tilde{m}$ & $\hat{m}$ \\
\hline 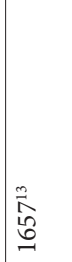 & 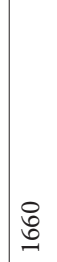 & $\begin{array}{l}\hat{0} \\
\stackrel{0}{\sigma}\end{array}$ & 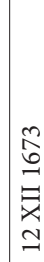 & 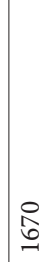 & صِ & $\begin{array}{l}\overrightarrow{0} \\
\stackrel{\sigma}{\sigma}\end{array}$ & 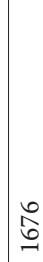 & مُ & 芯 & 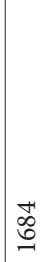 & $\overrightarrow{\overrightarrow{0}}$ & 足 & & 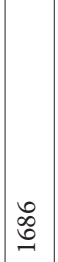 & 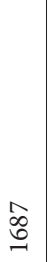 & $\mid \begin{array}{l}\stackrel{2}{2} \\
\end{array}$ & \begin{tabular}{|l} 
\\
\\
$\infty$ \\
0 \\
0 \\
0
\end{tabular} & 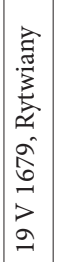 & & 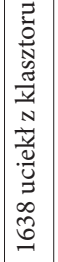 & 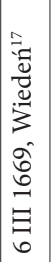 & مِ \\
\hline 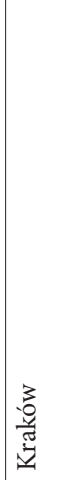 & 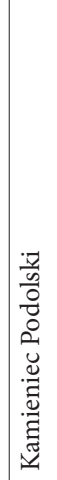 & 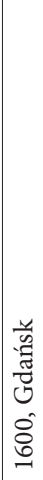 & 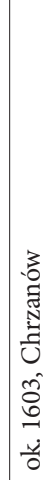 & 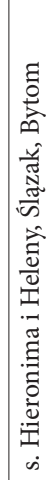 & 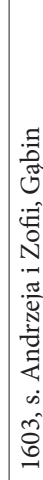 & & 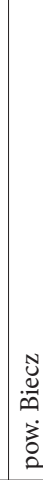 & 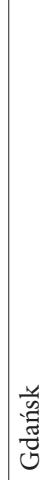 & 产 & 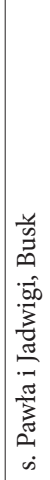 & 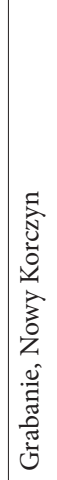 & $\begin{array}{l} \\
0 \\
0 \\
0 \\
0 \\
0 \\
0 \\
3 \\
3\end{array}$ & 䓂 & 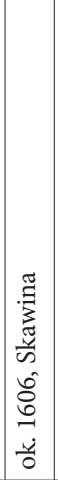 & 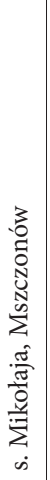 & 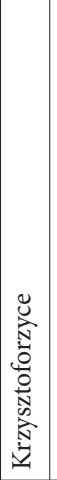 & 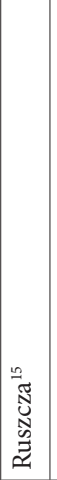 & 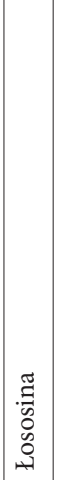 & 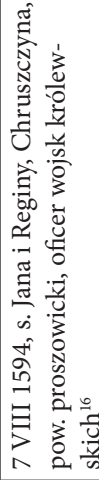 & 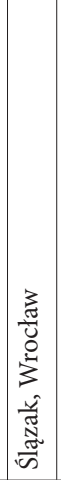 & 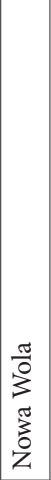 & 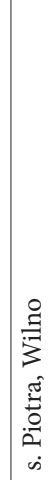 \\
\hline 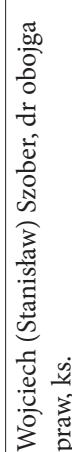 & 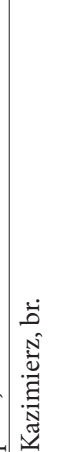 & 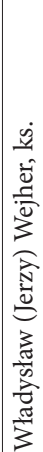 & 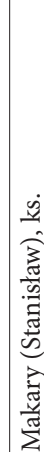 & 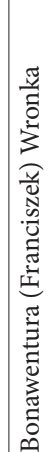 & 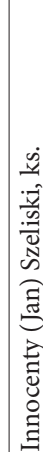 & 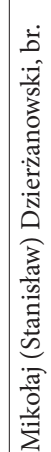 & 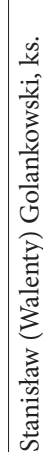 & 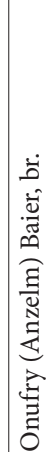 & 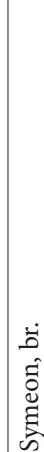 & 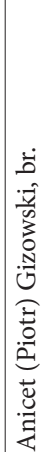 & 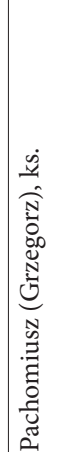 & 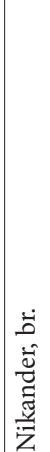 & 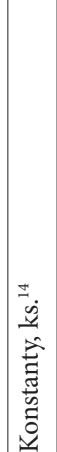 & 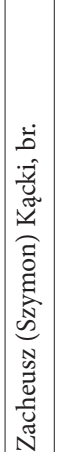 & 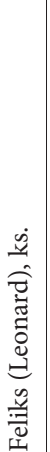 & 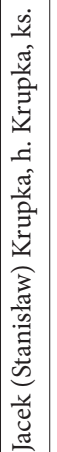 & 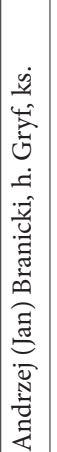 & 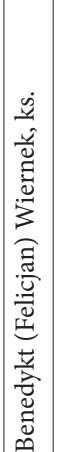 & 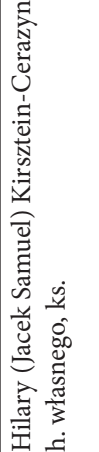 & 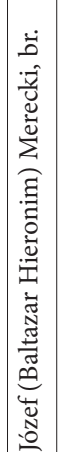 & 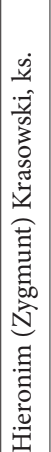 & 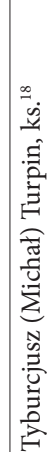 \\
\hline
\end{tabular}

\begin{tabular}{|c|c|c|c|c|c|c|c|c|c|c|c|c|c|c|c|c|c|c|}
\hline 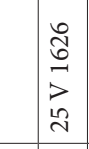 & 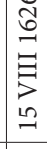 & 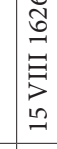 & 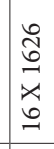 & 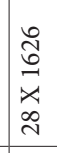 & 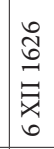 & 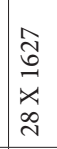 & 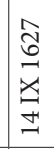 & 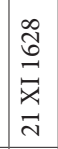 & 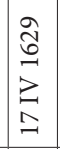 & 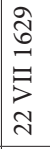 & 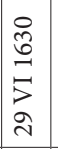 & 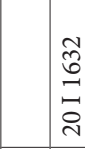 & 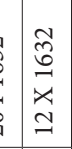 & 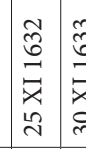 & 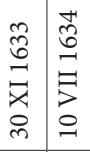 & 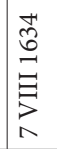 & & 㑒 \\
\hline लें & & & & $\dot{F}$ & f & ஜே & F & $\ddot{f}$ & $\underset{⿱ 亠 乂}{\stackrel{9}{q}}$ & gे & in & in & in & İ & 苫 & & $\stackrel{\infty}{i n}$ & in \\
\hline
\end{tabular}




\begin{tabular}{|c|c|c|c|c|c|c|c|c|c|c|c|c|c|c|c|c|c|c|}
\hline$\exists$ & $\stackrel{\infty}{\leftrightarrow}$ & in & $\mathscr{l}$ & $=$ & in & $\stackrel{\infty}{\rightarrow}$ & ల్ల & in & ల్ల & in & 凩 & 우 & m゙ & $\approx$ & भे & $\begin{array}{ll}\text { of } & 7\end{array}$ & 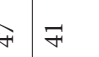 & $\stackrel{\infty}{\leftrightarrow}$ \\
\hline 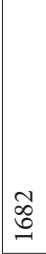 & $\mid \begin{array}{l}\mathscr{0} \\
\stackrel{0}{-1}\end{array}$ & 馬 & 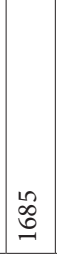 & 惫 & 跑 & 会 & 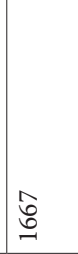 & 然 & 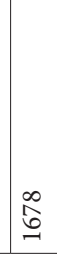 & 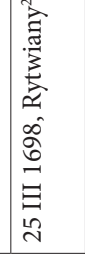 & 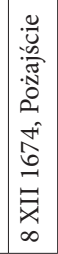 & & 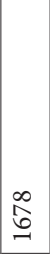 & 尽 & 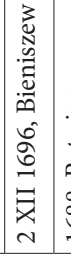 & 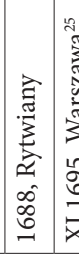 & 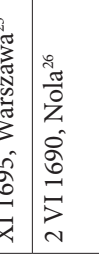 & 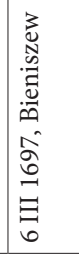 \\
\hline 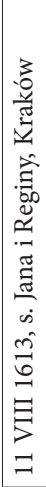 & 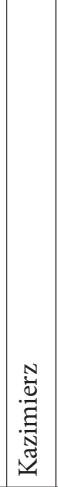 & 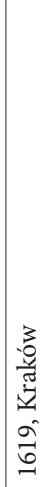 & 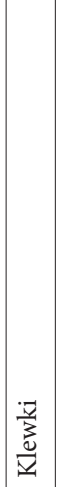 & 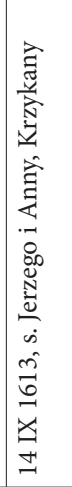 & 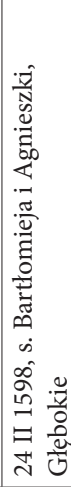 & 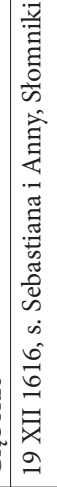 & 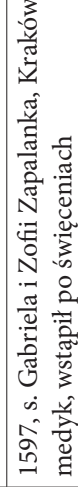 & 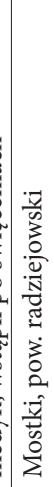 & 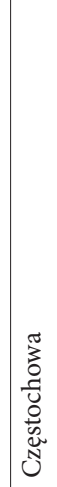 & 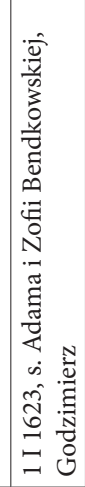 & 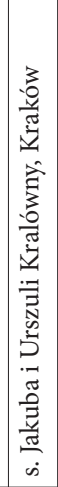 & 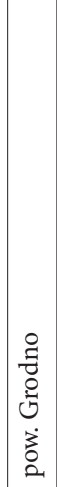 & 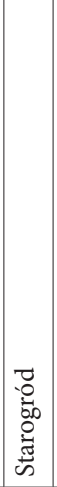 & 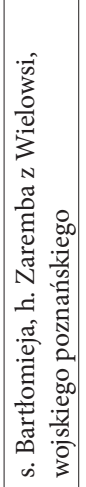 & 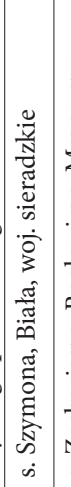 & 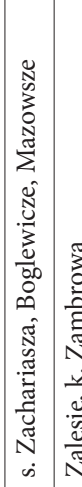 & 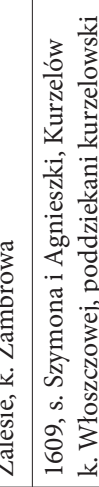 & \begin{tabular}{|}
0 \\
0 \\
0 \\
0 \\
0 \\
0
\end{tabular} \\
\hline 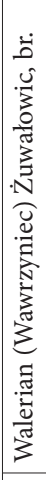 & 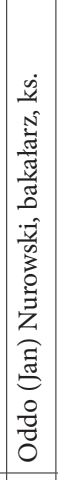 & 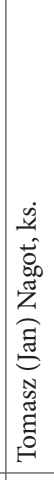 & 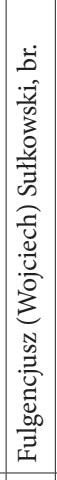 & 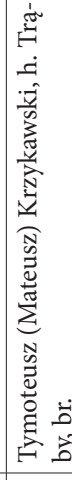 & 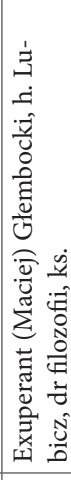 & 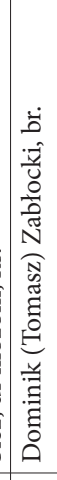 & 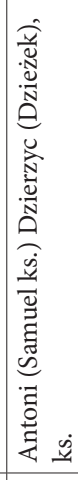 & 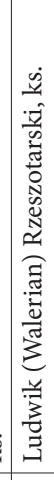 & 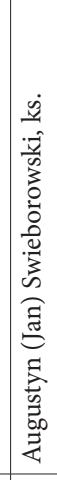 & 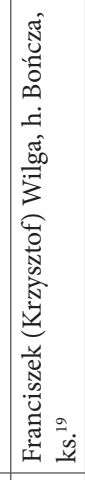 & 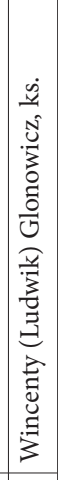 & 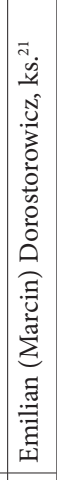 & 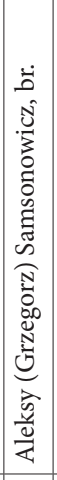 & 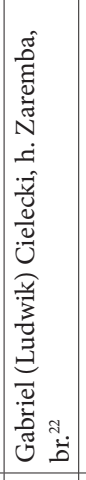 & 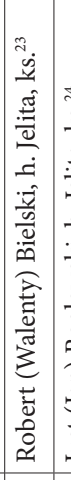 & 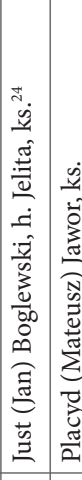 & 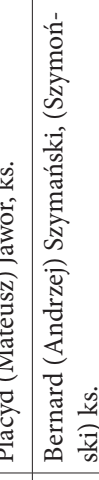 & 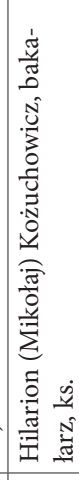 \\
\hline $\begin{array}{l}\infty \\
0 \\
0 \\
1 \\
0 \\
0 \\
-1\end{array}$ & 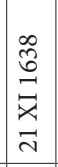 & 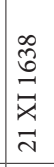 & 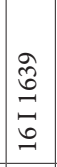 & 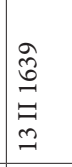 & 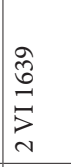 & 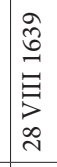 & $\begin{array}{l}\vec{F} \\
\stackrel{\vec{t}}{\not} \\
0 \\
0\end{array}$ & 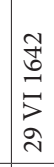 & 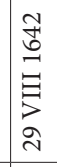 & 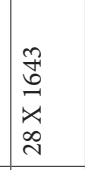 & 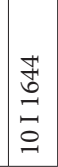 & 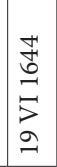 & 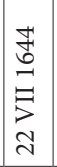 & 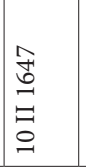 & 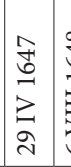 & 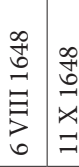 & 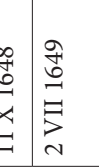 & 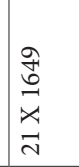 \\
\hline$\dot{b}$ & ถ่ & 8 & tే & 48 & : & 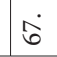 & $\infty$ & 8 & $\dot{R}$ & $\dot{\pi}$ & i & Ni & ז̇ & in & 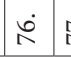 & 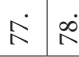 & $\infty^{\circ} \AA^{\circ}$ & $\dot{\infty}$ \\
\hline
\end{tabular}


Bielany - ulubione miejsce Krakowa...

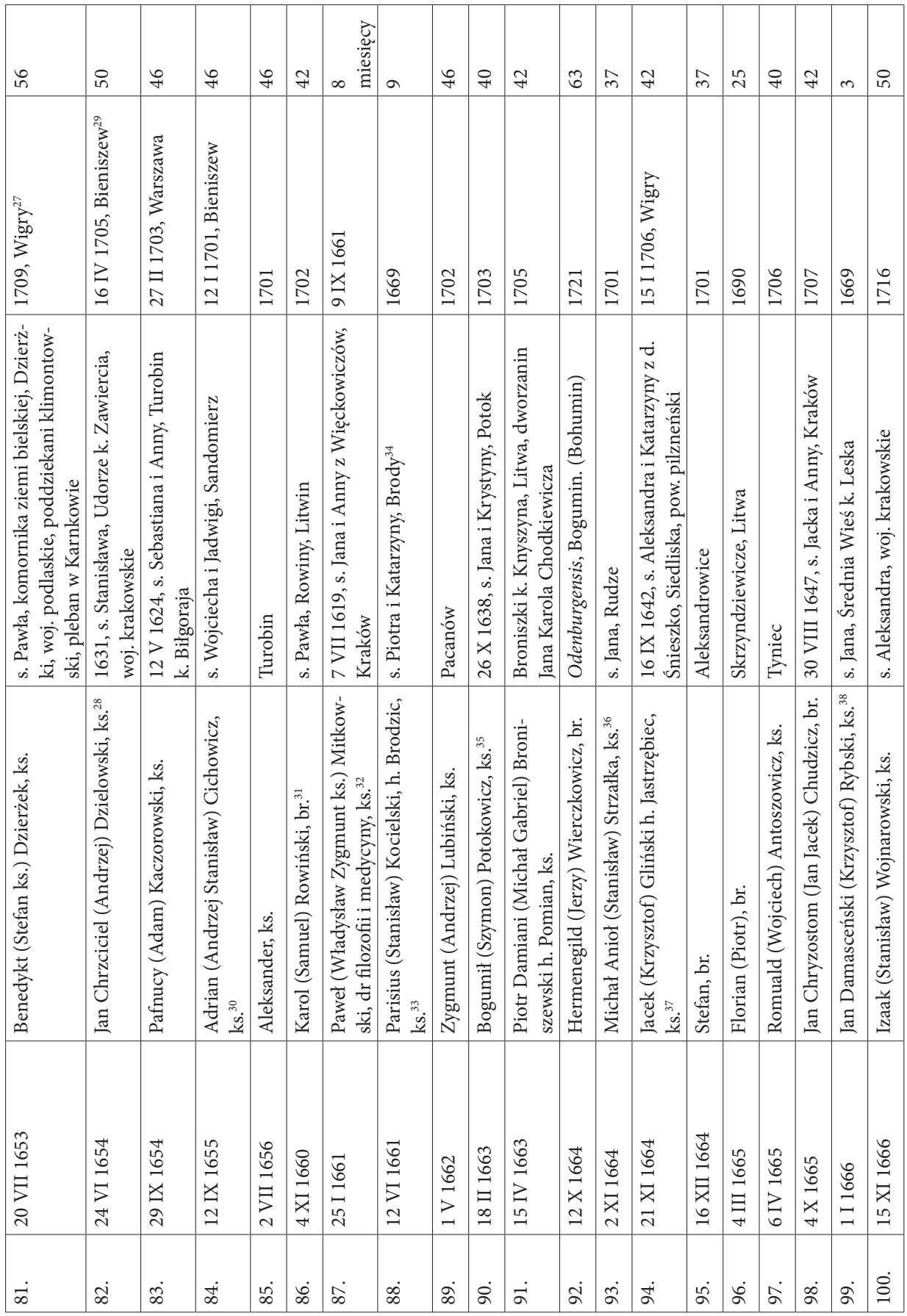




\begin{tabular}{|c|c|c|c|c|c|c|c|c|c|c|c|c|c|c|c|c|c|}
\hline 우 & $\hat{m}$ & in & $\stackrel{\infty}{m}$ & in & $\vec{m}$ & $m$ & $m$ & $\stackrel{2}{+}$ & 구 & $\hat{m}$ & & m & ㄱ & $\stackrel{n}{m}$ & m & ปे & $\tilde{m}$ \\
\hline$\stackrel{\text { }}{\beth}$ & 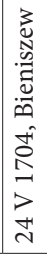 & $\stackrel{ }{\Xi}$ & 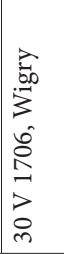 & $\stackrel{\vec{\Xi}}{\Xi}$ & 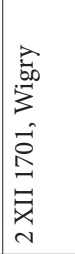 & 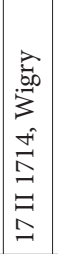 & 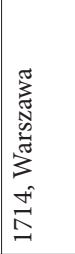 & 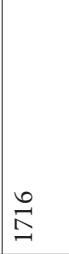 & 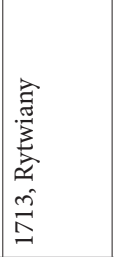 & $\stackrel{\infty}{\stackrel{2}{I}}$ & & $\stackrel{+}{\stackrel{2}{2}}$ & $\stackrel{\Delta}{I}$ & $\stackrel{ }{\stackrel{2}{1}}$ & $\stackrel{1}{\stackrel{1}{I}}$ & 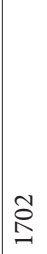 & 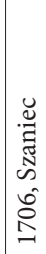 \\
\hline 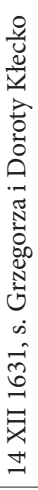 & 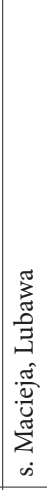 & 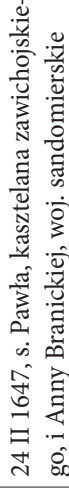 & 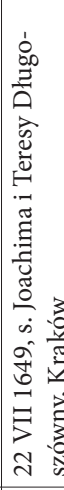 & 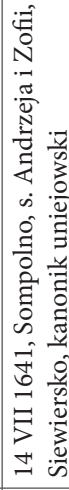 & 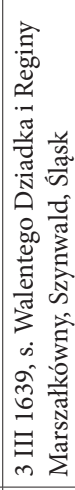 & 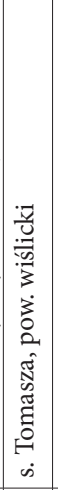 & 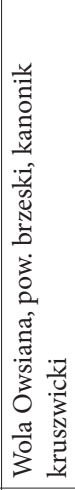 & 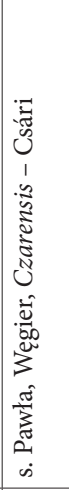 & 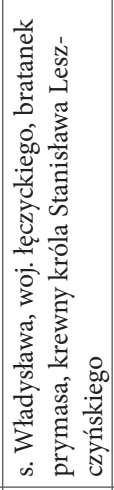 & 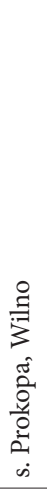 & 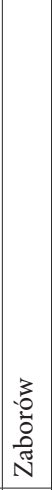 & 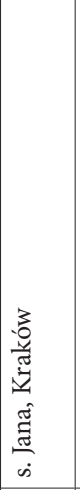 & 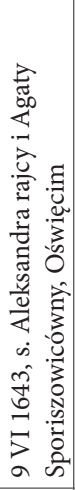 & 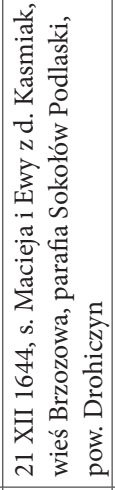 & 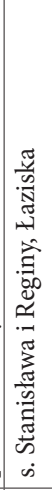 & 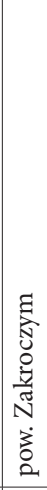 & 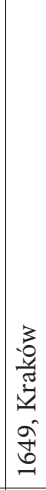 \\
\hline 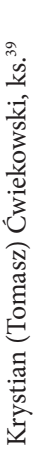 & 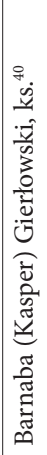 & 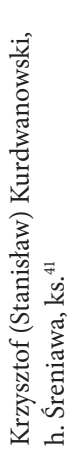 & 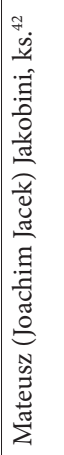 & 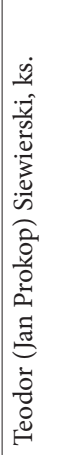 & 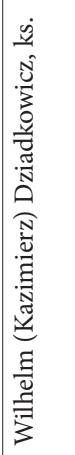 & 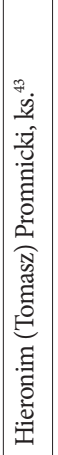 & 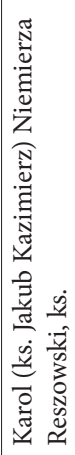 & 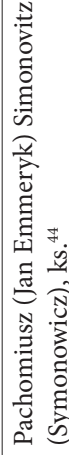 & 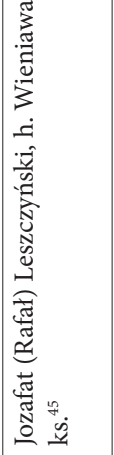 & 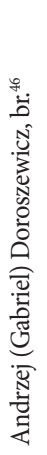 & 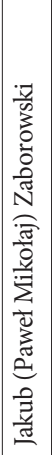 & 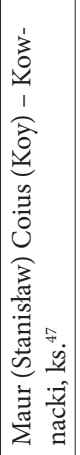 & 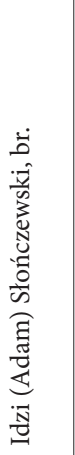 & 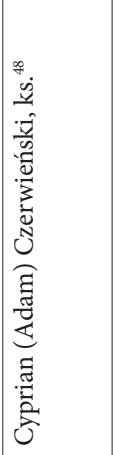 & 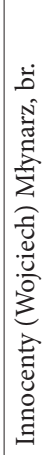 & 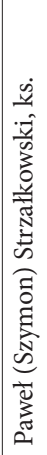 & 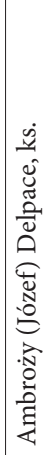 \\
\hline 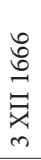 & 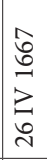 & 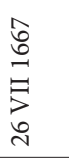 & 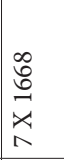 & 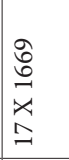 & 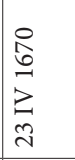 & $\begin{array}{l}-1 \\
6 \\
Z \\
z \\
\text { in }\end{array}$ & 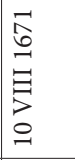 & 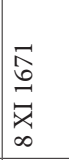 & 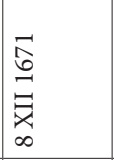 & $\begin{array}{l}\sqrt{\widehat{\sigma}} \\
\ddots \\
\text { 离 } \\
\infty\end{array}$ & $\begin{array}{l}\mathbb{N} \\
\hat{b} \\
-1 \\
\geq \\
-\end{array}$ & 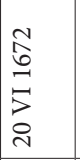 & 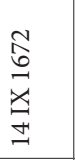 & 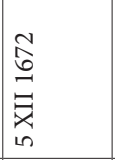 & 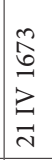 & 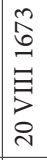 & 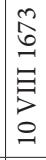 \\
\hline ¿ & ک̊ & $\stackrel{8}{0}$ & $\stackrel{+}{\circ}$ & $\stackrel{2}{\varrho}$ & $\stackrel{8}{\circ}$ & $\hat{0}$ & $\stackrel{\infty}{\stackrel{0}{0}}$ & 8 & $\stackrel{\dot{\Xi}}{=}$ & $\exists$ & $\stackrel{\beth}{\Xi}$ & $\stackrel{\ddot{g}}{=}$ & $\stackrel{+}{\Xi}$ & $\stackrel{\stackrel{20}{7}}{=}$ & $\stackrel{\dot{0}}{=}$ & $\triangleq$ & $\stackrel{\infty}{=}$ \\
\hline
\end{tabular}


Bielany - ulubione miejsce Krakowa...

\begin{tabular}{|c|c|c|c|c|c|c|c|c|c|c|c|c|c|c|c|c|c|c|c|}
\hline లి & F & $\infty$ & F & $\grave{i}$ & $m$ & $\tilde{m}$ & $\tilde{m}$ & $\stackrel{m}{m}$ & $\stackrel{m}{m}$ & $\tilde{m}$ & 7 & $\tilde{m}$ & $\underset{\sim}{\infty}$ & $\underset{m}{\infty}$ & $\tilde{m}$ & $\tilde{m}$ & ले & $F$ & ส \\
\hline 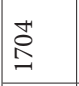 & $\stackrel{\infty}{\stackrel{\infty}{\Xi}}$ & $\underset{I}{ت}$ & $\stackrel{ }{I}$ & 용 & 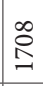 & $\stackrel{2}{\stackrel{2}{1}}$ & $\stackrel{0}{\leftrightarrows}$ & $\stackrel{m}{I}$ & $\stackrel{m}{I}$ & $\stackrel{ }{\stackrel{1}{二}}$ & $\stackrel{2}{\Xi}$ & $\vec{I}$ & 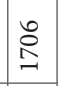 & $\stackrel{\infty}{\underset{I}{I}}$ & $\Xi$ & $\stackrel{\beth}{\Xi}$ & $\vec{\Xi}$ & $\stackrel{\widetilde{I}}{\stackrel{\Xi}{I}}$ & $\stackrel{\text { 옹 }}{\stackrel{2}{-}}$ \\
\hline 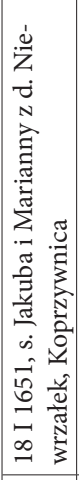 & 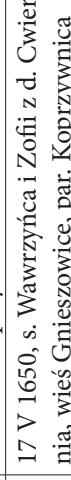 & 苟 & 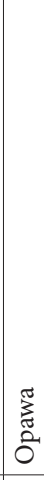 & हूँ & 厗 & 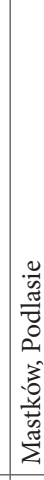 & 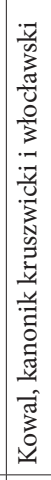 & 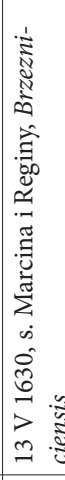 & 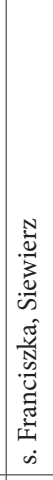 & 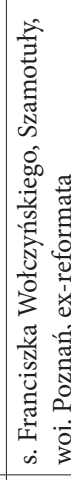 & 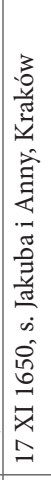 & 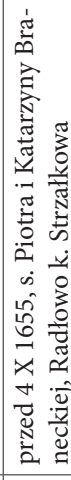 & 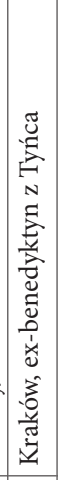 & 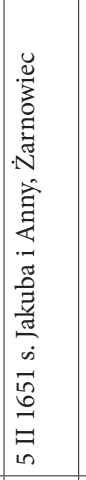 & 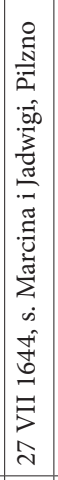 & 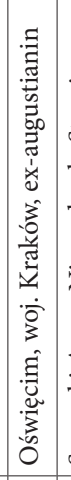 & 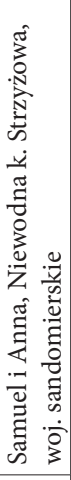 & 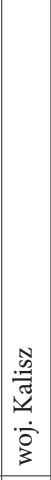 & 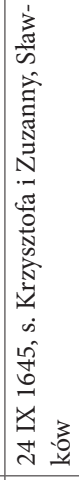 \\
\hline 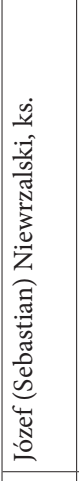 & 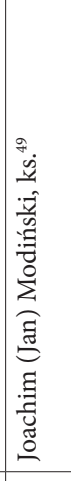 & 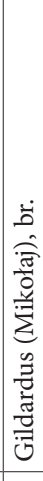 & 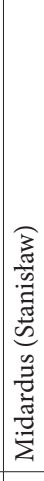 & 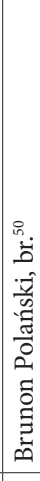 & 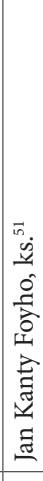 & 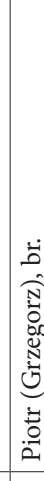 & 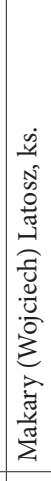 & 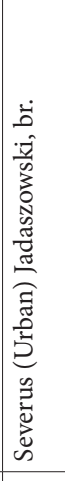 & 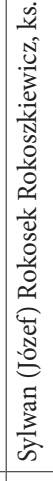 & 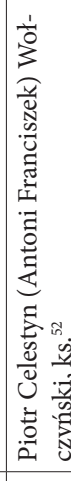 & 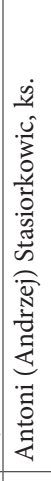 & 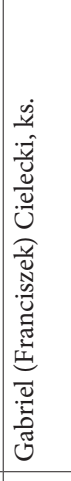 & 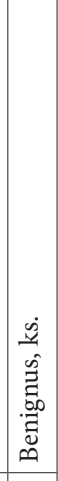 & 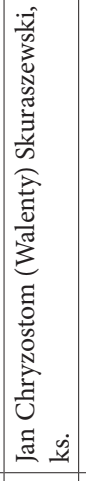 & 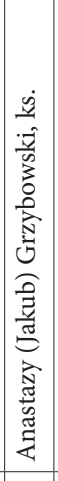 & 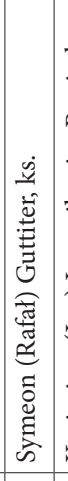 & 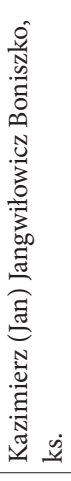 & 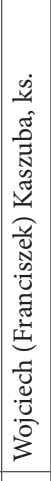 & 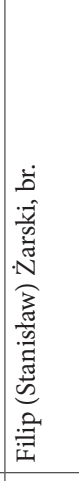 \\
\hline 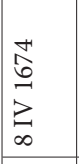 & 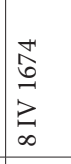 & $\begin{array}{l}\hat{b} \\
\vec{u} \\
\vec{\sim} \\
\vec{\sim}\end{array}$ & 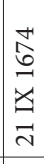 & 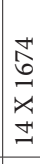 & $\begin{array}{l}\hat{b} \\
\vec{\Xi} \\
\vec{\lambda} \\
\vec{N}\end{array}$ & 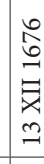 & 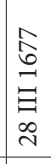 & 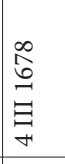 & 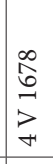 & 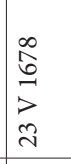 & 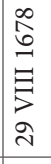 & 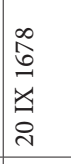 & 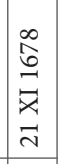 & 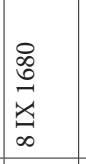 & 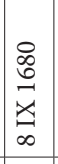 & $\begin{array}{l}0 \\
0 \\
0 \\
\\
- \\
-\end{array}$ & & 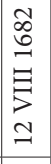 & 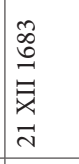 \\
\hline 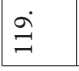 & తి & $\vec{\beth}$ & I & & $\bar{I}$ & $\stackrel{\stackrel{2}{\exists}}{\exists}$ & $\simeq$ & $\widehat{\widehat{I}}$ & $\stackrel{\infty}{\mathbb{I}}$ & ঐิ & 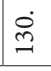 & $\vec{m}$ & $\tilde{n}$ & $\stackrel{\mathscr{m}}{\cong}$ & 岕 & $\mid \begin{array}{c}\stackrel{\leftrightarrow}{-} \\
-1\end{array}$ & 迥 & $\stackrel{\widehat{m}}{-}$ & $\stackrel{\infty}{\infty}$ \\
\hline
\end{tabular}




\begin{tabular}{|c|c|c|c|c|c|c|c|c|c|c|c|c|c|c|c|c|c|c|c|}
\hline$\tilde{m}$ & $\vec{m}$ & $\bumpeq$ & ते & กิ & 녹 & ते & 7 & i & \& & 2 & $\vec{\lambda}$ & $\vec{m}$ & $\hat{\lambda}$ & m & $\vec{m}$ & 2 & $\vec{m}$ & $\stackrel{\Delta}{\Delta}$ & $\simeq$ \\
\hline$\stackrel{2}{\Xi}$ & $\stackrel{2}{ }$ & ని & $\stackrel{ \pm}{\Xi}$ & 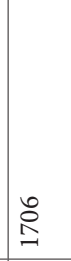 & $\stackrel{I}{I}$ & $\underset{1}{\stackrel{1}{*}}$ & సે & $\underset{\mathbb{N}}{\stackrel{\Xi}{I}}$ & $\stackrel{\cong}{\cong}$ & 足 & $\stackrel{m}{I}$ & 离 & 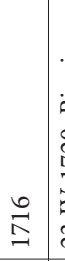 & 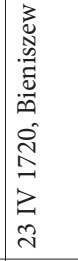 & 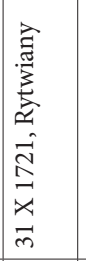 & 空 & $\vec{I}$ & $\stackrel{ \pm}{\Xi}$ & $\stackrel{\Omega}{\Omega}$ \\
\hline 离 & 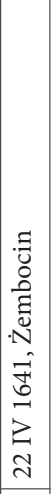 & 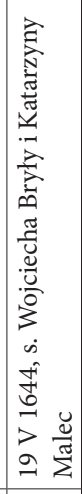 & 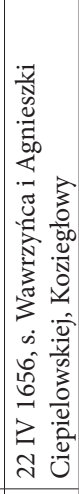 & 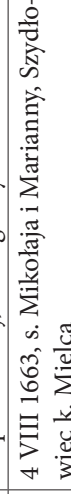 & 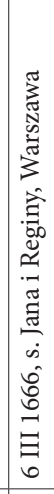 & 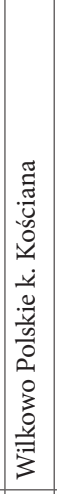 & 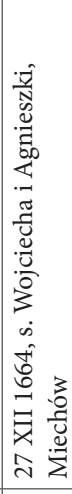 & 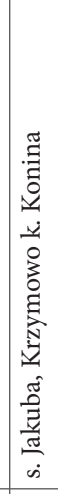 & 鸽 & 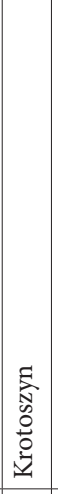 & \begin{tabular}{|l} 
售 \\
总
\end{tabular} & . & 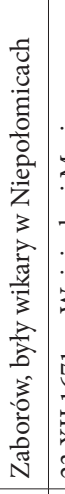 & 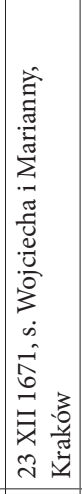 & 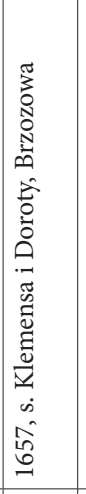 & 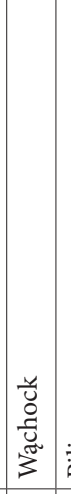 & $\stackrel{\mathscr{\Xi}}{\ddot{\Xi}}$ & : & 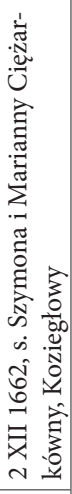 \\
\hline 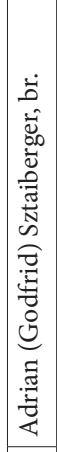 & 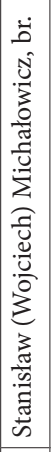 & 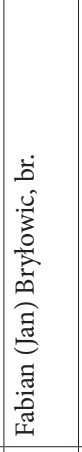 & 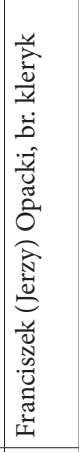 & 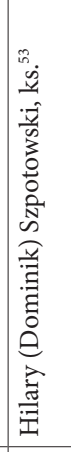 & 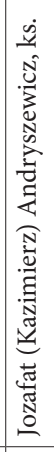 & 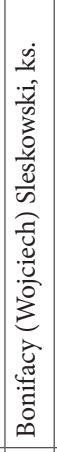 & 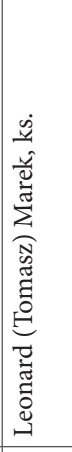 & 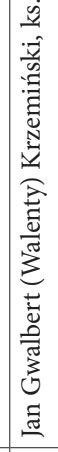 & 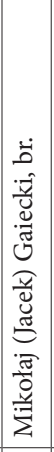 & 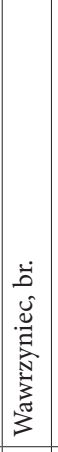 & 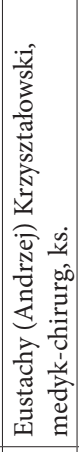 & 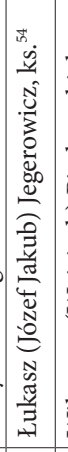 & 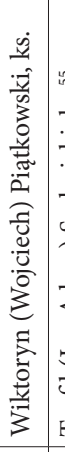 & 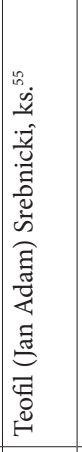 & 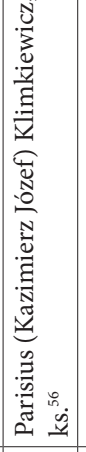 & : & 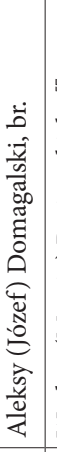 & 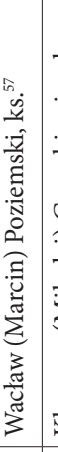 & 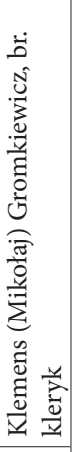 \\
\hline 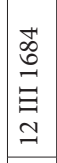 & $\begin{array}{l}\overrightarrow{1} \\
0 \\
0 \\
\vdots \\
z \\
\end{array}$ & 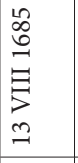 & 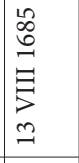 & 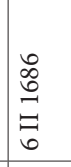 & $\begin{array}{l}\infty \\
\stackrel{0}{0} \\
\end{array}$ & 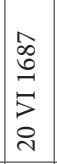 & 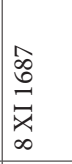 & 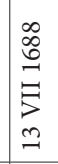 & 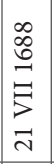 & 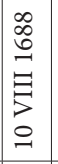 & 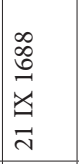 & 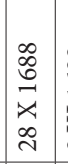 & 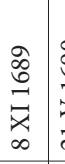 & 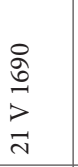 & 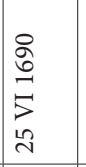 & 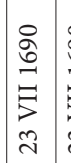 & 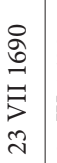 & 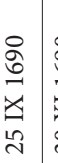 & 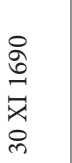 \\
\hline$\vec{c}$ & $\exists$ & $\exists$ & $\exists$ & $\stackrel{\Re}{\exists}$ & $\exists$ & 悉 & İ & 㼛 & $\stackrel{\infty}{ \pm}$ & İ & in & İ & ș & $\stackrel{\Omega}{\Omega}$ & 兽 & 令 & $\begin{array}{l}\dot{0} \\
\stackrel{2}{2}\end{array}$ & in & $\stackrel{\infty}{\stackrel{\infty}{n}}$ \\
\hline
\end{tabular}


Bielany - ulubione miejsce Krakowa...

\begin{tabular}{|c|c|c|c|c|c|c|c|c|c|c|c|c|c|c|c|c|c|}
\hline H' & in & $\stackrel{\infty}{m}$ & $\stackrel{\sim}{\sim}$ & $\stackrel{\infty}{+}$ & กิ & $\hat{n}$ & $\Xi$ & in & 10 & F & i & in & $\tilde{n}$ & $\stackrel{\infty}{i n}$ & $\stackrel{\sim}{\sim}$ & $\stackrel{m}{m}$ & $\stackrel{\sim}{\sim}$ \\
\hline 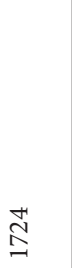 & 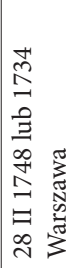 & ָิ & $\stackrel{ }{\Xi}$ & $\underset{I}{\exists}$ & 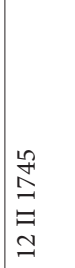 & 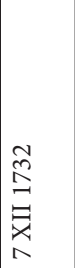 & $\stackrel{\infty}{\stackrel{2}{\beth}}$ & 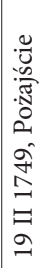 & $\stackrel{\stackrel{2}{I}}{ }$ & $\stackrel{\infty}{\bumpeq}$ & 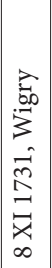 & $\stackrel{\vec{n}}{\underline{n}}$ & 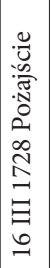 & 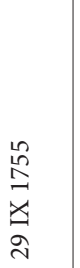 & $\overrightarrow{\mathbb{N}}$ & 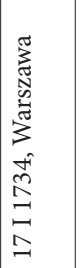 & 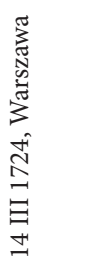 \\
\hline 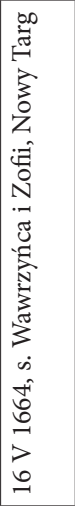 & 总 & 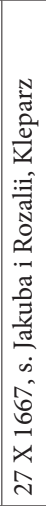 & 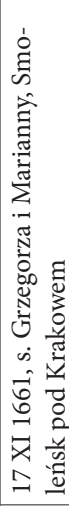 & 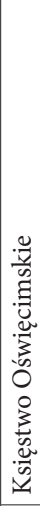 & 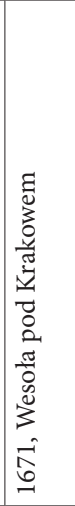 & 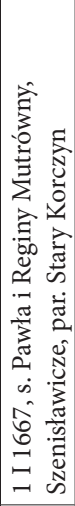 & 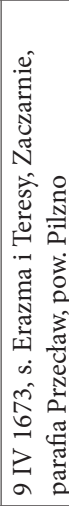 & 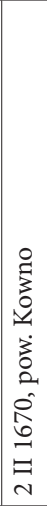 & 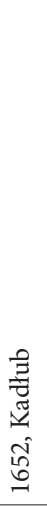 & 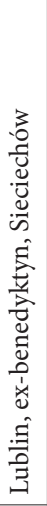 & 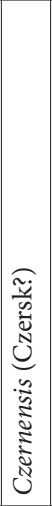 & 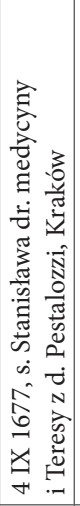 & 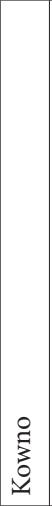 & 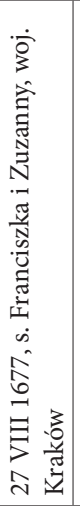 & 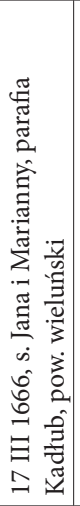 & 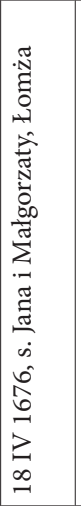 & 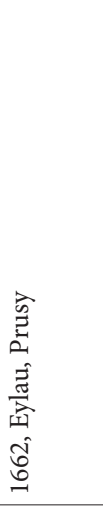 \\
\hline 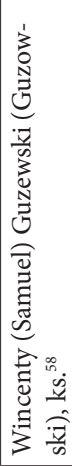 & 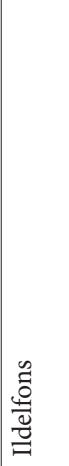 & 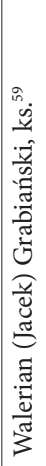 & 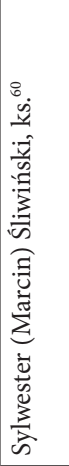 & 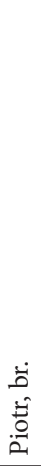 & 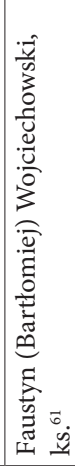 & 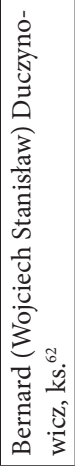 & 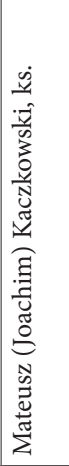 & 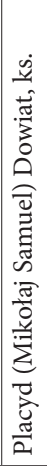 & 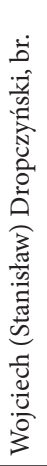 & 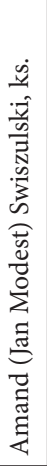 & 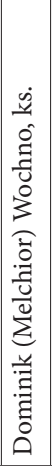 & 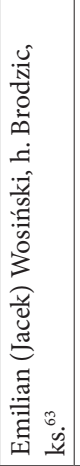 & 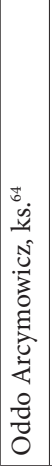 & 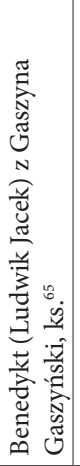 & 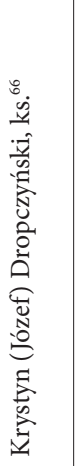 & 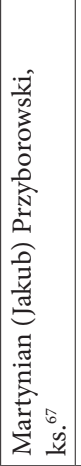 & 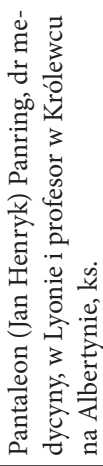 \\
\hline $\begin{array}{l}\overrightarrow{\widehat{a}} \\
\overrightarrow{-} \\
\vec{\forall}\end{array}$ & 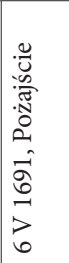 & 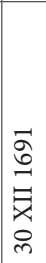 & 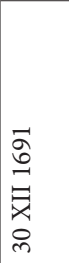 & $\begin{array}{l}\hat{a} \\
\underline{\sigma} \\
\\
\stackrel{0}{v}\end{array}$ & $\begin{array}{l}\stackrel{+}{\sigma} \\
\underset{\Xi}{\Xi} \\
\infty \\
=\end{array}$ & 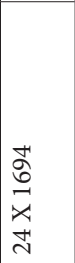 & 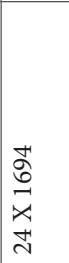 & 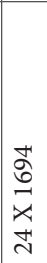 & 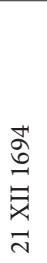 & 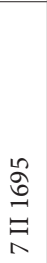 & 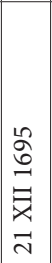 & 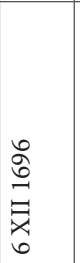 & 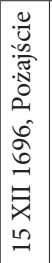 & 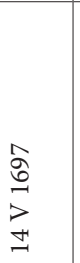 & 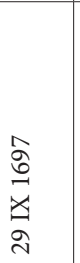 & 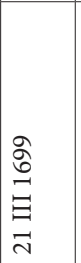 & 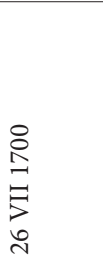 \\
\hline in & $\dot{8}$ & ن. & త్ర & $\ddot{\theta}$ & త્ర & ப் & $\dot{0}$ & $\stackrel{0}{0}$ & $\infty_{0}^{\infty}$ & ல் & $\dot{\Omega}$ & I & $\stackrel{i}{I}$ & $\stackrel{\stackrel{N}{I}}{=}$ & $\stackrel{\text { İ }}{\text { I }}$ & $\stackrel{20}{I}$ & $\stackrel{0}{\stackrel{0}{2}}$ \\
\hline
\end{tabular}




\begin{tabular}{|c|c|c|c|c|c|c|c|c|c|c|c|c|c|c|c|c|c|c|}
\hline ๗ు & $\infty$ & ి & ঐे & 우 & $\ddot{m}$ & n & 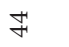 & \& & $\stackrel{\Perp}{\sim}$ & $\ddot{m}$ & 구 & $\Lambda$ & 아 & & $\stackrel{\infty}{\sim}$ & $\hat{\sim}$ & in & $F$ \\
\hline$\stackrel{\cong}{\stackrel{\Perp}{=}}$ & $\stackrel{و}{\stackrel{2}{2}}$ & $\overrightarrow{\mathbb{I}}$ & 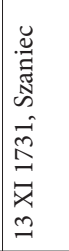 & 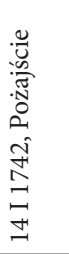 & 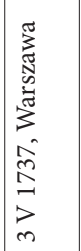 & 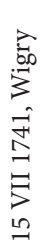 & 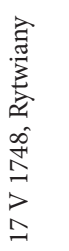 & 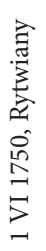 & 苍 & 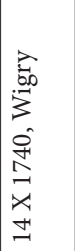 & 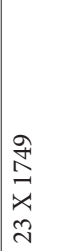 & 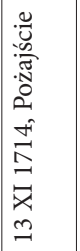 & 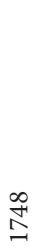 & 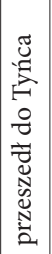 & 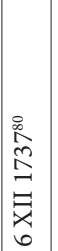 & 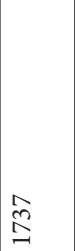 & 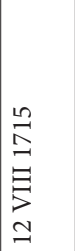 & $\stackrel{\vec{n}}{\stackrel{n}{=}}$ \\
\hline 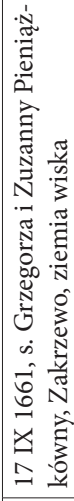 & 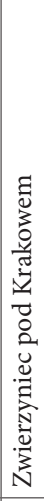 & 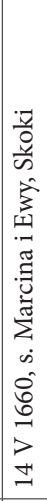 & 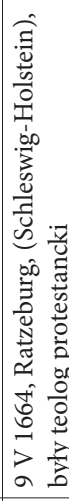 & 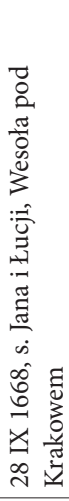 & 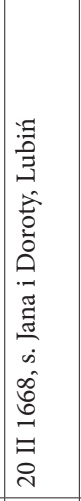 & 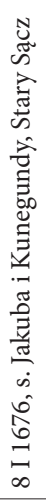 & 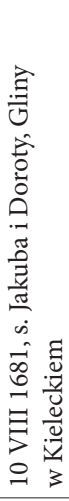 & 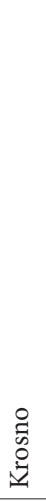 & 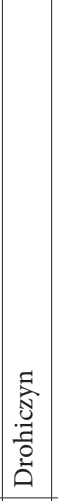 & 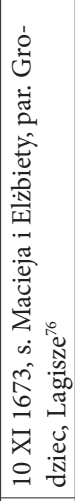 & 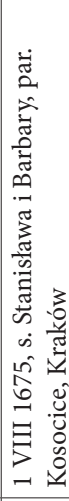 & 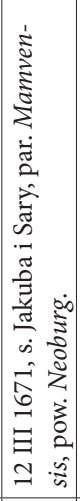 & 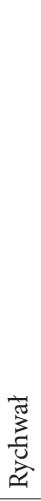 & 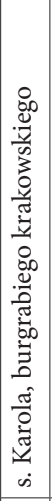 & 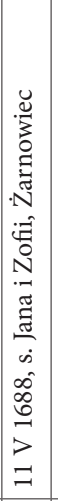 & 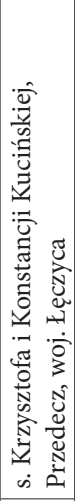 & 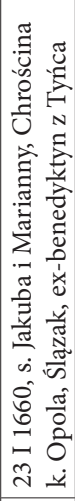 & 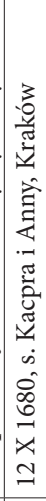 \\
\hline 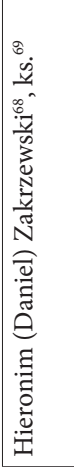 & 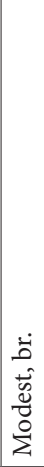 & 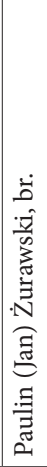 & 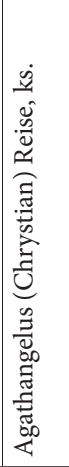 & 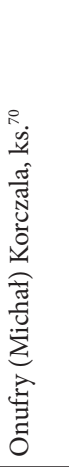 & 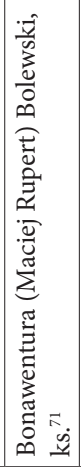 & 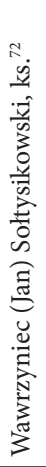 & 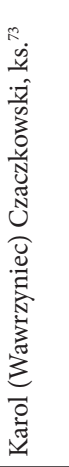 & 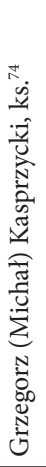 & 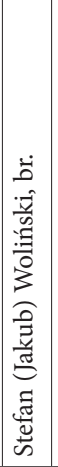 & 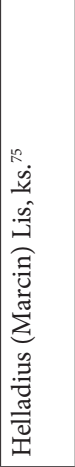 & 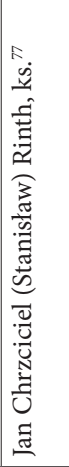 & 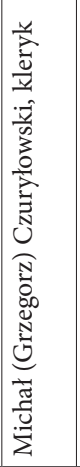 & 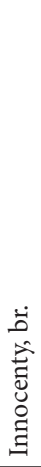 & 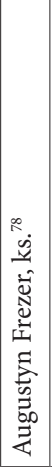 & 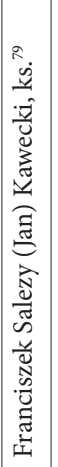 & 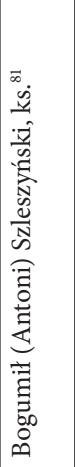 & 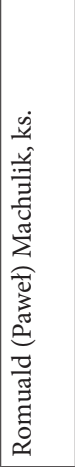 & 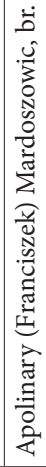 \\
\hline $\begin{array}{l}\overrightarrow{0} \\
\stackrel{2}{2} \\
2 \\
0\end{array}$ & 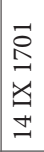 & 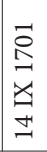 & 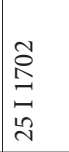 & 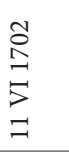 & 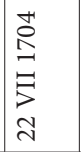 & 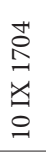 & 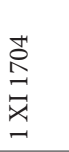 & 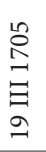 & $\begin{array}{l}8 \\
\vdots \\
\vdots \\
\ddots\end{array}$ & 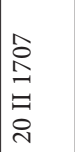 & $\begin{array}{l}\hat{O} \\
\stackrel{1}{2} \\
\stackrel{2}{N} \\
\stackrel{\sim}{n}\end{array}$ & 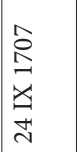 & 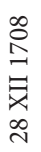 & 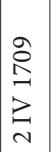 & 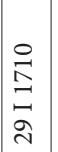 & 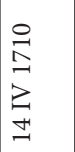 & 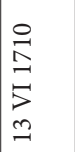 & 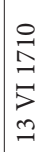 \\
\hline$\underline{\mathrm{N}}$ & $\stackrel{\infty}{\stackrel{\infty}{\Xi}}$ & 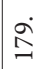 & $\stackrel{\circ}{\circ}$ & $\underset{\sim}{-\infty}$ & $\stackrel{\infty}{\infty}$ & $\stackrel{\infty}{\infty}$ & $\stackrel{\infty}{\sim}$ & $\stackrel{10}{\infty}$ & $\begin{array}{l}\dot{\infty} \\
\stackrel{0}{ }\end{array}$ & $\stackrel{\infty}{\rightarrow}$ & 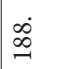 & $\stackrel{\circ}{\circ}$ & & $\bar{\Xi}$ & ฮ่ & $\stackrel{2}{2}$ & த் & $\stackrel{\text { ハ் }}{\Omega}$ \\
\hline
\end{tabular}




\begin{tabular}{|c|c|c|c|c|c|c|c|c|c|c|c|c|c|c|c|c|c|c|c|}
\hline in & & 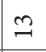 & 10 & $\hat{n}$ & n & & & ले & શิ & $\stackrel{\infty}{\sim}$ & $\stackrel{\text { ণ }}{ }$ & $\stackrel{\infty}{\sim}$ & $\hat{\sim}$ & $\simeq$ & $\stackrel{\infty}{\sim}$ & $a$ & $\infty$ & F & $\exists$ \\
\hline$\stackrel{n}{\stackrel{2}{\Xi}}$ & & 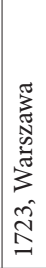 & $\begin{array}{l}\stackrel{0}{N} \\
\stackrel{7}{>} \\
\sim \\
\sim\end{array}$ & 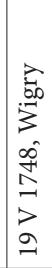 & 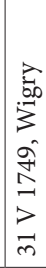 & & & $\stackrel{\vec{n}}{=}$ & 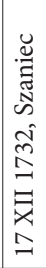 & 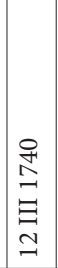 & 곤 & 옫 & 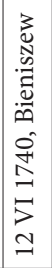 & 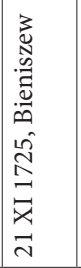 & 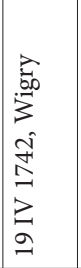 & $\underset{\sim}{\stackrel{\sim}{N}}$ & 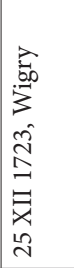 & 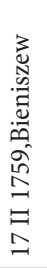 & 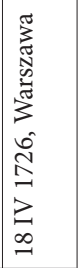 \\
\hline 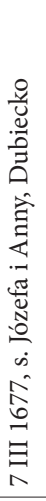 & & 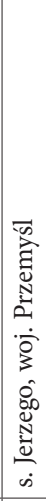 & 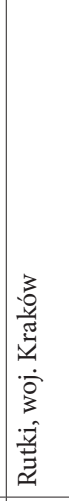 & 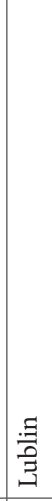 & 节 & 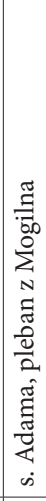 & 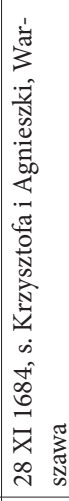 & 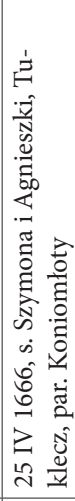 & 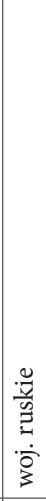 & 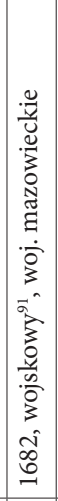 & 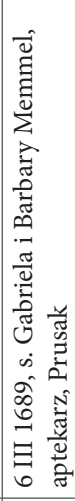 & 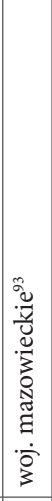 & 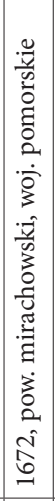 & 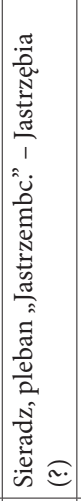 & 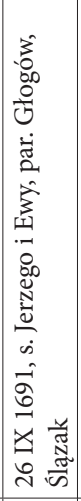 & 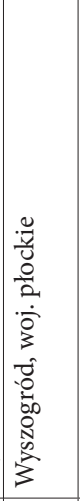 & 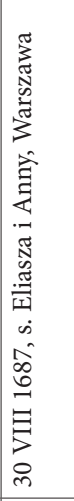 & 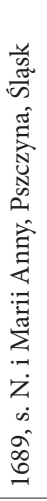 & 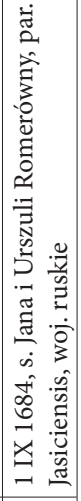 \\
\hline 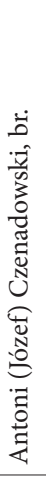 & 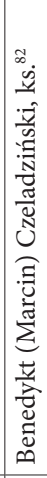 & 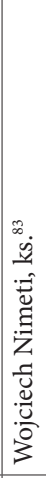 & 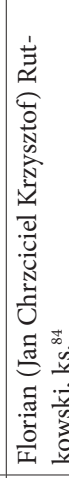 & 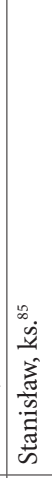 & 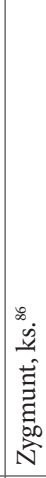 & 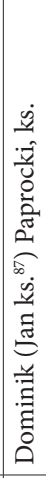 & 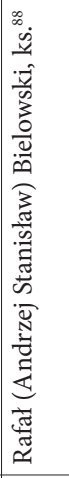 & 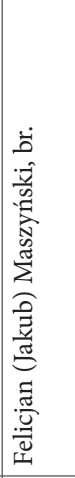 & 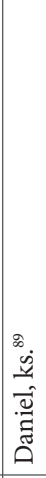 & 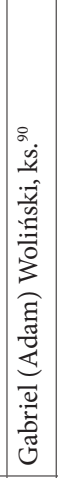 & 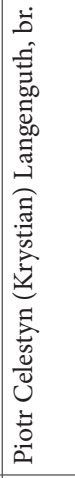 & 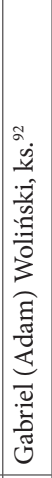 & 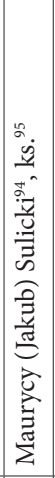 & 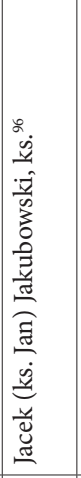 & 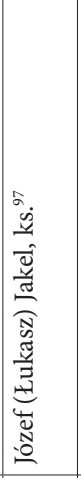 & 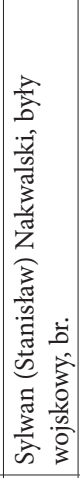 & 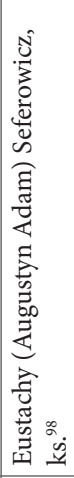 & 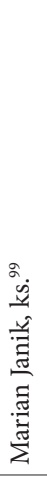 & 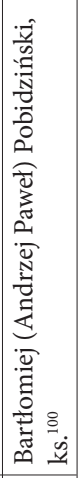 \\
\hline 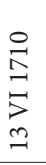 & 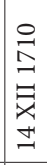 & $\begin{array}{l}\vec{\Sigma} \\
\underset{\sim}{\beth} \\
\stackrel{\sim}{a}\end{array}$ & 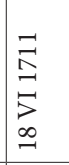 & 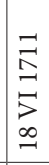 & 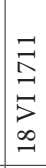 & $\begin{array}{l}\exists \\
\Xi \\
\vec{u} \\
\exists\end{array}$ & 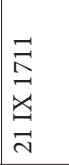 & 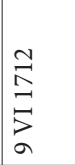 & 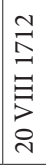 & 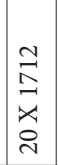 & 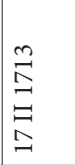 & 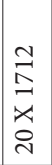 & $\begin{array}{l}m \\
I \\
D \\
2 \\
\stackrel{n}{N}\end{array}$ & 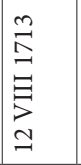 & 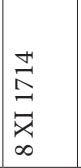 & $\begin{array}{l}\stackrel{2}{2} \\
\stackrel{\Xi}{\Xi} \\
\stackrel{\infty}{二}\end{array}$ & $\begin{array}{l}n \\
\text { 足 } \\
\text { 采 } \\
\text { N }\end{array}$ & 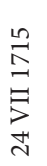 & 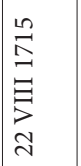 \\
\hline$\stackrel{\circ}{2}$ & $\hat{\Omega}$ & $\stackrel{\circ}{\stackrel{2}{\varrho}}$ & & $\dot{\mathscr{D}}$ & 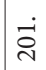 & ટ્่ & $\dot{\sim}$ & ঙ્ণ & นึ่ & ڤ્ণ & 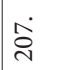 & $\stackrel{\infty}{\stackrel{0}{\sim}}$ & ڤें & $\stackrel{\dot{\sim}}{\sim}$ & $\dot{\vec{\sim}}$ & $\stackrel{\dot{a}}{\sim}$ & $\stackrel{\sim}{\vec{\sim}}$ & $\underset{\sim}{\stackrel{\sim}{\sim}}$ & $\stackrel{i n}{\sim}$ \\
\hline
\end{tabular}




\begin{tabular}{|c|c|c|c|c|c|c|c|c|c|c|c|c|c|c|c|c|c|}
\hline 응 & $\hat{n}$ & 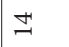 & $\exists$ & $\hat{m}$ & हो & $\stackrel{+}{\sim}$ & ले & $\stackrel{\sim}{\sim}$ & $a$ & in & in & F & in & in & P & $\stackrel{0}{-1}$ & $\stackrel{10}{\sim}$ \\
\hline 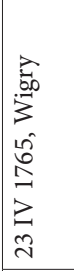 & $\begin{array}{l}\text { ñ } \\
\stackrel{-}{二} \\
\vec{\sim} \\
\vec{\sim}\end{array}$ & 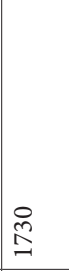 & 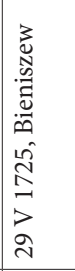 & 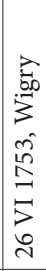 & 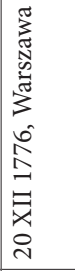 & 고 & 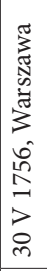 & 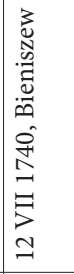 & 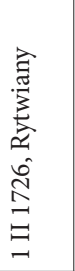 & 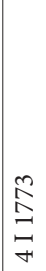 & 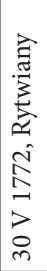 & 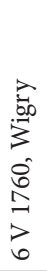 & 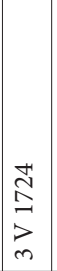 & 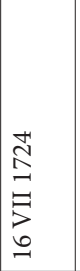 & $\begin{array}{l}\frac{a}{2} \\
\stackrel{1}{2} \\
z \\
\text { v }\end{array}$ & 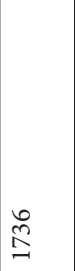 & $\stackrel{\stackrel{n}{\Omega}}{\cong}$ \\
\hline 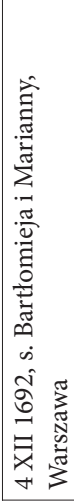 & 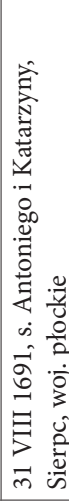 & 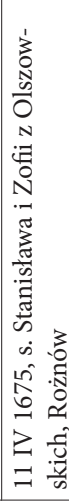 & 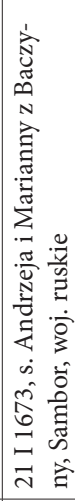 & 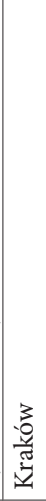 & 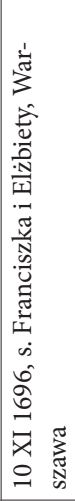 & 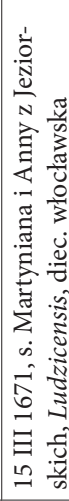 & 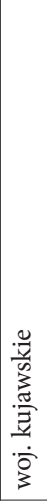 & 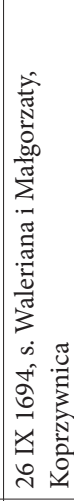 & 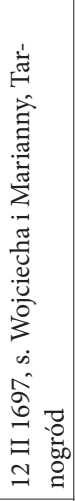 & 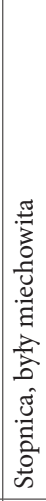 & 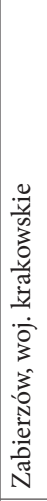 & 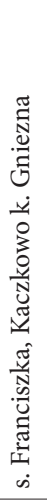 & 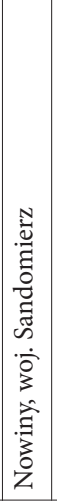 & 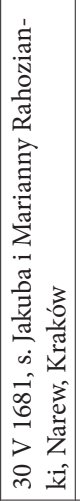 & 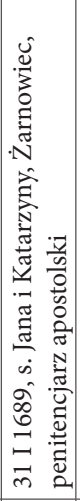 & 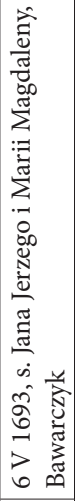 & 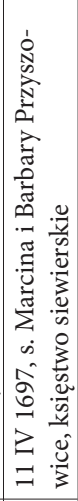 \\
\hline 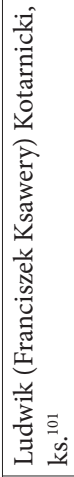 & 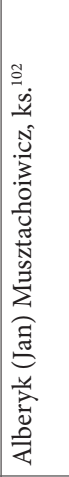 & 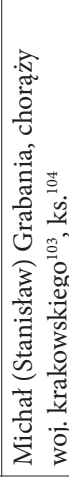 & 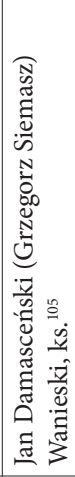 & 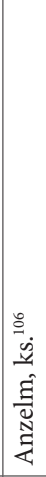 & 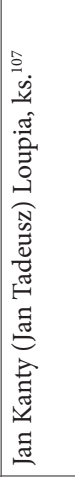 & 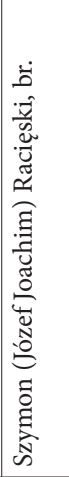 & 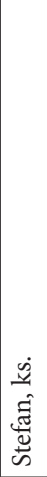 & 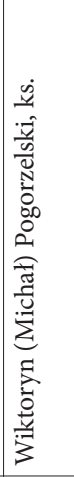 & 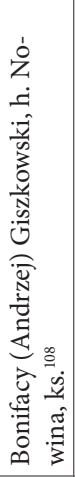 & 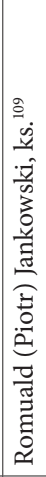 & 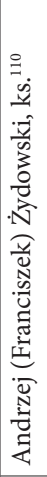 & 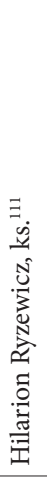 & 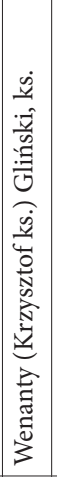 & 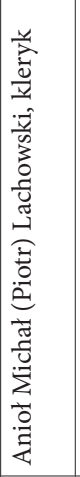 & 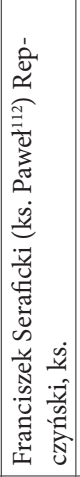 & 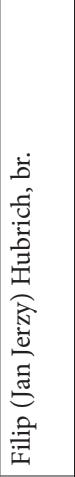 & 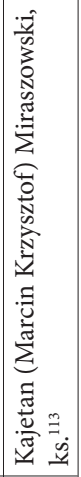 \\
\hline 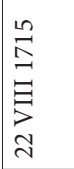 & 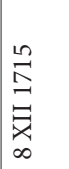 & $\begin{array}{l}0 \\
\stackrel{1}{二} \\
\Xi \\
\stackrel{\infty}{二} \\
\infty\end{array}$ & $\begin{array}{l}\text { 兄 } \\
\text { 严 } \\
\text { 子 }\end{array}$ & 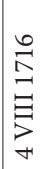 & $\begin{array}{l}\cong \\
\Xi \\
\Xi \\
\Xi \\
\Xi\end{array}$ & 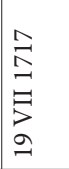 & 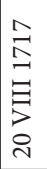 & 昙 & $\begin{array}{l}\stackrel{ }{\triangle} \\
\underset{\Delta}{\triangle}\end{array}$ & 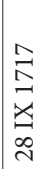 & 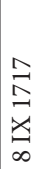 & 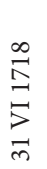 & 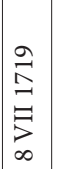 & 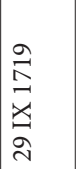 & 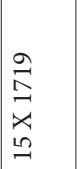 & 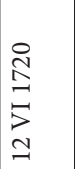 & 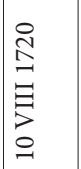 \\
\hline $\begin{array}{l}\dot{\vec{v}} \\
\vec{\sim}\end{array}$ & $\vec{\sim}$ & $\underset{\vec{N}}{\stackrel{\infty}{N}}$ & $\overrightarrow{\vec{v}}$ & तె่ & $\overrightarrow{\mathrm{N}}$ & तี & $\stackrel{\sim}{\sim}$ & $\tilde{N}$ & 岇 & $\vec{\sim}$ & $\overrightarrow{\mathrm{N}}$ & $\widetilde{\sim}$ & సें & $\dot{\sim}$ & $\vec{\sim}$ & तె & $\ddot{\sim}$ \\
\hline
\end{tabular}


Bielany - ulubione miejsce Krakowa...

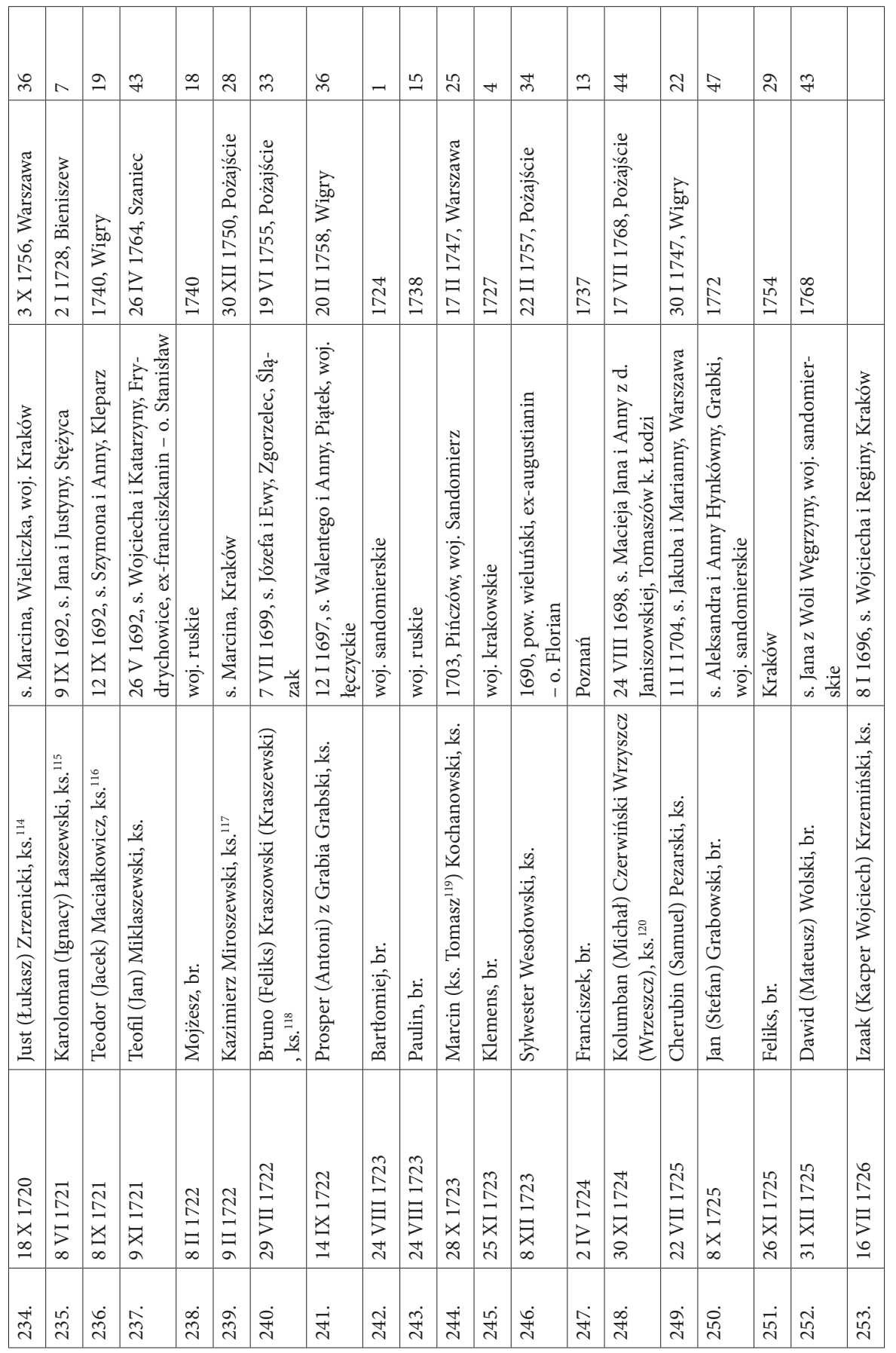




\begin{tabular}{|c|c|c|c|c|c|c|c|c|c|c|c|c|c|c|c|c|c|c|c|}
\hline$\stackrel{\infty}{\stackrel{1}{2}}$ & i & $\exists$ & $\stackrel{\infty}{\sim}$ & ते & mे & $\approx$ & $\stackrel{\infty}{\infty}$ & $\cong$ & $\sigma$ & $\alpha$ & $\stackrel{i}{2}$ & $\stackrel{\infty}{+} \underset{\infty}{\infty}$ & $\underset{\sim}{\infty}$ & 0 & $\tilde{m}$ & m) & 9 & & ले \\
\hline 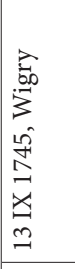 & $\begin{array}{l}\hat{R} \\
\stackrel{2}{\Xi} \\
\exists \\
\forall\end{array}$ & 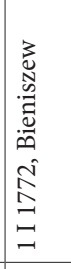 & 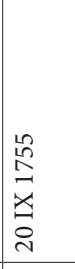 & 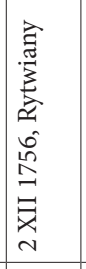 & 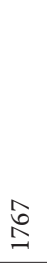 & $\begin{array}{l}9 \\
\stackrel{9}{I} \\
=\end{array}$ & $\begin{array}{l}\frac{1}{8} \\
\stackrel{-1}{-1}\end{array}$ & 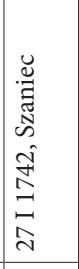 & 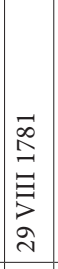 & 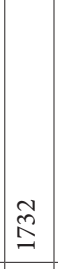 & 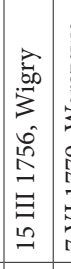 & 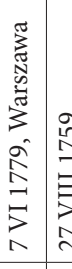 & 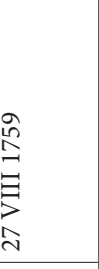 & 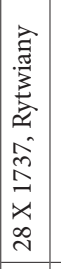 & \begin{tabular}{l} 
\\
8 \\
\hdashline \\
\hdashline
\end{tabular} & 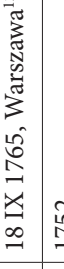 & . & & 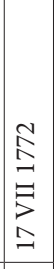 \\
\hline 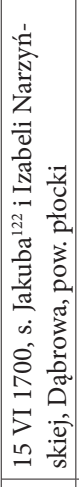 & 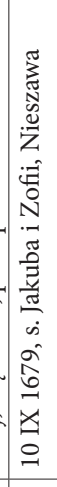 & 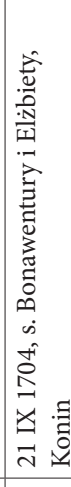 & 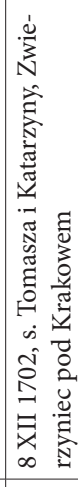 & 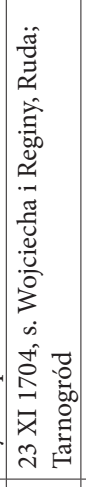 & \begin{tabular}{|l}
$\mid$ \\
\\
3 \\
0 \\
0 \\
0 \\
0 \\
0 \\
0 \\
0
\end{tabular} & $\frac{8}{\frac{9}{3}}$ & 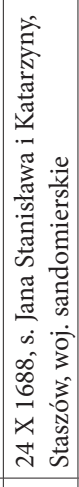 & 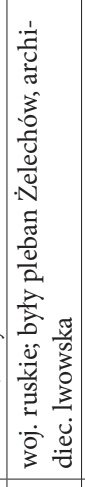 & 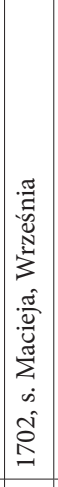 & 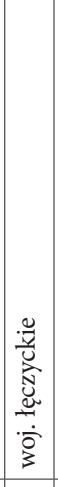 & 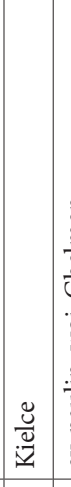 & 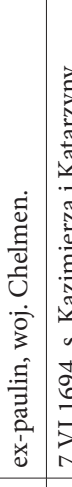 & 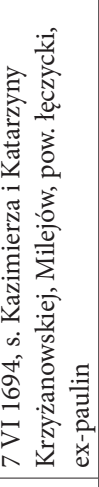 & 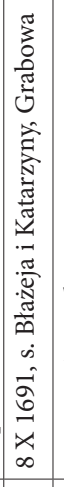 & 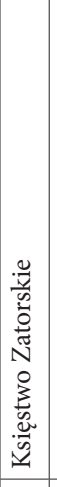 & 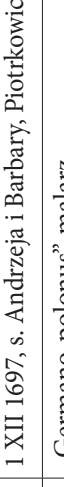 & 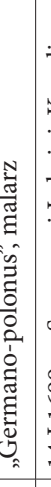 & 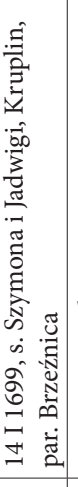 & 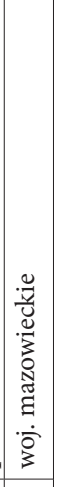 \\
\hline 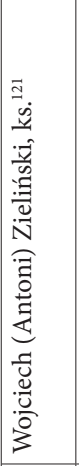 & 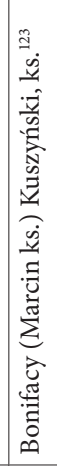 & 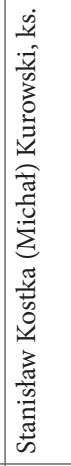 & 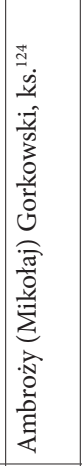 & 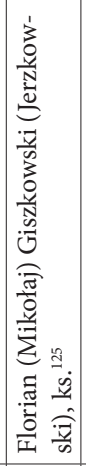 & $\begin{array}{l}\dot{3} \\
\dot{0} \\
\frac{3}{3} \\
\frac{3}{2}\end{array}$ & 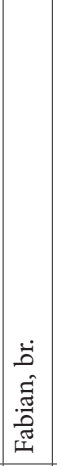 & 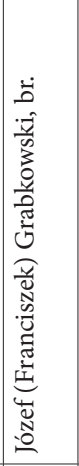 & 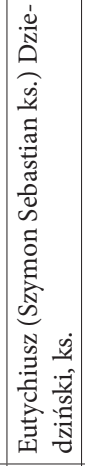 & 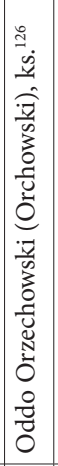 & 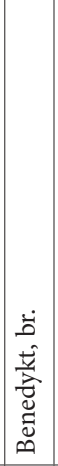 & 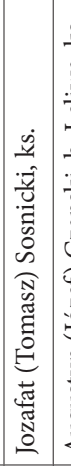 & 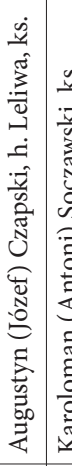 & 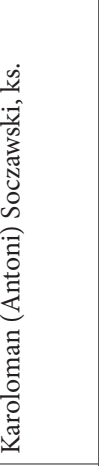 & 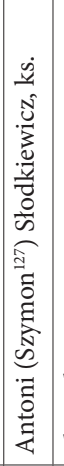 & 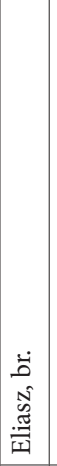 & 童 & 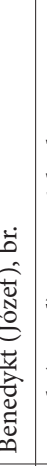 & 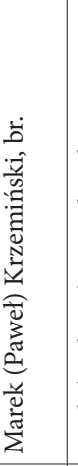 & 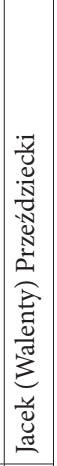 \\
\hline 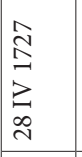 & 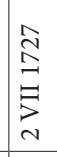 & 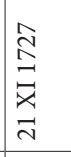 & 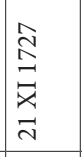 & 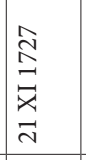 & 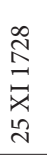 & 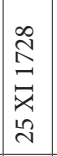 & 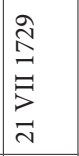 & 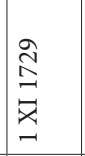 & $\begin{array}{l}\stackrel{a}{\grave{N}} \\
\vec{\Xi} \\
- \\
-\end{array}$ & 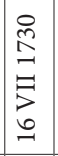 & 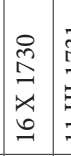 & 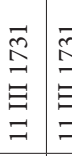 & $\begin{array}{l}\vec{n} \\
\stackrel{\Xi}{\Xi} \\
\Xi\end{array}$ & $\begin{array}{l}\overrightarrow{0} \\
\stackrel{\vec{D}}{\Xi} \\
\Xi \\
\Xi\end{array}$ & 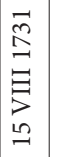 & 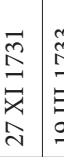 & 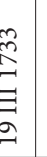 & & 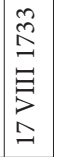 \\
\hline ث્ત & 岂 & $\begin{array}{l}\mathscr{\imath} \\
\text { הి }\end{array}$ & 命 & 离 & 幽 & $\begin{array}{l}8 \\
0 \\
\text { in }\end{array}$ & $\overrightarrow{\mathrm{d}}$ & กิ & 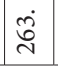 & $\begin{array}{l}\text { di } \\
\text { | }\end{array}$ & 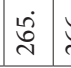 & $\begin{array}{lll}0 \\
0\end{array}$ & ¿े & 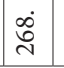 & ồ & ì & $\vec{v}$ & ત્ & 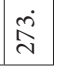 \\
\hline
\end{tabular}


Bielany - ulubione miejsce Krakowa...

\begin{tabular}{|c|c|c|c|c|c|c|c|c|c|c|c|c|c|c|c|c|c|}
\hline$\stackrel{\sharp}{\sim}$ & $\exists$ & 10 & $\underset{\sim}{2}$ & $\underset{\sim}{\sim}$ & त & $\underset{\sim}{*}$ & $\stackrel{\infty}{\sim}$ & $\vec{\sim}$ & F & "ె & भ & & ले & ले & లె & $\stackrel{\infty}{\sim}$ & $\mathscr{F}$ \\
\hline 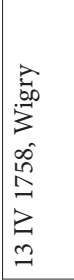 & 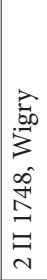 & $\begin{array}{l}\stackrel{2}{1} \\
\text { 齐 } \\
2 \\
=\end{array}$ & $\begin{array}{l}\vec{b} \\
\triangleq \\
\Xi \\
\vdots \\
\infty \\
\sim\end{array}$ & $\stackrel{\overrightarrow{0}}{\stackrel{-}{-}}$ & 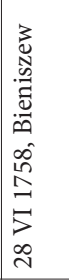 & $\vec{\jmath}$ & $\begin{array}{l}\qquad 8 \\
气\end{array}$ & $\stackrel{\infty}{\stackrel{\infty}{\Lambda}}$ & 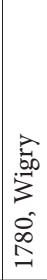 & 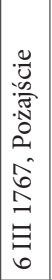 & 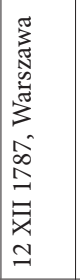 & & $\stackrel{\infty}{\stackrel{\infty}{N}}$ & $\stackrel{\infty}{\stackrel{\infty}{人}}$ & $\stackrel{ }{\Sigma}$ & 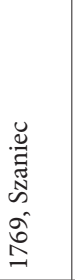 & 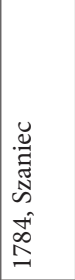 \\
\hline 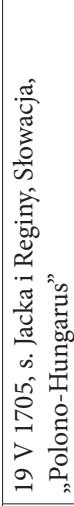 & 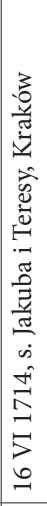 & 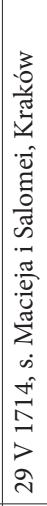 & 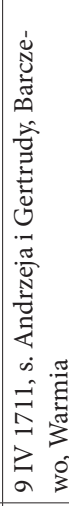 & 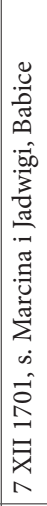 & 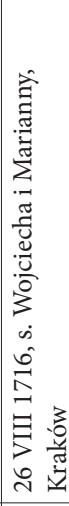 & 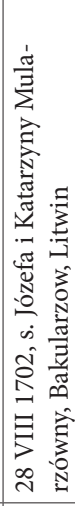 & 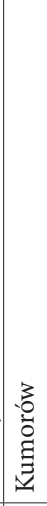 & 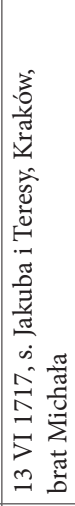 & 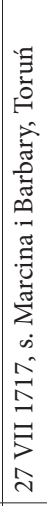 & 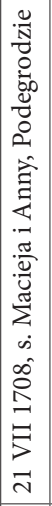 & 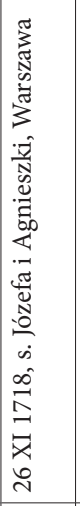 & 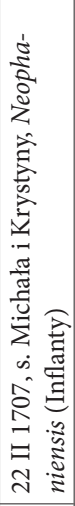 & 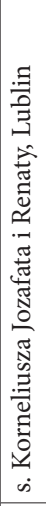 & 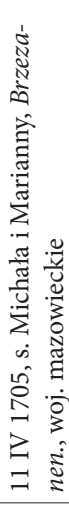 & 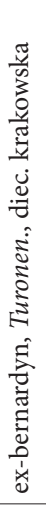 & 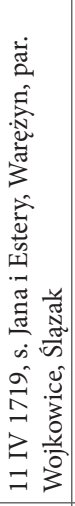 & 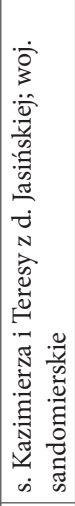 \\
\hline 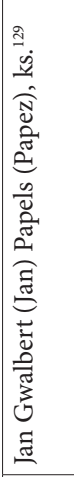 & 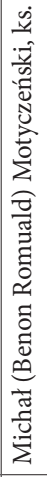 & 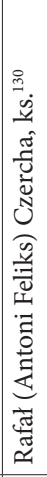 & 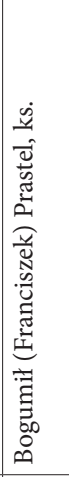 & 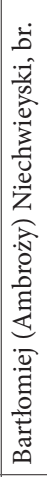 & 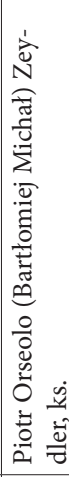 & 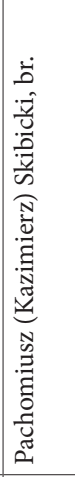 & 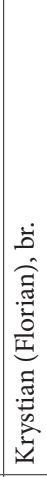 & 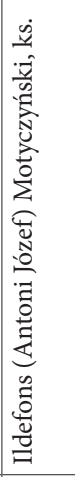 & 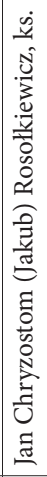 & 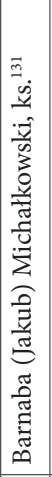 & 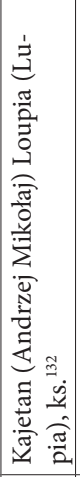 & 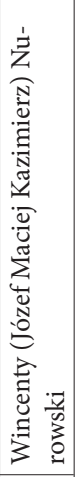 & 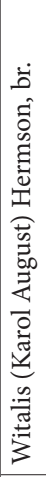 & 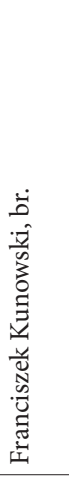 & 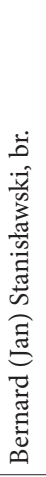 & 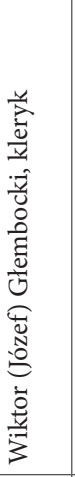 & 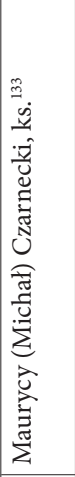 \\
\hline 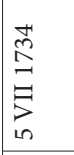 & $\begin{array}{l}\stackrel{H}{N} \\
\stackrel{\Perp}{\Perp} \\
=\end{array}$ & 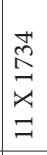 & 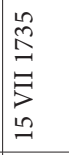 & 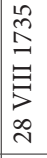 & 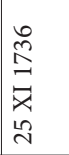 & 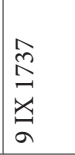 & 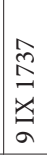 & $\begin{array}{l}\hat{\sim} \\
\stackrel{2}{二} \\
\vec{x} \\
\stackrel{n}{\sim}\end{array}$ & 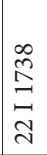 & 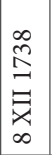 & 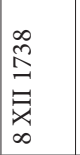 & 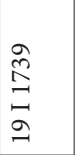 & 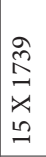 & 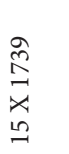 & 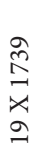 & 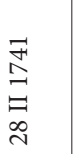 & $\begin{array}{l}\text { F } \\
\text { 三 } \\
\text { 寻 } \\
m\end{array}$ \\
\hline 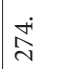 & 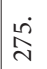 & ڤ̊ & 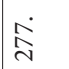 & $\stackrel{\infty}{\stackrel{\infty}{\sim}}$ & సે & $\dot{\sim}$ & $\vec{\infty}$ & ָ) & 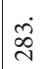 & 就 & $\stackrel{\infty}{\sim}$ & $\begin{array}{l}\dot{0} \\
\stackrel{0}{\sim}\end{array}$ & 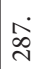 & $\begin{array}{l}\infty \\
\stackrel{\infty}{\sim}\end{array}$ & वें & ஓें & $\overline{\widehat{N}}$ \\
\hline
\end{tabular}




\begin{tabular}{|c|c|c|c|c|c|c|c|c|c|c|c|c|c|c|c|c|c|}
\hline$F$ & $\vec{\sim}$ & $\stackrel{+}{\sim}$ & $\stackrel{\sim}{\sim}$ & 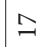 & $\cong$ & $\stackrel{\sim}{\sim}$ & 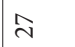 & ले & 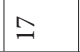 & $\vec{\sim}$ & $\stackrel{\bullet}{\sim}$ & & $\stackrel{m}{m}$ & \& & $\stackrel{\infty}{m}$ & & भे \\
\hline$\stackrel{\infty}{\stackrel{\infty}{=}}$ & 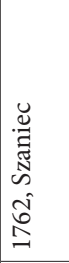 & $\begin{array}{l}20 \\
\stackrel{2}{-}\end{array}$ & 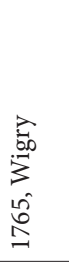 & $\stackrel{\infty}{\stackrel{\infty}{\Lambda}}$ & 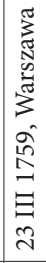 & $\stackrel{\infty}{\varrho}$ & $\begin{array}{l}\hat{2} \\
\stackrel{1}{2}\end{array}$ & 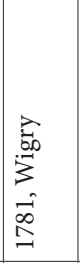 & 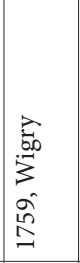 & 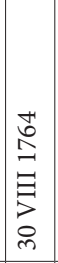 & 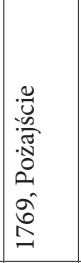 & & 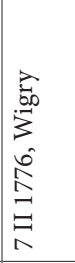 & 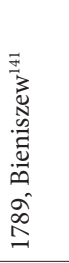 & 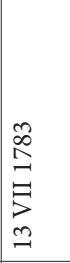 & & 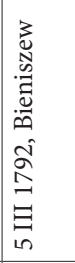 \\
\hline 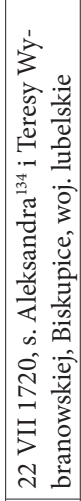 & 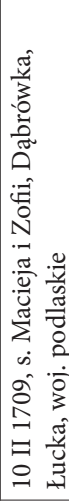 & 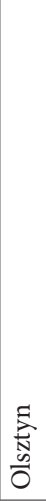 & 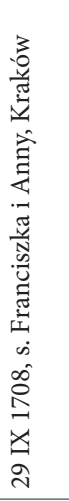 & 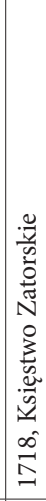 & 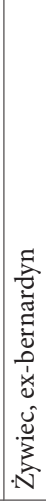 & 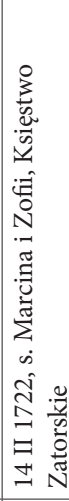 & 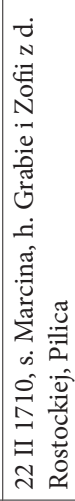 & 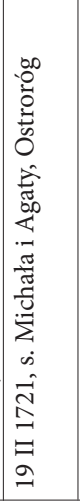 & 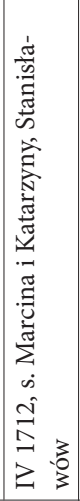 & 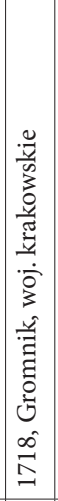 & 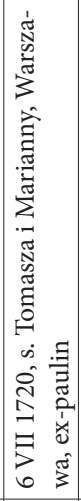 & 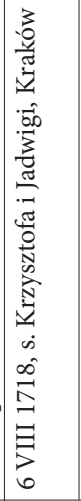 & 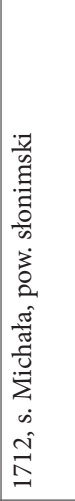 & 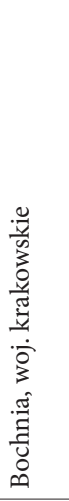 & 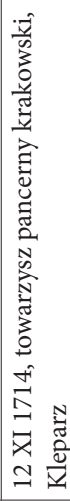 & 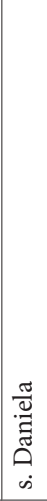 & 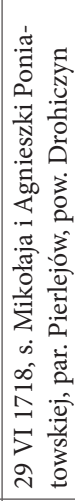 \\
\hline 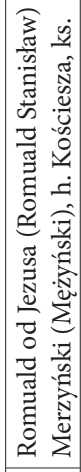 & 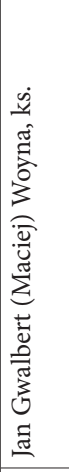 & 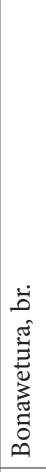 & 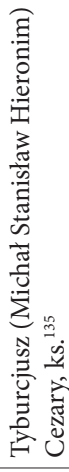 & 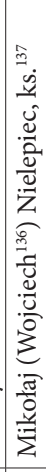 & 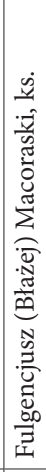 & 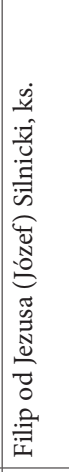 & 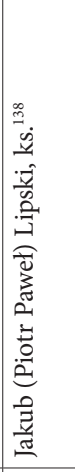 & 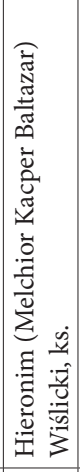 & 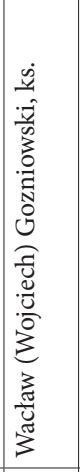 & 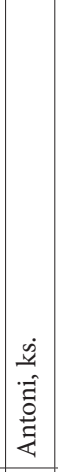 & 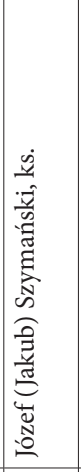 & 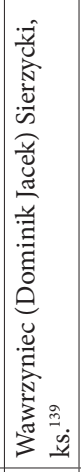 & 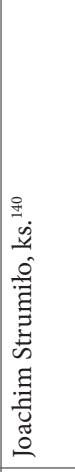 & 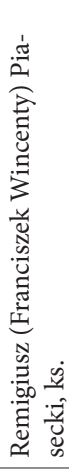 & 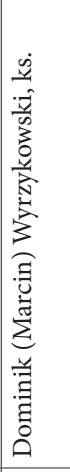 & 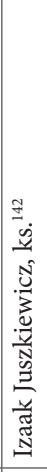 & 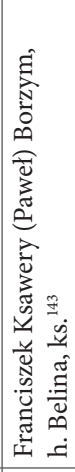 \\
\hline 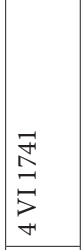 & 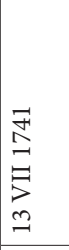 & 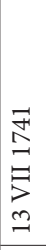 & 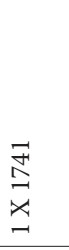 & 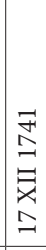 & 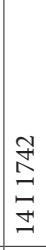 & $\begin{array}{l}\text { ㄱ } \\
\stackrel{2}{7} \\
\underset{m}{2}\end{array}$ & 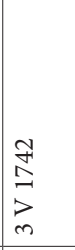 & 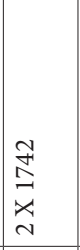 & 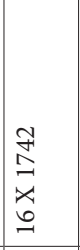 & 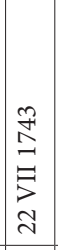 & 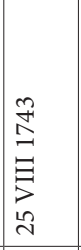 & 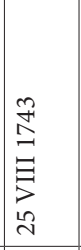 & 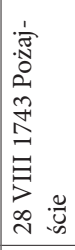 & 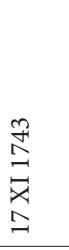 & 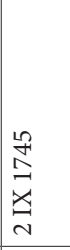 & 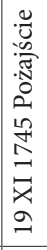 & 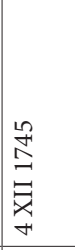 \\
\hline নิ & ळે & ন্রি & ஷू & ¿ें & $\widehat{\grave{N}}$ & 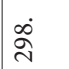 & ন & 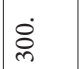 & 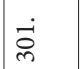 & ర్ల & 命 & 焉 & 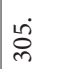 & ठ্ల & 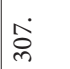 & 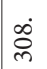 & 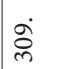 \\
\hline
\end{tabular}


Bielany - ulubione miejsce Krakowa...

\begin{tabular}{|c|c|c|c|c|c|c|c|c|c|c|c|c|c|c|c|c|c|c|c|}
\hline & ले & to & ले & $\tilde{6}$ & $\mathbb{F}$ & m゙ & $\stackrel{\infty}{\sim}$ & $\vec{m}$ & F & $\simeq$ & $\vec{m}$ & లి & $m$ & 0 & 으 & m゙ & 아 & & లి \\
\hline & 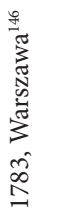 & న్ & 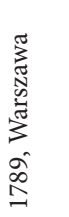 & 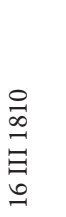 & 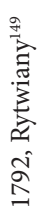 & 芯 & 点 & $\begin{array}{l}\infty \\
\stackrel{D}{\beth}\end{array}$ & $\stackrel{\curvearrowright}{\Omega}$ & 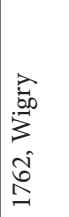 & 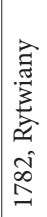 & 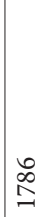 & $\begin{array}{l}\infty \\
\infty \\
= \\
\geq\end{array}$ & 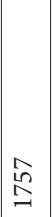 & 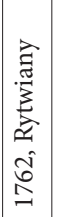 & $\begin{array}{l}3 \\
5 \\
5 \\
3 \\
0 \\
0 \\
0 \\
0\end{array}$ & 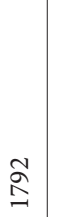 & & $\begin{array}{l}\infty \\
\stackrel{\infty}{\triangle} \\
\Xi \\
\Xi\end{array}$ \\
\hline 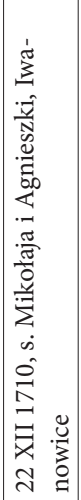 & 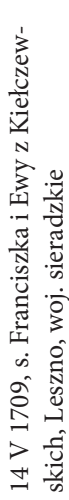 & 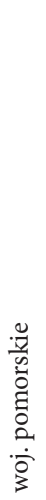 & 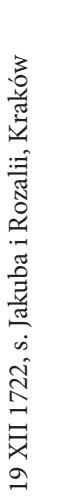 & 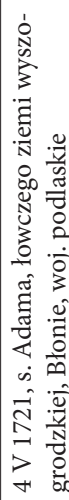 & 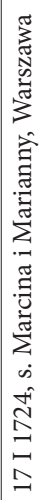 & 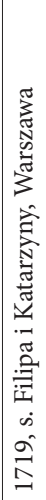 & 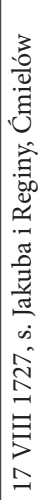 & 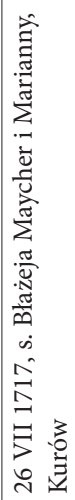 & 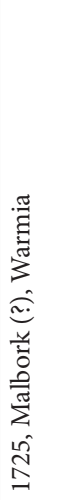 & 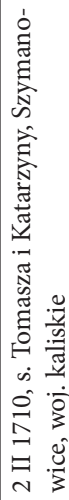 & 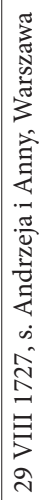 & 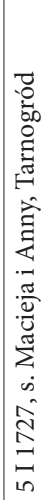 & 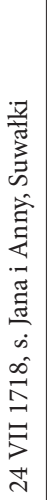 & 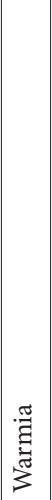 & 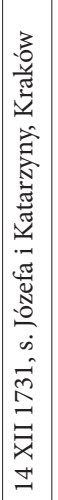 & 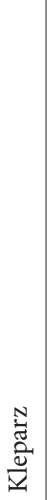 & 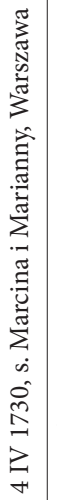 & 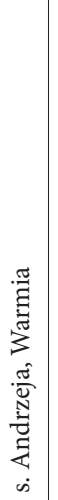 & 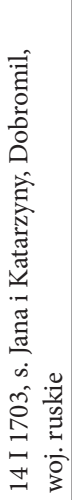 \\
\hline 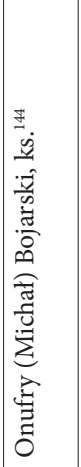 & 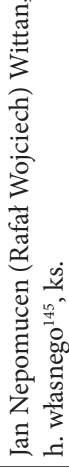 & 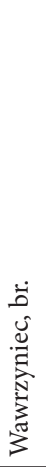 & 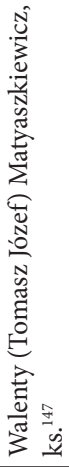 & 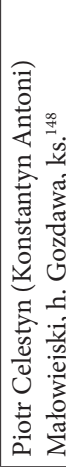 & 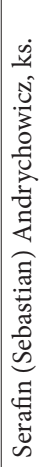 & 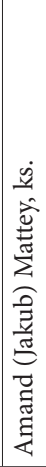 & 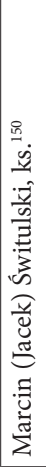 & 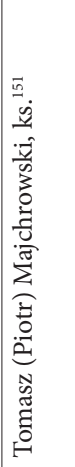 & 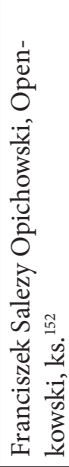 & 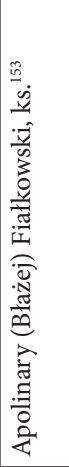 & 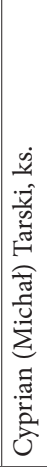 & 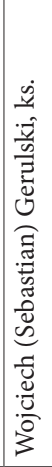 & 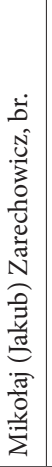 & 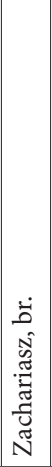 & 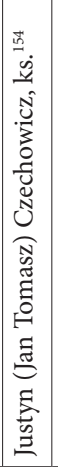 & 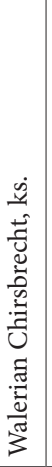 & 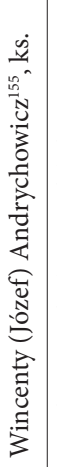 & 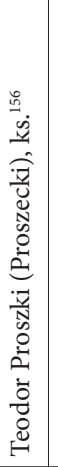 & 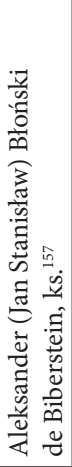 \\
\hline 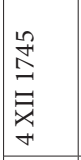 & $\begin{array}{l}\text { L } \\
\text { I } \\
\text { 孚 } \\
\text { N }\end{array}$ & 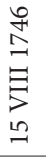 & 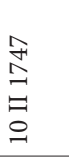 & 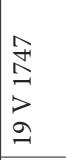 & 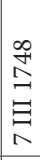 & 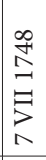 & 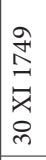 & 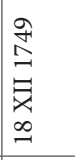 & 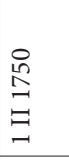 & 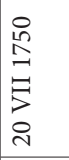 & 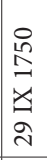 & 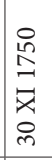 & 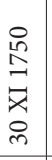 & 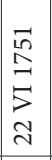 & 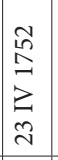 & 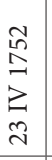 & $\begin{array}{l}\stackrel{N}{N} \\
\underset{\sim}{\sim} \\
\underset{\sim}{\sim} \\
\sim\end{array}$ & 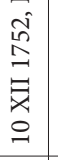 & $\begin{array}{l}\stackrel{n}{n} \\
\\
> \\
m\end{array}$ \\
\hline$\stackrel{\dot{m}}{m}$ & $\vec{m}$ & $\stackrel{\dot{m}}{m}$ & $\frac{\dot{m}}{m}$ & $\underset{m}{m}$ & $\bar{m}$ & $\vec{m}$ & $\vec{m}$ & $\frac{\infty}{m}$ & $\vec{m}$ & तें & $\overrightarrow{\widetilde{\sim}}$ & तె & $\stackrel{\widetilde{m}}{n}$ & $\tilde{m}$ & นn & స్ं & ते & 文 & సे \\
\hline
\end{tabular}




\begin{tabular}{|c|c|c|c|c|c|c|c|c|c|c|c|c|c|c|c|c|}
\hline ¿ి & in & $=$ & & $\ddot{n}$ & 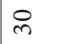 & లి & ले & i & ले & $a$ & 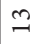 & $\stackrel{\sim}{\sim}$ & $\vec{\sim}$ & $\vec{\sim}$ & లె & \\
\hline 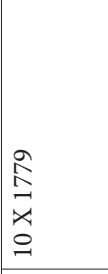 & 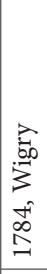 & 20 & & 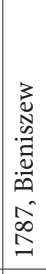 & 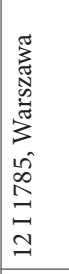 & 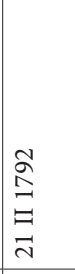 & 饮 & $\begin{array}{l}\stackrel{+}{\infty} \\
\stackrel{\text { I }}{\Xi} \\
\text { 当 }\end{array}$ & 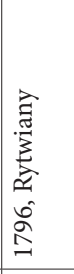 & $\begin{array}{l}8 \\
\stackrel{2}{2}\end{array}$ & 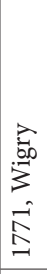 & 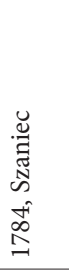 & 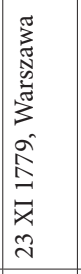 & 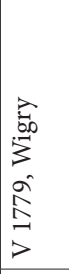 & হ̄ & 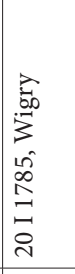 \\
\hline 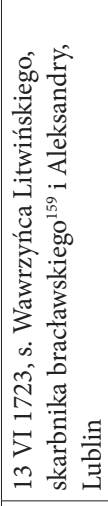 & 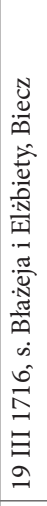 & 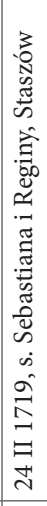 & 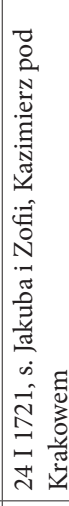 & 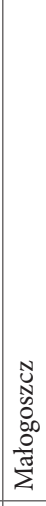 & 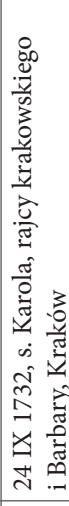 & 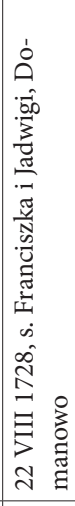 & . & 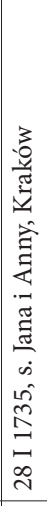 & 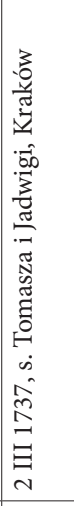 & 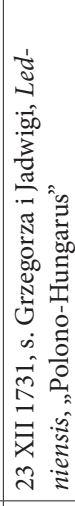 & 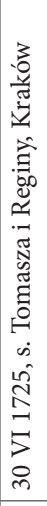 & 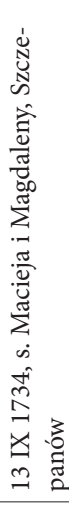 & 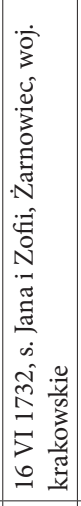 & 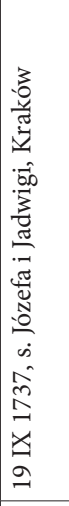 & 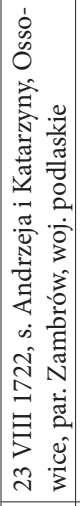 & 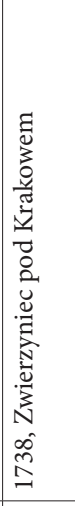 \\
\hline 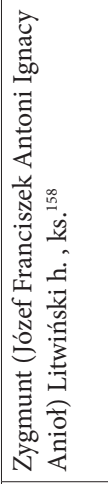 & 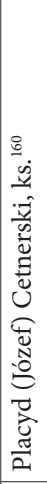 & 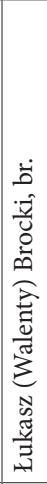 & 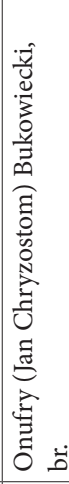 & 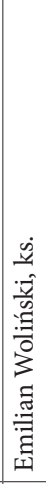 & 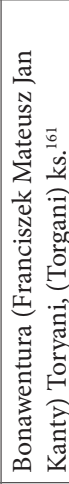 & 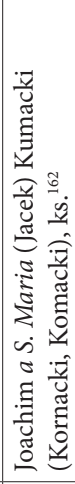 & $\begin{array}{l} \\
\\
: 0 \\
\vdots \\
\vdots \\
\vdots \\
0\end{array}$ & 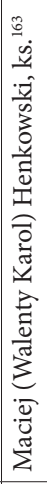 & 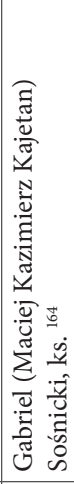 & 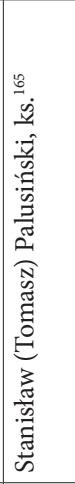 & 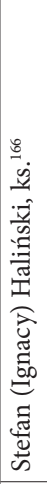 & 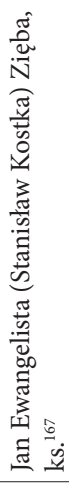 & 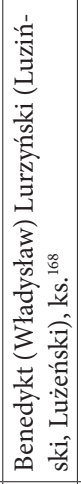 & 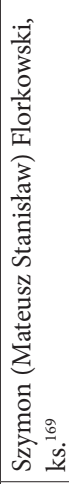 & 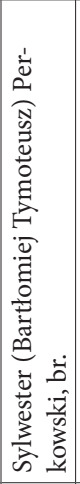 & 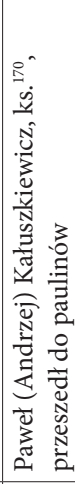 \\
\hline $\begin{array}{l}\hat{n} \\
\stackrel{3}{-} \\
\frac{1}{n}\end{array}$ & 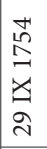 & 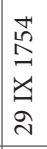 & 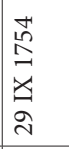 & 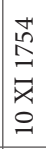 & 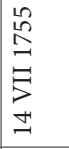 & 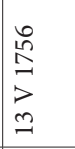 & 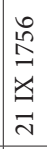 & $\begin{array}{l}\hat{i n} \\
\triangleq \\
\Xi \\
\vdots \\
\infty \\
\sim\end{array}$ & 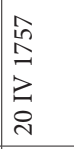 & $\begin{array}{l}\stackrel{i}{\stackrel{2}{2}} \\
\stackrel{-}{>} \\
\infty\end{array}$ & 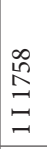 & $\begin{array}{l}\stackrel{\infty}{\stackrel{2}{n}} \\
\triangleq \\
=\end{array}$ & 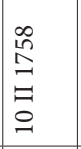 & 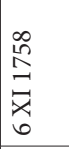 & $\begin{array}{l}\stackrel{\Omega}{\Lambda} \\
\text { 三 } \\
=\end{array}$ & 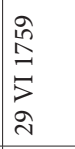 \\
\hline ల্ল & $\vec{m}$ & ले & $\dot{m}$ & ले & $\stackrel{m}{m}$ & లై & $\stackrel{\dot{m}}{m}$ & $\stackrel{\infty}{\infty}$ & लें & ஓे & $\overrightarrow{\text { Fे }}$ & भે & 户े & 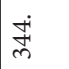 & 离 & 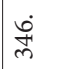 \\
\hline
\end{tabular}


Bielany - ulubione miejsce Krakowa...

\begin{tabular}{|c|c|c|c|c|c|c|c|c|c|c|c|c|c|c|}
\hline & $\infty$ & & $\pi \approx$ & $\infty$ & $=$ & ta & F & 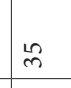 & i & & & \pm & 요 & $\approx$ \\
\hline & 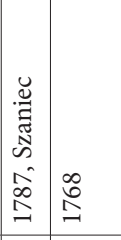 & & 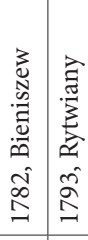 & 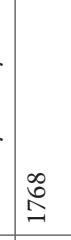 & & 舟 & 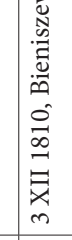 & 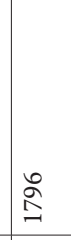 & $\underline{\underline{x}}$ & 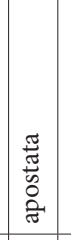 & & 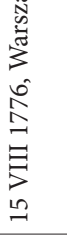 & 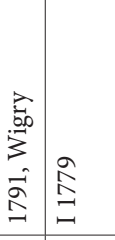 & 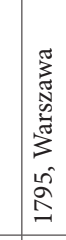 \\
\hline & 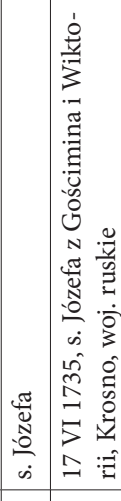 & 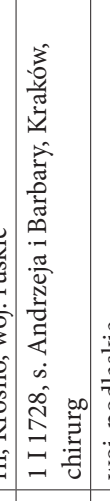 & 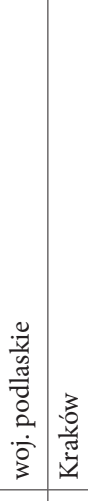 & 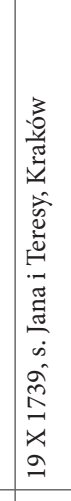 & 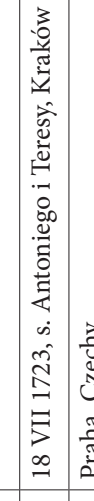 & 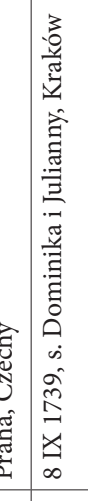 & 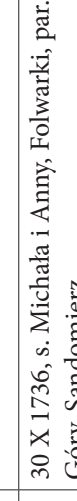 & 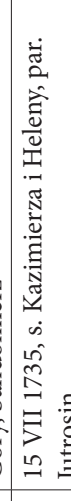 & 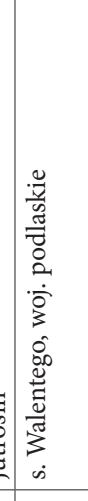 & & 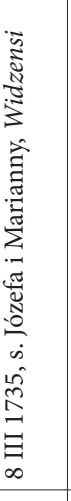 & 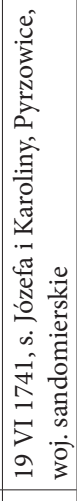 & 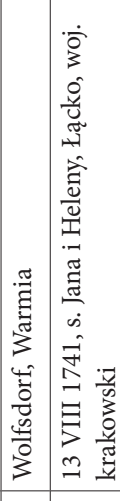 & 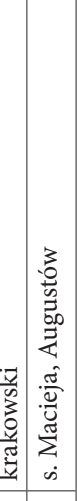 \\
\hline & 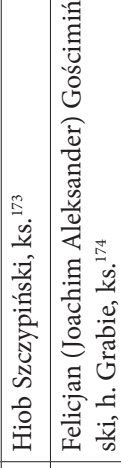 & 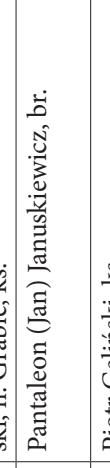 & 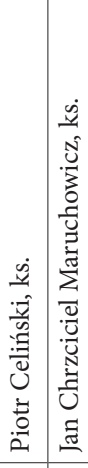 & & 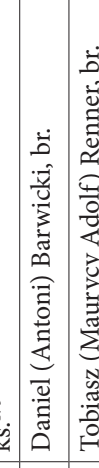 & & 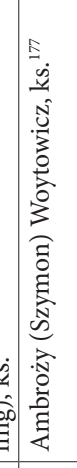 & 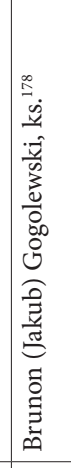 & 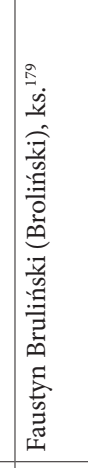 & 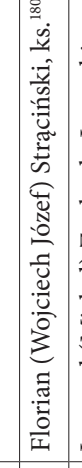 & & 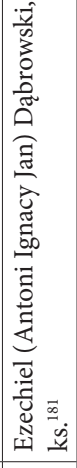 & 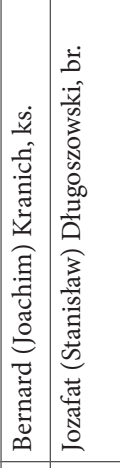 & 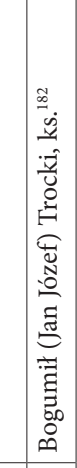 \\
\hline & 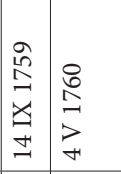 & $\begin{array}{ll}0 \\
0 \\
0 \\
7 \\
7\end{array}$ & 总 & 总 & 总: & 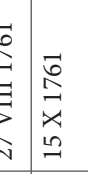 & 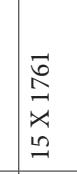 & 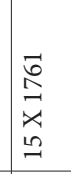 & 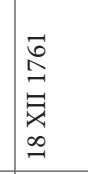 & & & 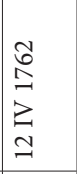 & 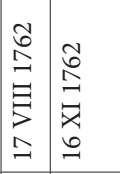 & 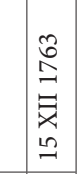 \\
\hline & 离 & : & 融要 & & 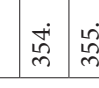 & & & 离 & 总 & & & 覂 & 帬 & \\
\hline
\end{tabular}




\begin{tabular}{|c|c|c|c|c|c|c|c|c|c|c|c|c|c|c|c|c|c|c|}
\hline- & ले & 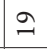 & $\ddot{\sim}$ & $\stackrel{12}{2}$ & & సి & $\stackrel{2}{2}$ & $\cong$ & $\stackrel{0}{2}$ & 6 & $\stackrel{0}{-1}$ & $\curvearrowright$ & กี & & F & $\stackrel{\infty}{\sim}$ & ৯े & $\stackrel{\sim}{\sim}$ \\
\hline 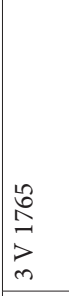 & 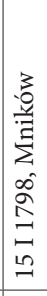 & $\stackrel{\infty}{\infty}$ & $\stackrel{\infty}{\stackrel{\infty}{\triangleq}}$ & 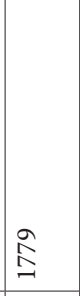 & & 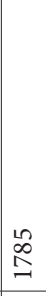 & $\stackrel{\infty}{\stackrel{\infty}{\beth}}$ & $\stackrel{\curvearrowright}{\stackrel{1}{~}}$ & $\begin{array}{l}\mathfrak{D} \\
\stackrel{D}{二}\end{array}$ & $\underset{N}{N}$ & $\stackrel{\infty}{\stackrel{\infty}{\beth}}$ & 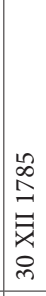 & 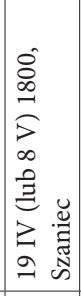 & 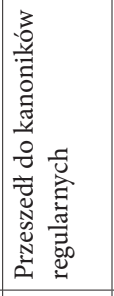 & $\underset{0}{\infty}$ & 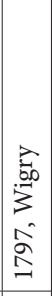 & 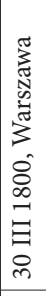 & స゙ \\
\hline 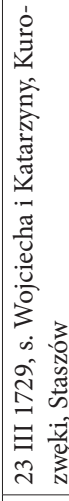 & 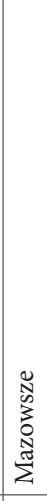 & 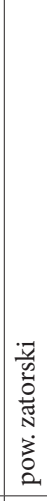 & 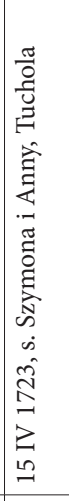 & 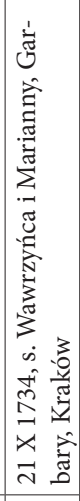 & 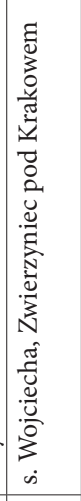 & 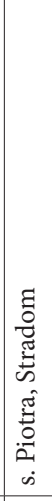 & 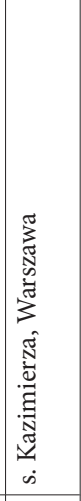 & 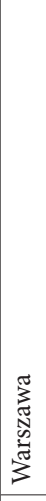 & 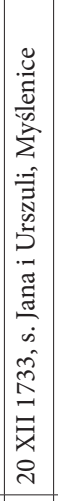 & 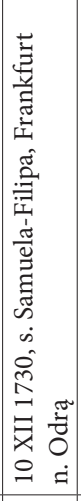 & 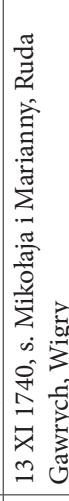 & 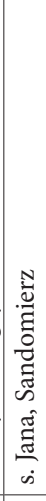 & 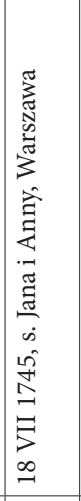 & 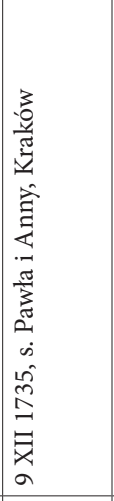 & 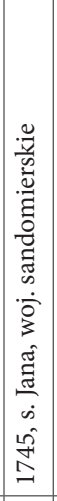 & 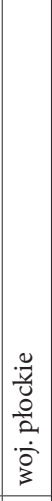 & 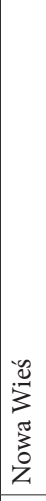 & \\
\hline 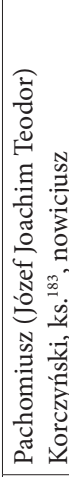 & 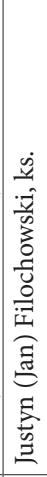 & 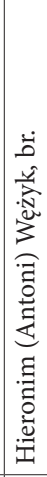 & 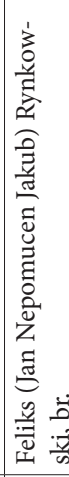 & 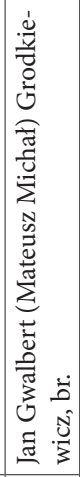 & 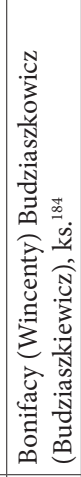 & 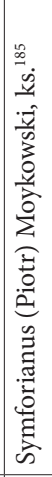 & 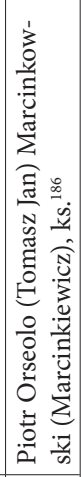 & 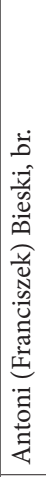 & 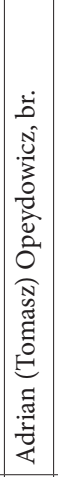 & 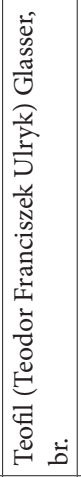 & 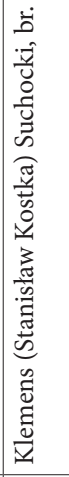 & 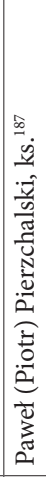 & 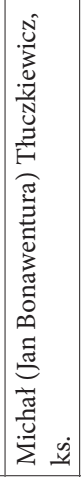 & 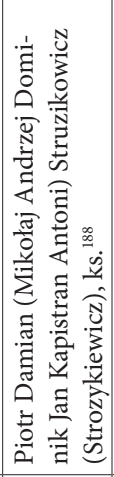 & 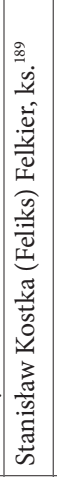 & 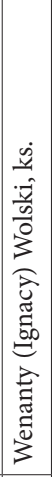 & 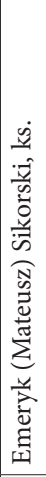 & \begin{tabular}{l}
$\overrightarrow{0}$ \\
\multirow{3}{0}{} \\
$\frac{0}{0}$ \\
$\frac{0}{2}$
\end{tabular} \\
\hline 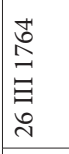 & 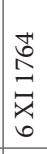 & 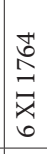 & 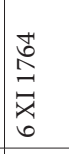 & 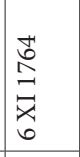 & 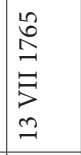 & 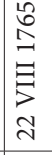 & $\begin{array}{l}\stackrel{\circ}{\circ} \\
\triangleq \\
\Xi \\
\vdots\end{array}$ & 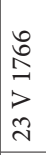 & 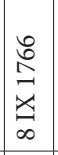 & 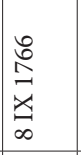 & 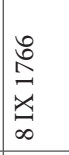 & 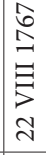 & 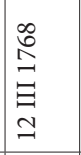 & 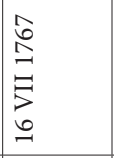 & $\begin{array}{l}\infty \\
0 \\
1 \\
\vdots \\
\bar{x} \\
\text { in }\end{array}$ & $\begin{array}{l}8 \\
\therefore \\
\vdots \\
z \\
=\end{array}$ & 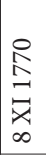 & 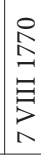 \\
\hline 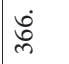 & i্ & $\begin{array}{l}\infty \\
0 \\
ల\end{array}$ & Dे & $\stackrel{i}{m}$ & 穴 & $\underset{m}{\mathbb{N}}$ & $\hat{m}$ & $\underset{m}{\stackrel{+}{m}}$ & 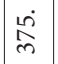 & $\stackrel{\dot{m}}{\stackrel{m}{n}}$ & 命 & $\frac{\infty}{\infty}$ & 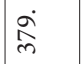 & $\begin{array}{l}\dot{\infty} \\
\dot{m}\end{array}$ & $\vec{\infty}$ & $\underset{\infty}{\infty}$ & $\begin{array}{c}\dot{D} \\
\infty \\
m\end{array}$ & 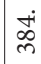 \\
\hline
\end{tabular}


Bielany - ulubione miejsce Krakowa...

\begin{tabular}{|c|c|c|c|c|c|c|c|c|c|c|c|c|c|c|c|c|c|c|c|c|}
\hline లి & $F$ & $\stackrel{\infty}{\rightarrow}$ & ల్ల & $q$ & m & $\approx$ & in & $\approx$ & $\stackrel{\infty}{\sim}$ & & $\exists$ & \pm & 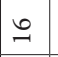 & 我 & $n$ & 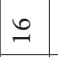 & ָ & & $\stackrel{\infty}{\sim}$ & $\exists$ \\
\hline $\begin{array}{l}\hat{\overrightarrow{5}} \\
\hat{3} \\
0 \\
0 \\
0 \\
0 \\
-1\end{array}$ & $\begin{array}{l}n \\
\infty \\
\infty \\
-1\end{array}$ & ડ̃ & $\underset{\stackrel{\infty}{\infty}}{\stackrel{0}{-}}$ & $\begin{array}{l}\infty \\
\infty \\
\infty \\
\rightarrow\end{array}$ & 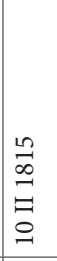 & 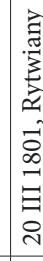 & 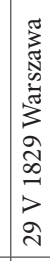 & $\begin{array}{l} \\
\cong \\
\infty \\
\infty \\
\geq \\
z \\
z\end{array}$ & 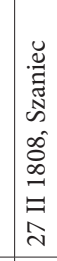 & & $\begin{array}{l}\infty \\
\infty \\
\infty \\
0 \\
0 \\
\stackrel{2}{2}\end{array}$ & 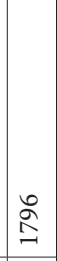 & 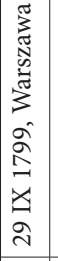 & 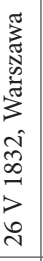 & 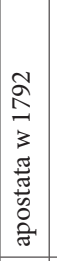 & 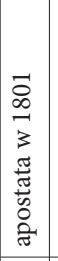 & & & . & \\
\hline 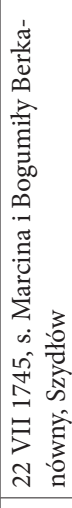 & 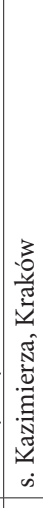 & & 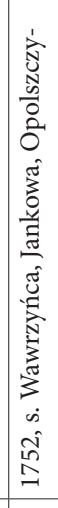 & 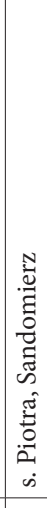 & 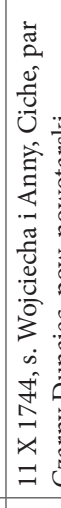 & 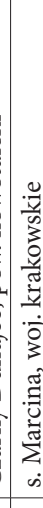 & 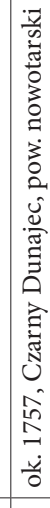 & 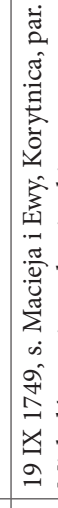 & 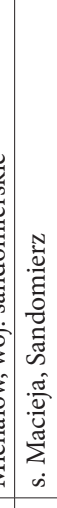 & 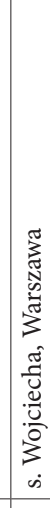 & 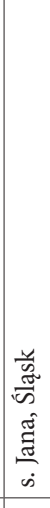 & 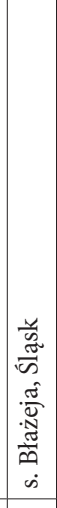 & 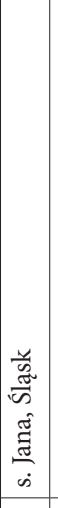 & 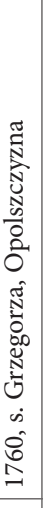 & & 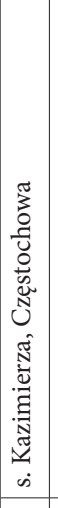 & 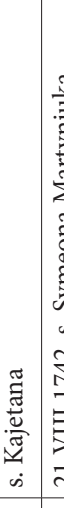 & 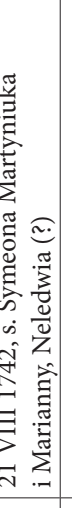 & & \\
\hline 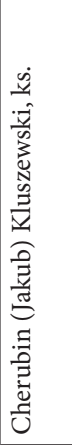 & 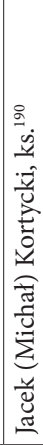 & 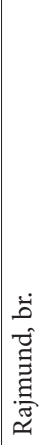 & 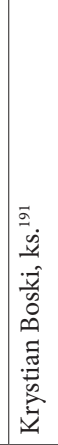 & 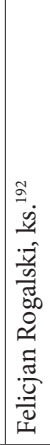 & 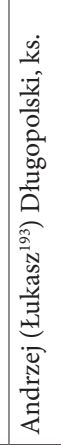 & 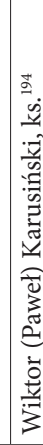 & 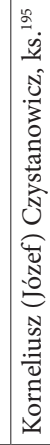 & 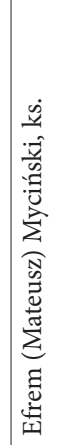 & 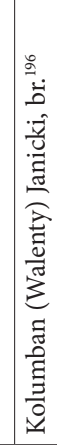 & 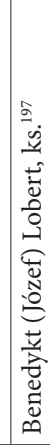 & 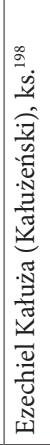 & 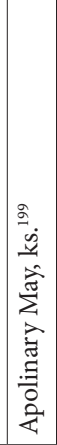 & 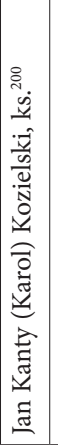 & 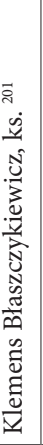 & 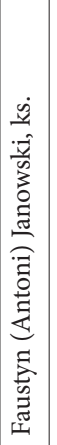 & 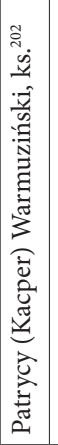 & 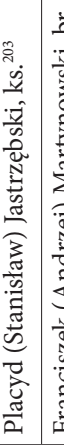 & 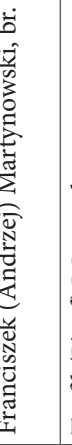 & 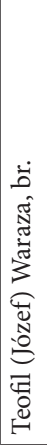 & 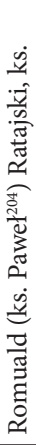 \\
\hline 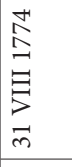 & 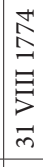 & 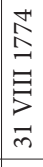 & 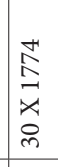 & 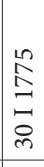 & 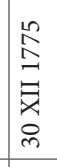 & 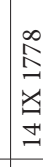 & 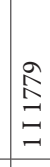 & 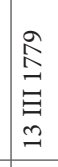 & 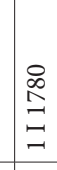 & $\begin{array}{l}\vec{\infty} \\
\stackrel{2}{\vec{z}} \\
\vec{z} \\
0\end{array}$ & 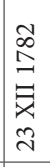 & 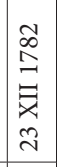 & 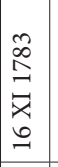 & 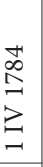 & 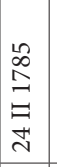 & 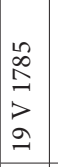 & 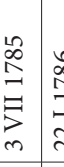 & & 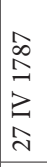 & \\
\hline$\stackrel{\substack{\infty \\
m}}{\infty}$ & $\begin{array}{l}\infty \\
\infty \\
ల\end{array}$ & {$\left[\begin{array}{c}\infty \\
\infty \\
m\end{array}\right.$} & $\begin{array}{l}\infty \\
\infty \\
m\end{array}$ & 㐫 & 今ं & $\mathrm{m}$ & mे & ळ్ & స్ & $m$ & $m$ & 命 & {$\left[\begin{array}{c}\infty \\
\tilde{m}\end{array}\right]$} & बे & \& & $\overrightarrow{\vec{a}}$ & ¿̇ं & $\stackrel{8}{4}$ & ơ & \\
\hline
\end{tabular}




\begin{tabular}{|c|c|c|c|c|c|c|c|c|c|c|c|c|c|c|c|c|c|c|c|c|c|}
\hline & & $\vec{\lambda}$ & & & & $\triangleq$ & & 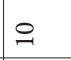 & & & & mे & $\tilde{m}$ & & $\vec{F}$ & ते & iे & $\vec{m}$ & $\tilde{N}$ & $\stackrel{20}{\sim}$ & $\stackrel{\infty}{\sim}$ \\
\hline & 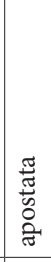 & $\underset{\infty}{\stackrel{\infty}{-\infty}}$ & & & & 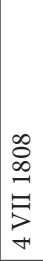 & & 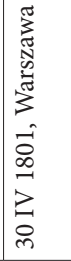 & & 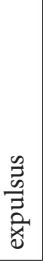 & & 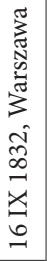 & $\begin{array}{l}\underset{1}{\infty} \\
\underset{\sim}{-}\end{array}$ & & $\begin{array}{c}\infty \\
\infty \\
\infty \\
-1\end{array}$ & 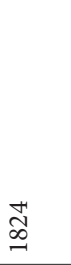 & 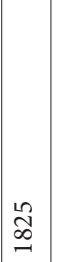 & 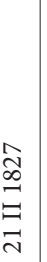 & 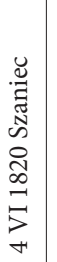 & 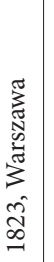 & 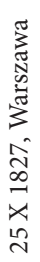 \\
\hline & & & & & 离 & & 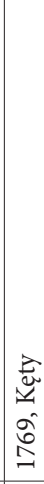 & 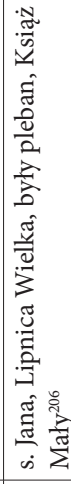 & & & & 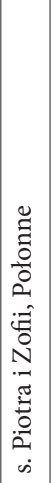 & 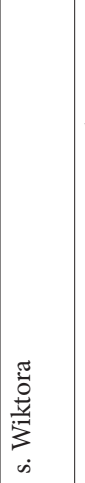 & 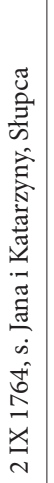 & & $\frac{\frac{\pi}{7}}{\dot{s}}$ & 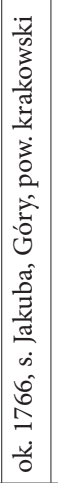 & 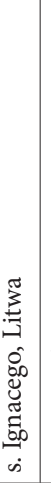 & |. & 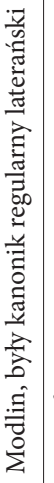 & 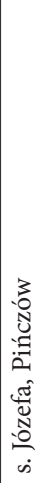 \\
\hline 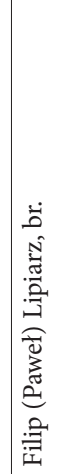 & 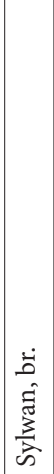 & 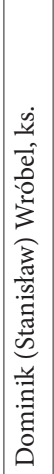 & 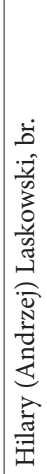 & 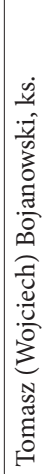 & 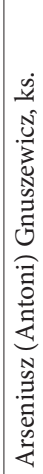 & 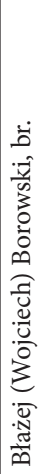 & 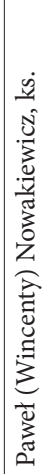 & 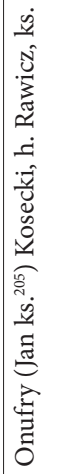 & 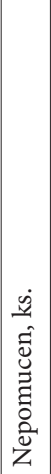 & 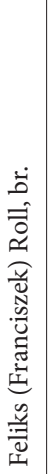 & 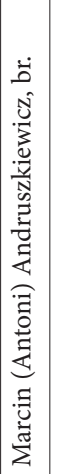 & 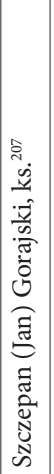 & 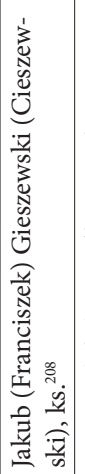 & 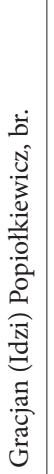 & 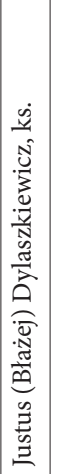 & 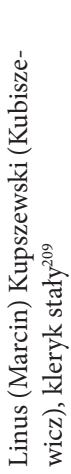 & 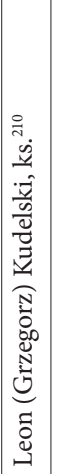 & 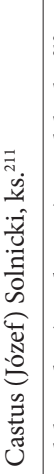 & 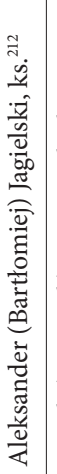 & 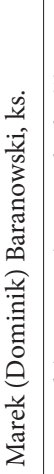 & 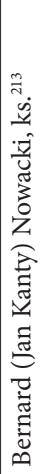 \\
\hline 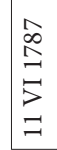 & 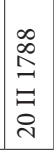 & $\begin{array}{l}\stackrel{\alpha}{2} \\
\stackrel{x}{x} \\
\stackrel{\lambda}{\sim}\end{array}$ & 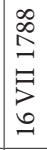 & 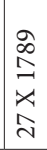 & $\begin{array}{l}\sqrt{2} \\
\stackrel{2}{5} \\
\text { a }\end{array}$ & 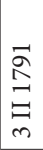 & $\begin{array}{l}\vec{\lambda} \\
\overrightarrow{3} \\
\overrightarrow{3} \\
\text { aे }\end{array}$ & $\begin{array}{l}\overrightarrow{\widehat{A}} \\
\vec{B} \\
\vec{\forall}\end{array}$ & 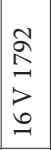 & 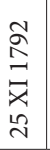 & 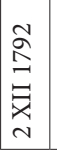 & 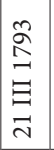 & 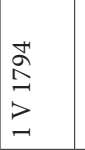 & 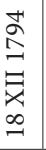 & 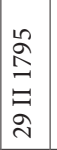 & 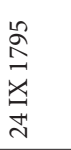 & 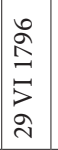 & 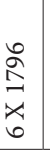 & 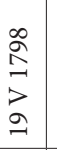 & 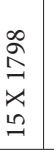 & 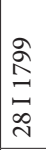 \\
\hline 字 & 宰 & 文 & 过 & F & $\bar{F}$ & $\underset{f}{f}$ & $\stackrel{m}{F}$ & $\stackrel{\vec{F}}{F}$ & $\begin{array}{l}\stackrel{10}{7} \\
F\end{array}$ & $\stackrel{\dot{\sigma}}{\neq}$ & $\vec{F}$ & $\begin{array}{l}\infty \\
\Rightarrow \\
\Rightarrow\end{array}$ & $\vec{\gamma}$ & ఫิ & $\overrightarrow{\vec{\gamma}}$ & İ & శึ่ & $\stackrel{\leftrightarrow}{\sharp}$ & $\ddot{\not}$ & $\stackrel{\leftrightarrow}{4}$ & 今े \\
\hline
\end{tabular}




\section{Przypisy do tabeli}

1 W roku 1617 - pierwszy przeor eremu bielańskiego.

2 Gdy nie wskazano miejsca przy dacie śmierci, to nastąpiła ona w klasztorze bielańskim.

3 Był przeorem w latach 1618-1619, po czym wyjechał do Włoch.

4 Przyjął święcenia subdiakonatu [dalej Sd.] 23 XII 1606, diakonatu [dalej: D.] 19 XII 1608, prezbiteratu [dalej: P.] 25 II 1611. Gdy nie wskazano miejsca święceń, to udzielone zostały w Krakowie.

5 Jeśli nie wskazano miejscowości, profesja złożona została w klasztorze bielańskim.

6 W roku 1621 przybył na Bielany, a w 1623 opuścił je, udając się do klasztoru w Rytwianach - R. Skiba, Życie pustelnicze kamedułów w Bieniszewie, „Kronika Wielkopolski”, 2001, nr 4, s. 75; Monografje zakonów, „Przegląd Katolicki”, R. 4, 1866, nr 18, s. 282-283; nr 21, s. 332-333.

7 O. Kazimierz był zapewne pierwszym zmarłym kamedułą w eremie na Bielanach.

8 Zmarł in odore sanctitatis.

9 P. 1622 Monte Corona.

10 Przebywał w latach 1624 do 1628 i 1629-1630 na Bielanach, gdzie malował obrazy do ołtarzy w kościele Wniebowzięcia NMP, Koronacji NMP, oraz marszałka Wolskiego. - L. Zarewicz, Klasztor kamedułów na Kahlenbergu pod Wiedniem. (Przyczynek do Sobiescianów), „Kalendarz Katolicki Krakowski”, R. 4, 1884, s. 78; A. Małkiewicz, Twórczość malarza-kameduły o. Wenantego z Subiaco w świetle najnowszych badań, „Folia Historica Cracoviensia”, T. 11, 2005, s. $117-132$.

11 BCzart, rkps 1820 IV, s. 131.

12 W źródłach nazwany został „pater praestantissimus et doctissimus”, 1639 - pierwszy wikariusz generalny kamedułów polskich.

13 E. Ozorowski bp, Szober Wojciech ( $† 1664)$, kameduła, autor dysertacji z prawa kanonicznego, [w:] Słownik polskich teologów katolickich, t. 4, red. H. E. Wyczawski OFM, Warszawa 1983, s. 279.

14 Obecny na Bielanach w 1631 roku.

15 Bratanek Anny Lubomirskiej z Ruszczy, kasztelanowej wojnickiej.

16 Syn Jana sekretarza Zygmunta III i Reginy Gutteterównej, a wnuk sławnego prawnika Jana Kirszteina.

17 Był pierwszym przeorem klasztoru Montis Pacis w Pożajściu; zmarł w opinii wielkiej świątobliwości.

18 D. 16 III 1647.

19 D. 21 I 1648, P. 20 II 1649.

20 Zmarł w opinii świętości.

21 Święcenia niższe [dalej: Min.] 28 III 1648.

22 Subdiakonat 15 VI 1647.

23 Min. 15 VI 1647; Sd. 20 XII 1653.

24 Sd. 20 XII 1653.

25 Zmarł w opinii świętości. 
26 Zmarł jako rekluz w opinii świętości. W latach 1671-1673 był wizytatorem przy przełożonym generalnym na Monte Corona - P. T. Lugano, La Congregazione camaldolese degli Eremiti di Montecorona. Dalle origini ai nostri tempi. Con una introduzione sulla vita eremitica prima e dopo san Romualdo, [w:] Monografie di storia benedettina, t. 1, Frascati 1908, s. 514; L. Zarewicz, O. Bernard Szymoński. (Typ polskiego ascety), „Kalendarz Katolicki Krakowski”, R. 9, 1889, s. 85-89; Monografje zakonów, „Przegląd Katolicki”, R. 4, 1866, nr 22, s. 344.

27 Zmarł w opinii świętości.

28 Min. 21 IX 1658; Sd. 20 XII 1659; D. 18 XII 1660; P. 24 IX 1661.

29 Zmarł w opinii świętości.

30 Sd. 21 IX 1658.

31 Sd. 24 IX 1661.

32 M. Czapińska, Mitkowski Władysław, imię zakonne Paweł (1619-1661), [w:] Polski słownik biograficzny, t. 21, red. E. Rostworowski, Wrocław 1976, s. 384; J. Szczepaniak, Katalog duchowieństwa diecezjalnego zestawiony na podstawie krakowskich ksiąg święceń (1649-1789): J-M, Kraków 2008, s. 729.

33 Min. 24 IX 1661.

34 Żołnierz wojsk skonfederowanych za czasów króla Jana Kazimierza.

35 D. 24 IX 1667, P. 21 IX 1669.

36 Min. 19 XII 1665, D. 17 III 1668.

37 Min. 19 XII 1665.

38 Min. 18 IX 1666.

39 Sd. 17 III 1668.

40 Min. 17 XII 1667.

41 Min. 17 XII 1667, Sd. 21 IX 1669.

42 Min. 20 IX 1670.

43 Min. 12 III 1672.

44 Min. 12 III 1672.

45 Min. 12 III 1672, Sd. 18 III 1673.

46 Min. 12 III 1672.

47 Min. 18 III 1673, D. 21 IX 1675, P. 19 IX 1676.

48 Sd. 18 III 1673.

49 Sd. 21 IX 1675.

$50 \quad$ Min. 21 IX 1675.

51 Min. 13 III 1677.

52 P. 19 IX 1682.

53 P. 1 VI 1697.

54 Min. 3 III 1691.

55 Min. 3 III 1691, Sd. 7 II 1693. 
56 Sd. 3 III 1691, D. 2 IX 1692.

57 Min. 3 III 1691, Sd. 7 II 1693.

58 Min. 29 II 1692, Sd. 7 II 1693, P. 1 XI 1694.

59 Min. 29 II 1692.

60 Min. 29 II 1692.

61 D. 12 II 1698, P. 14 III 1699.

62 Sd. 16 III 1698.

63 Min. 12 II 1698, Sd. 14 III 1699.

64 Sd. 5 VI 1700, D. 21 V 1701, P. 6 III 1703.

65 Min. 16 III 1698, Sd. 14 III 1699, D. 22 XII 1703.

66 Min. 14 III 1699.

67 Min. 5 VI 1700, Sd. 17 XI 1701; D 19 III 1707.

68 Towarzysz z chorągwi wojewody kaliskiego.

69 Min. 24 III 1703.

70 Min. 22 XII 1703.

71 Min. 28 III 1705.

72 Sd. 27 II 1706; P. 21 IX 1709.

73 Min. 28 III 1705; D 19 III 1707.

74 Min. 28 III 1705, Sd. 28 XII 1706; P. 21 IX 1709.

75 Sd. 18 VI 1707.

76 Zapewne Lagisze, pow. będziński, woj. katowickie.

77 Min. 18 VI 1707; Sd. 13 VII 1708; D. 14 VI 1708; P. 15 VII 1708.

78 D. 20 IX 1710, P. 12 V 1710.

79 Sd. 20 IX 1710.

80 Zmarł w opinii świętości.

81 Min. 20 IX 1710.

$82 \quad$ Min. 19 IX 1711.

83 Min. 19 IX 1711; Sd. 21 XII 1721.

84 Min. 19 IX 1711; P. 24 IX 1712.

85 Sd. $21 \mathrm{~V} 1712$.

86 Sd. $21 \mathrm{~V} 1712$.

87 Min. 15 VII 1700, Sd. 17 V 1704, D. 13 VII 1704, P. 26 VII 1704 - J. Szczepaniak, Katalog duchowieństwa diecezjalnego zestawiony na podstawie krakowskich ksiąg święceń (1649-1789): N-S, Kraków 2008, s. 838.

88 Min. 19 IX 1711; Sd. 24 IX 1712.

89 Min. 24 IX 1712; Sd. 23 IX 1713; D. 24 VI 1714.

90 Min. 23 IX 1713.

91 Służył w chorągwi husarskiej Jerzego Stanisława Dzieduszyckiego. 
92 D. 21 IX 1715.

93 Towarzysz cohortis loricatae koniuszego koronnego Jerzego Stanisława Dzieduszyckiego.

94 „Externae militiae major”.

95 Min. 23 IX 1713; Sd. 3 VI 1714, D. 8 VII 1714,

96 Dyspensa nuncjusza apostolskiego 27 VII 1712 - Acta Nuntiaturae Polonae, t. 43: Benedictus Odescalchi-Erba (1711-1713), ed. I. A. Gierowski, I. Kopiec, Cracoviae 2009, s. 248, nr 256.

97 Min. 28 VIII 1715.

98 Min. 28 VIII 1715.

99 Min. 28 VIII 1715; D. 2 IV 1718, P. 17 XII 1718.

100 Min. 28 VIII 1715; Sd. 18 IX 1717; P. 17 XII 1718.

101 Min. 28 VIII 1715; P. 21 IX 1720.

102 Min. 22 VII 1717.

103 Chorąży znaku pancernego podstolego koronnego Michała Kazimierza Lubomirskiego.

104 Min. 20 II 1717, Sd. 4 III 1719.

105 Min. 20 II 1717.

106 Min. 20 II 1717.

107 Min. 22 VII 1717.

108 Sd. 4 III 1719.

109 Sd. 4 III 1719.

110 Sd. 4 III 1719.

111 Sd. 21 XII 1720, D. 21 XII 1721.

112 Święcenia kapłańskie otrzymał w katedrze włocławskiej z rąk biskupa pomocniczego Wojciecha Ignacego Bardzińskiego w dniu 18 X 1716 roku.

113 Sd. $30 \mathrm{~V} 1722$.

114 Min. 21 XII 1721, D. 24 II 1725, P. 17 III 1725.

115 Min. 20 XII 1722.

116 Min. 20 XII 1722.

117 Min. 21 XII 1721.

118 Min. 20 XII 1722.

119 Były prepozyt kościoła „Skrzynens.”

120 Min. 23 XI 1725; Sd 20 XII 1727; P 23 IX 1730.

121 Min. 20 XII 1727.

122 Chorąży ziemi dobrzyńskiej.

123 Min. 18 IX 1728.

124 Min. 18 IX 1728.

125 Min. 18 IX 1728; Sd. 19 V 1731.

126 P. 22 IX 1736.

127 Był penitencjarzem w katedrze gnieźnieńskiej i kanonikiem kapituły kolegiackiej św. Jerzego w Gnieźnie. 
128 Zmarł w opinii świętości.

129 Min. 26 V 1736.

$130 \quad$ Sd. 22 IX 1736.

131 Min. 10 XII 1739, Sd. 18 III 1741.

132 Min. 10 XII 1739.

133 D. 29 VI 1745; P. 18 IX 1745.

134 Określany był jako chorąży lubelski, ale nie jest odnotowany na tym stanowisku - Urzędnicy województwa lubelskiego XVI-XVIII wieku. Spisy, oprac. W. Kłaczewski, W. Urban, [w:] Urzędnicy dawnej Rzeczypospolitej XII-XVIII wieku. Spisy, red. A. Gąsiorowski, t. 4: Małopolska (Województwa krakowskie, sandomierskie i lubelskie), z. 4, Kórnik 1991, s. 19.

135 D. 18 IX 1745.

136 Były kleryk krakowskiego seminarium na Stradomiu - J. Szczepaniak, Katalog alumnów seminarium stradomskiego. (1732-1800), [w:] Bibliotheca Collectanea Historica, t. 3, Kraków 2006, s. 120.

137 D. 29 VI 1745; P. 18 IX 1745.

138 D. 18 IX 1745.

139 P. 19 XII 1750.

140 P. 19 XII 1750.

141 Zmarł w opinii świętości.

142 P. 14 III 1750.

143 Sd. 27 V 1747.

144 Sd. 27 V 1747.

145 Był opatem norbertanów sądeckich w latach 1743-1745 - Wypisy źródłowe do biografii polskich biskupów i opatów z czasów Rzeczypospolitej Obojga Narodów oraz niewoli narodowej doby zaborów (XVI-XIX w.), [cz. 5], oprac. K. R. Prokop, „Archiwa, Biblioteki i Muzea Kościelne”, t. 87, 2007, s. 132-133.

146 Zmarł w opinii świętości.

147 Min. 23 XII 1747; Sd. 30 III 1748.

148 Min. 23 XII 1747; Sd. 30 III 1748.

149 „Pater observantissimus” - W. Murawiec OFM, Andrychiewicz (Andrychowicz) Serafin Sebastian († 1773), kameduła, historyk swego zakonu, [w:] Słownik polskich teologów katolickich, t. 1, red. H. E. Wyczawski OFM. Warszawa 1981, s. 50-51.
150 Min. 19 IX 1750.
$151 \quad$ Min. 19 IX 1750.
152 Min. 19 IX 1750.
153 Min. 19 IX 1750.
154 D. 18 IX 1756; P. 17 XII 1757.
155 Brat rodzony Serafina.
156 D. 24 IX 1757; P. 18 II 1758.

157 Min. 22 XII 1753; Sd. 30 III 1754; D. 13 IV 1754; 8 VI 1754. 
158 Min. 22 XII 1753; Sd. 30 III 1754; P. 13 III 1756.

159 Nieznany.

160 Sd. 1 III 1760; D. 22 III 1760.

161 D. 18 III 1759.

162 Min. 26 III 1757.

163 Min. 17 XII 1757; P. 27 III 1762.

164 Min. 17 XII 1757; Sd. 20 V 1758.

165 Min. 20 V 1758.

166 D. 19 XII 1761; 10 IV 1762.

167 D. 6 III 1762; P. 27 III 1762.

168 Min. 14 IV 1759.

169 Min. 14 IV 1759; Sd. 21 IX 1759; P. 2 IV 1763.

170 Min. 21 IX 1759; D. 28 V 1763; P. 24 IX 1763.

171 Min. 21 IX 1759.

172 Zmarł w opinii świętości.

173 Min. 21 IX 1759.

174 Sd. 16 V 1761; D. 24 IX 1763; P. 7 IV 1764.

175 D. 17 III 1764; P. 7 IV 1764.

176 Min. 5 VI 1762; Sd. 24 V 1766; D. 20 IX 1766; P. 4 IV 1767.

177 Min. 5 VI 1762; Sd. 22 IX 1764; D. 17 IX 1765; P. 4 III 1767.

178 Min. 5 VI 1762.

179 Min. 5 VI 1762.

180 Min. 5 VI 1762.

181 Min. 5 VI 1762; P. 4 III 1767.

182 Min. 16 VI 1764; Sd. 22 IX 1764; D. 25 IX 1773.

183 Min. 16 VI 1764; Sd. 22 IX 1764.

184 Min. 25 V 1766.

185 Min. 25 V 1766; D. 28 V 1768, P. 28 III 1771.

186 Min. 25 V 1766; Sd. 4 III 1767, P. 2 IV 1774.

187 Min. 4 III 1767.

188 Min. 4 III 1767; Sd. 19 XII 1772, D. 6 III 1773.

189 Min. 20 V 1769.

190 Sd. 23 IX 1775.

191 Sd. 18 IX 1779, P. 19 II 1780.

192 Sd. 23 IX 1775.

193 Były pleban w Podegrodziu, był kapłanem diecezji krakowskiej od 1769 roku. J. Szczepaniak, Katalog duchowieństwa diecezjalnego zestawiony na podstawie krakowskich ksiag święceń (1649-1789), A-I, Kraków 2008, s. 198; J. Szczepaniak, Katalog alumnów seminarium 
zamkowego w Krakowie.(1677-1801), [w:] Bibliotheca Collectanea Historica, t. 2, Kraków 2003/2004, s. $82-83$.

194 Min. 16 III 1782, Sd. 6 III 1784, D. 19 II 1785, P. 11 III 1786.

195 „Columna religionis in angustia sui temporis calamitosi”.

196 Min. 5 IV 1783, Sd. 19 IV 1783.

197 Min. 5 VI 1784, D. 23 XII 1786.

198 Min. 6 III 1784.

199 Min. 6 III 1784.

200 Min. 18 XII 1784.

201 Min. 18 XII 1784.

202 Min. 24 IX 1785.

203 Min. 24 IX 1785.

204 Były pleban parafii Borzęcinek w diecezji krakowskiej - J. Szczepaniak, Spis prepozytów i plebanów diecezji krakowskiej (XVIII w.), Kraków 2008, s. 343; Tenże, Katalog alumnów seminarium stradomskiego..., dz. cyt., s. 82.

205 Min. 21 II 1750, Sd. 10 IV 1751, D. 13 VI 1751, P. 10 X 1751.

206 J. Szczepaniak, Spis prepozytów i plebanów diecezji krakowskiej (XVIII w.), Kraków 2008, s. 83 .

207 Min. 26 V 1793.

208 Min. 20 IX 1794, Sd. 21 III 1795.

209 Min. 24 IX 1796.

210 Min. 24 IX 1796, D. 22 IX 1798, P. 22 XII 1798.

211 Sd. 29 III 1800.

212 Sd. 29 III 1800.

213 Sd. 21 III 1801, D. 5 IV 1802.

\section{Źródła}

[S. Andrychowicz], Series reverendorum patrum et fratrum eremitarum Camedulensium congregationis Montis Coronae tam eremi Montis Argentini supra Cracoviam in Polonia quam eremi Montis Pacis supra Coronam in Lithuania Professorum vivorum et vita defunctorum conscripta. Viennae Austriae [ok. 1760], ex typ. Gheleniana, s. 3-28.

Monastica Polonorum. Fontes et studia, red. A. M. Wyrwa, R. Witkowski, t. 1: Wizytacje klasztoru cysterek w Owińskach. Nekrolog klasztoru cystersów w Paradyżu. Katalogi monastyczne, Warszawa 2009, s. 195-217. 
L. Zarewicz, Zakon kamedułów jego fundacye i dziejowe wspomnienia w Polsce i na Litwie. Przeważnie według źródeł rękopiśmiennych archiwu OO. Kamedułów w Bielanach przy Krakowie skreślił [...], Kraków 1871, s. 97-123.

Księgi egzaminów do święceń w diecezji krakowskiej z lat 1572-1614, wyd. Z. Pietrzyk, Kraków 1991.

Archiwum Kurii Metropolitalnej w Krakowie, LOrd., t. 4: Liber ordinatorum consecrationis ecclesiarum, capellarum, altarium, portatilium ac calicium per [...] Nicolaum Oborski 1646-1672.

Tamże, LOrd., t. 5: Liber ordinatorum consecrationis ecclesiarum, capellarum, altarium, immobilium, portatilium ac calicium per [...] Nicolaum Oborski officialem generalem Cracoviensem 1673-1693.

Archiwum Kamedułów w Krakowie, rkps Professio Fratrum 1577-1800. 